ORP-53933

Revision 0

\title{
Development of High Waste-Loading HLW Glasses for High Bismuth Phosphate Wastes, VSL-12R2550-1, Rev. 0
}

Prepared for the U.S. Department of Energy Assistant Secretary for Environmental Management

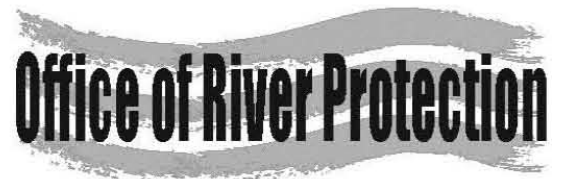

P.O. Box 450

Richland, Washington 99352 
ORP-53933

Revision 0

\section{Development of High Waste-Loading HLW Glasses for High Bismuth Phosphate Wastes, VSL-12R2550-1, Rev. 0}

A. A. Kruger

Department of Energy - Office of River Protection

I. L. Pegg

The Catholic University of America
H. Gan

The Catholic University of America

W. K. Kot

The Catholic University of America

Date Published

October 2012

Prepared for the U.S. Department of Energy

Assistant Secretary for Environmental Management

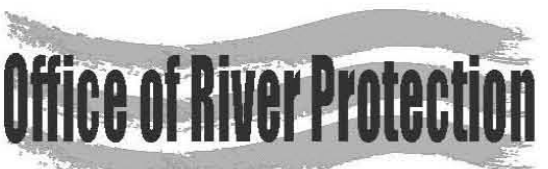

P.O. Box 450

Richland, Washington 99352

By Janis D. Aardal at 1:19 pm, Dec 13, 2012

Release Approval

Date 
ORP-53933

Revision 0

TRADEMARK DISCLAIMER

Reference herein to any specific commercial product, process, or service by tradename, trademark, manufacturer, or otherwise, does not necessarily constitute or imply its endorsement, recommendation, or favoring by the United States Government or any agency thereof or its contractors or subcontractors.

This report has been reproduced from the best available copy.

Printed in the United States of America 
VSL-12R2550-1

\title{
Final Report
}

\section{Development of High Waste-Loading HLW Glasses for High Bismuth Phosphate Wastes}

\author{
prepared by
}

\author{
Hao Gan, Wing K. Kot, and Ian L. Pegg \\ Vitreous State Laboratory \\ The Catholic University of America \\ Washington, DC 20064

$$
\text { for }
$$

EnergySolutions, Federal EPC, Inc.

Columbia, MD 21046

and

U.S. Department of Energy

Office of River Protection

Richland, WA 99352

August 13, 2012

Rev. $0,9 / 20 / 12$ 
The Catholic University of America

Vitreous State Laboratory
Development of High Waste Loading HLW Glasses for High Bismuth Phosphate Wastes Final Report, VSL-12R2550-1, Rev. 0
Document Title:

Document Number and Revision:

Issue Date:

Performing Organization: Vitreous State Laboratory, The Catholic University of America

Test Plan:
Development of High Waste-Loading HLW Glasses for High Bismuth Phosphate Wastes

\author{
VSL-12R2550-1, Rev. 0
}

$9 / 20 / 12$ HLW Glasses for High Bismuth Phosphate Wastes, VSL-12T2550-1, Rev. 0

This report describes the results of testing specified by the above Test Plan. The work was performed in compliance with the quality assurance requirements specified in the Test Plan. Results required by the Test Plan are reported. The test results and this report have been reviewed for correctness, technical adequacy, completeness, and accuracy.

I.L. Pegg:

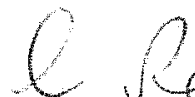

VSL Program Director/Principal/I I ivestigator

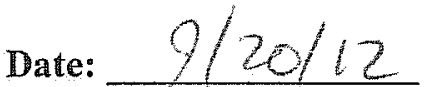

I. Joseph:

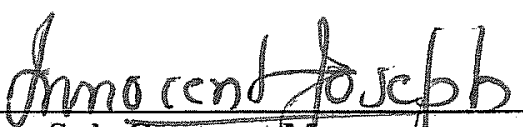

Energy Solutions Sub-Contract Manager

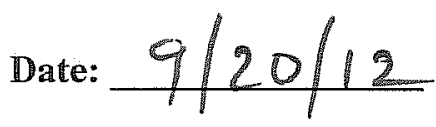




\section{TABLE OF CONTENTS}

SECTION 1.0 INTRODUCTION ……………

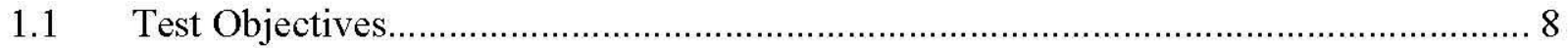

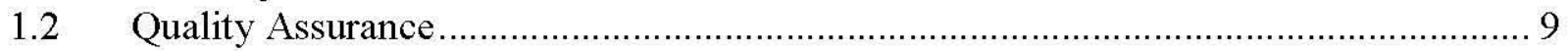

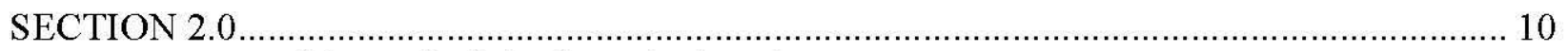

2.1 Compositions of High Bismuth Phosphate Wastes ...................................................... 10

SECTION 3.0

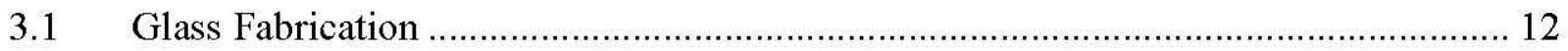

3.2 Glass Compositional Analysis ………………….............................................. 12

3.3 Crystallinity in Glass Samples after Isothermal Heat Treatment.................................. 12

3.4 Foaming of Glass Sample during Canister Centerline Cooling................................... 13

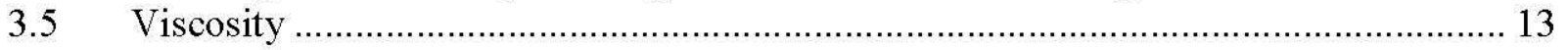

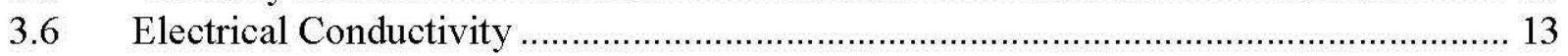

$3.7 \quad$ Product Consistency Test (PCT) …………………………………………..... 14

$3.8 \quad$ Toxicity Characteristic Leaching Procedure (TCLP) ………..................................... 14

SECTION 4.0 GLASS FORMULATION APPROACH ……………………………............... 15

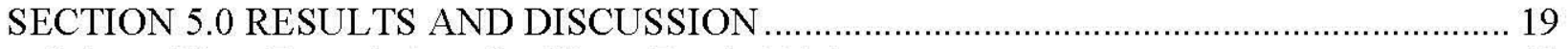

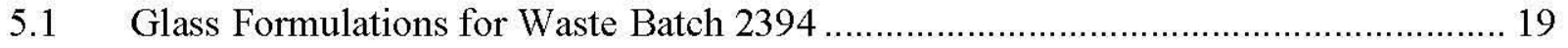

5.2 Glass Formulations for Waste Batch 4098 ………................................................ 20

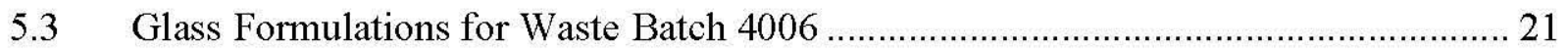

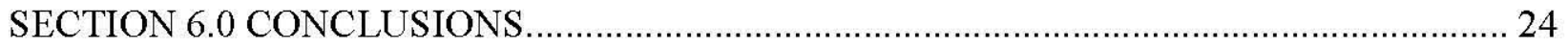

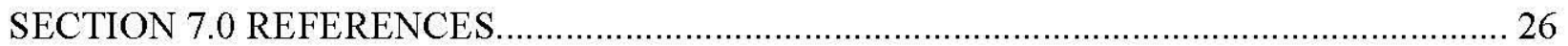




\section{List of Tables}

Table 1 Compositional Summary (wt\% Oxide Basis) of the Bi-Limited Waste and the Candidate Wastes Selected.

$\mathrm{T}-1$

$\begin{array}{lll}\text { Table } 2 & \text { Compositional Summary (wt\% Oxide Basis) of the HLW Simulants. } & \text { T-2 } \\ \text { Table } 3 & \text { HLW Canister Centerline Cooling Temperature Profile [13]. } & \text { T-3 }\end{array}$

Table 4 Target Compositions of HLW Glasses Previously Developed for Bi-Limited Waste [1,3].

$\mathrm{T}-4$

Table 5a Target and XRF Analysis of Glass Compositions for Waste Batch 2394 (wt\%). T $\quad$ T-5

Table 5b Target and XRF Analysis of Glass Compositions for Waste Batch 4098 (wt\%). $\quad$ T-7

Table 5c Target and XRF Analysis of Glass Compositions for Waste Batch 4006 (wt\%). $\quad$ T-11

Table 6a Characterization of Glass Samples for Waste Batch $2394 . \quad$ T-15

Table $6 \mathrm{~b} \quad$ Characterization of Glass Samples for Waste Batch $4098 . \quad$ T-16

Table 6c Characterization of Glass Samples for Waste Batch $4006 . \quad T-18$

Table $7 \quad$ Viscosity and Electrical Conductivity of Selected Bi-P Glass Melts. $\quad$ T-20

Table $8 \quad$ Normalized 7-Day PCT Element Releases for Selected Bi-P HLW Glasses. $\quad$ T-21

Table 9 TCLP Element Releases from Selected Bi-P HLW Glasses. 


\section{List of Figures}

Figure 1 Cross sections of glass CCC samples of Waste Batch $2394 . \quad$ F-1

Figure 2a SEM image of HLWBi2394-3 heat treated at $950^{\circ} \mathrm{C} . \quad \mathrm{F}-2$

Figure $2 \mathrm{~b} \quad$ SEM image of HLWBi2394-3 heat treated at $900^{\circ} \mathrm{C} . \quad \mathrm{F}-2$

Figure 2c SEM image of HLWBi2394-3 heat treated at $850^{\circ} \mathrm{C}$. $\quad$ F-3

Figure 2d SEM image of HLWBi2394-3 heat treated at $800^{\circ} \mathrm{C}$. $\quad \mathrm{F}-3$

Figure 3a SEM image of HLWBi2394-4 heat treated at $950^{\circ} \mathrm{C} . \quad \mathrm{F}-4$

Figure $3 \mathrm{~b} \quad$ SEM image of HLWBi2394-4 heat treated at $900^{\circ} \mathrm{C} . \quad \mathrm{F}-4$

Figure 3c SEM image of HLWBi2394-4 heat treated at $850^{\circ} \mathrm{C} . \quad \mathrm{F}-5$

Figure 3d SEM image of HLWBi2394-4 heat treated at $800^{\circ} \mathrm{C} . \quad \mathrm{F}-5$

Figure 4 Total amount of crystalline phases (vol\%) after isothermal heat treatment $\quad$ F-6

of HWBi2394-3 (45 wt\% waste loading, blue open circles) and HWBi2394-4

(40 $\mathrm{wt} \%$ waste loading, red open squares).

$\begin{array}{lll}\text { Figure } 5 & \text { Cross sections of glass CCC samples of Waste Batch } 4098 . & \text { F-7 }\end{array}$

Figure 6a SEM image of HLWBi4098-6 heat treated at $950^{\circ} \mathrm{C} . \quad \mathrm{F}-10$

Figure $6 \mathrm{~b} \quad$ SEM image of HLWBi4098-6 heat treated at $900^{\circ} \mathrm{C} . \quad \mathrm{F}-10$

Figure 6c SEM image of HLWBi4098-6 heat treated at $850^{\circ} \mathrm{C} . \quad \mathrm{F}-11$

Figure 6d SEM image of HLWBi4098-6 heat treated at $800^{\circ} \mathrm{C} . \quad$ F-11

Figure 7a SEM image of HLWBi4098-7 heat treated at $950^{\circ} \mathrm{C} . \quad$ F-12

Figure $7 \mathrm{~b} \quad$ SEM image of $\mathrm{HLWBi} 4098-7$ heat treated at $900^{\circ} \mathrm{C} . \quad \mathrm{F}-12$

Figure 7c SEM image of HLWBi4098-7 heat treated at $850^{\circ} \mathrm{C} . \quad \mathrm{F}-13$

Figure $7 \mathrm{~d} \quad$ SEM image of $\mathrm{HLWBi} 4098-7$ heat treated at $800^{\circ} \mathrm{C} . \quad \mathrm{F}-13$

Figure $8 \quad$ Total amount of crystalline phases (vol\%) after isothermal heat treatment of $\quad$ F-14

HWBi4098-7 (45 wt\% waste loading, blue open circles) and HWBi4098-6 (40 wt \% waste loading, red open squares).

Figure $9 \quad$ Cross sections of glass CCC samples of Waste Batch $4006 . \quad$ F-15

Figure 10a SEM image of HLWBi4006-6 heat treated at $950^{\circ} \mathrm{C}$. $\quad$ F-18

Figure 10b SEM image of HLWBi4006-6 heat treated at $900^{\circ} \mathrm{C}$. $\quad$ F-18

Figure 10c SEM image of HLWBi4006-6 heat treated at $850^{\circ} \mathrm{C}$. $\quad$ F-19

Figure 10a SEM image of HLWBi4006-6 heat treated at $800^{\circ} \mathrm{C} . \quad$ F-19

Figure 11 Total amount of crystalline phases (vol\%) after isothermal heat treatment of $\quad$ F-20

HWBi4006-4 (45 wt\% waste loading, blue open circles) and HWBi4006-6 (40 wt \% waste loading, red open squares).

Figure 12a SEM image of HLWBi4006-7 heat treated at $950^{\circ} \mathrm{C}$.

F-21

Figure $12 \mathrm{~b}$ SEM image of HLWBi4006-7 heat treated at $800^{\circ} \mathrm{C} . \quad \mathrm{F}-21$

Figure 13a SEM image of HLWBi4006-4 heat treated at $950^{\circ} \mathrm{C} . \quad \mathrm{F}-22$

Figure 13b SEM image of HLWBi4006-4 heat treated at $900^{\circ} \mathrm{C} . \quad \mathrm{F}-22$

Figure 13c SEM image of HLWBi4006-4 heat treated at $850^{\circ} \mathrm{C} . \quad \mathrm{F}-23$

Figure 13d SEM image of HLWBi4006-4 heat treated at $800^{\circ} \mathrm{C}$ F-23 


\section{List of Abbreviations}

ANL-LRM - Argonne National Laboratory-Low Activity Waste Reference Material

ASME - American Society of Mechanical Engineers

CCC - Canister Centerline Cooling

DCP-AES - Direct Current Plasma Atomic Emission Spectroscopy

DWPF-EA - Defense Waste Processing Facility-Environmental Assessment

HLW - High Level Waste

HTWOS - Hanford Tank Waste Operations Simulator

NIST - National Institute of Standard and Technology

ORP - Office of River Protection

PCT - Product Consistency Test

QARD - Quality Assurance Requirements and Description

RPP - River Protection Project

SEM/EDS - Scanning Electron Microscopy/Energy Dispersive X-ray Spectroscopy

TCLP - Toxicity Characteristic Leaching Procedure

VGF - Vertical Gradient Furnace

VSL - Vitreous State Laboratory

WTP - Hanford Tank Waste Treatment and Immobilization Plant

XRF - X-ray Fluorescence Spectroscopy 


\section{SECTION 1.0 INTRODUCTION}

The processing rate of High Level Waste (HLW) at the Hanford Tank Waste Treatment and Immobilization Plant (WTP) depends on the waste loading in the HLW glass and the glass production rate. Both the waste loading and production rate have been the focus of on-going work for the Office of River Protection (ORP) performed at the Vitreous State Laboratory (VSL). Glass formulation development work at VSL has demonstrated the feasibility of increases in waste-loading from about $25 \mathrm{wt} \%$ to $33-50 \mathrm{wt} \%$ (based on waste oxide loading) in the glass for various waste streams [1]. Glass formulations and glass-forming additive blends were also developed for selected waste streams to maximize processing rates while maintaining high waste loadings and acceptable glass properties [2].

The WTP's overall mission will require the immobilization of tank waste compositions that are dominated by mixtures that include aluminum, chromium, bismuth, iron, phosphorus, zirconium, and sulfur compounds as waste-limiting components. The development work for the WTP baseline has focused on early HLW feeds, all of which are limited by iron. However, in order to develop the basis for the balance of the WTP mission, ORP has specified representative waste streams that are limited by other key components, for testing that was conducted previously at VSL [1]. The loadings of these wastes in HLW glass were expected to be limited by bismuth, chromium, aluminum, and aluminum plus sodium. Glass formulations that meet all processing and product quality requirements for each of these waste streams were developed with waste loadings ranging from 33 to $50 \mathrm{wt} \%$, which far exceed the minimum, and approach or meet the maximum levels specified by ORP [1]. The testing also identified new risks associated with those waste types.

For the Bi-limited waste, an HLW glass formulation with $50 \mathrm{wt} \%$ waste loading was successfully developed and tested [1]. This glass contains $6.71 \mathrm{wt} \%$ of $\mathrm{Bi}_{2} \mathrm{O}_{3}$, which suggests that a $70 \%$ reduction in glass volume is achievable when compared to the WTP contract minimum of $2 \mathrm{wt} \% \mathrm{Bi}_{2} \mathrm{O}_{3}$ when the waste loading is limited solely by $\mathrm{Bi}_{2} \mathrm{O}_{3}$. The maximum waste loading for the bismuth-limited waste was primarily limited by the crystallization of spinel and phosphate. In addition, however, crucible melts of high-bismuth glasses were observed to foam upon heat treatment using the WTP HLW canister centerline cooling (CCC) curve [1]. Such an occurrence during cooling of actual HLW canisters would be highly undesirable and could therefore represent a significant risk associated with processing of high bismuth/phosphorus wastes.

Subsequent testing was conducted at the crucible scale and on the HLW pilot melter (DM1200) to determine the nature, cause and extent of glass foaming when processing a high bismuth waste stream. Test results confirmed that the foaming behavior observed in crucible scale tests also occurred at larger scale under conditions prototypical of those at WTP [3]. The test results also demonstrated a compositional dependence of foaming for high-bismuth glasses, 
identifying phosphorus and chromium as contributors to the observed foaming, while bismuth was found to play no significant role, even though it is a major glass component [3]. Based on the test results, several methods were identified as potentially effective to mitigate the foaming observed during CCC. All of the previous work was conducted with a single high Bi-P waste composition and therefore testing of other potential high Bi-P HLW feeds to the WTP is required to assess whether similar foaming behavior is observed for those waste streams and whether similar mitigation approaches are effective.

It is worth noting that the foaming behavior observed in the high Bi-P waste occurred during cooling of the melt, unlike the case of more traditional foaming behavior that is observed during glass melting for which a substantial amount of literature is available. It is common to observe the foam development during batch melting and glass fining processes. In nuclear waste glasses, foaming can occur as the result of reduction of multivalent oxides with increasing melt temperature $[4,5]$. As demonstrated in numerous studies, foaming can also occur during the batch reactions as raw materials are converted to glass melt [6] or during fining in the later stage of glass production, as for example in the case of decomposition of sulfate dissolved in glass melts [7]. However, as documented previously [3], for the WTP high Bi-P melts, foaming did not occur during feed to melt conversion or as a result of increasing melt temperature. The foaming phenomenon that is the subject of this work is observed during controlled cooling of the melt according to the temperature profile that simulates the WTP HLW centerline canister cooling curve $[1,3]$. Consequently, a different mechanism is apparently responsible for this type of foaming, as described previously [3].

This report presents results from tests with new glass formulations that have been developed for several high Bi-P HLW compositions that are expected to be processed at the WTP that have not been tested previously. WTP HLW feed compositions were reviewed to select waste batches that are high in Bi-P and that are reasonably distinct from the Bi-limited waste that has been tested previously $[1,3]$. Three such high Bi-P HLW compositions were selected for this work [8]. The focus of the present work was to determine whether the same type of issues as seen in previous work with high-Bi HLW $[1,3]$ will be seen in HLW with different concentrations of $\mathrm{Bi}, \mathrm{P}$ and $\mathrm{Cr}$ and also whether similar glass formulation development approaches would be successful in mitigating these issues. New glass compositions were developed for each of the three representative Bi-P HLW wastes and characterized with respect to key processing and product quality properties and, in particular, those relating to crystallization and foaming tendency.

\section{$1.1 \quad$ Test Objectives}

As described in the Test Plan for this work [8], the primary objectives of the work were to: select high Bi-P HLW compositions that are expected to be processed at the WTP that have not been tested previously; develop high waste loading glass formulations that meet the necessary processing and product quality requirements for each of the three selected high Bi-P WTP HLW streams; investigate the extent of foaming observed during CCC with these new waste compositions; and investigate glass formulation methods to mitigate such foaming. 


\subsection{Quality Assurance}

This work was performed according to the quality assurance program that is in place at VSL. That program is compliant with applicable criteria of 10 CFR 830.120; Office of Civilian Waste Management DOE/RW-0333P, Quality Assurance Requirements and Description (QARD) Revision 20; the American Society of Mechanical Engineers (ASME) NQA-1, 2004; and DOE Order 414.1 C, Quality Assurance. The requirements of DOE/RW-0333P were applicable to the following specific aspects of this work:

- Crucible melt preparation of HLW glasses;

- Analysis of HLW crucible melt glasses;

- PCT of HLW glasses.

The program is supplemented by a Quality Assurance Project Plan for ORP work [9] that is conducted at VSL. Test and procedure requirements by which the testing activities are planned and controlled are also defined in this plan. The program is supported by VSL standard operating procedures that were used for this work [10]. 


\section{SECTION 2.0 WASTE COMPOSITIONS}

Glass formulation work performed previously at VSL for high bismuth phosphate wastes focused on waste compositions provided by WTP [11] and ORP [1]. The WTP Project supplied waste feed compositions that were from dynamic flow-sheet modeling runs using the WTP Dynamic Model (Gensym G2) for initial waste delivery scenarios. These scenarios involved the blending of various waste types (e.g., bismuth phosphate waste) in selected WTP tanks (e.g., C-104). Some of these wastes contained moderately high concentrations of bismuth and phosphate. In contrast, the Bi-limited waste provided by ORP contained considerably higher concentrations of these components (i.e., $12.91 \mathrm{wt} \% \mathrm{Bi}_{2} \mathrm{O}_{3}$ and $9.60 \mathrm{wt} \% \mathrm{P}_{2} \mathrm{O}_{5}$ ). Glass formulations with high waste loadings have been successfully developed and tested for wastes from both sources $[1,11]$. The present work investigated other high Bi-P HLW compositions that are expected to be processed at the WTP that have not been tested previously.

The WTP HLW feed compositions from the WTP System Plan, Rev 6 [12] were used as the source of high Bi-P HLW compositions for this work. A review of the WTP HLW feed composition data [11] was conducted to select the waste compositions for glass formulation development. This section summarizes the results of the review and the high Bi-P waste compositions selected for glass formulation development.

\subsection{Compositions of High Bismuth Phosphate Wastes}

Within the River Protection Project (RPP), the Hanford Tank Waste Operations Simulator (HTWOS) is a dynamic computer model that tracks the waste through storage, retrieval, feed staging and treatment processes. The HTWOS output provides WTP feed vectors, which include information on feed compositions, quantities and dates. The HTWOS baseline case for the WTP System Plan, Rev 6 feed compositions was the basis for the selection of high Bi-P waste compositions to be tested in this work.

The HTWOS compositional data were converted from units of $\mathrm{kg}$ to $\mathrm{wt} \%$ oxides for the present evaluation. A review of the HTWOS data shows that the WTP will process 4106 batches of HLW glass for the overall mission [12], each with its own waste feed and glass composition. The $\mathrm{Bi}_{2} \mathrm{O}_{3}$ and $\mathrm{P}_{2} \mathrm{O}_{5}$ concentrations in the WTP HLW streams range from $0.04 \mathrm{wt} \%$ to $11.95 \mathrm{wt} \%$ and $0.59 \mathrm{wt} \%$ to $13.00 \mathrm{wt} \%$, respectively. These values can be compared with $12.91 \mathrm{wt} \% \mathrm{Bi}_{2} \mathrm{O}_{3}$ and $9.60 \mathrm{wt} \% \mathrm{P}_{2} \mathrm{O}_{5}$ found in the Bi-limited waste provided previously by ORP [1]. Many of the HTWOS batches with high $\mathrm{Bi}$ or $\mathrm{P}$ contents are also high in other components that are potentially waste-loading limiting; such streams were therefore not selected for the current work. For example, many waste batches with high $\mathrm{Bi}_{2} \mathrm{O}_{3}$ (or $\mathrm{P}_{2} \mathrm{O}_{5}$ ) concentrations also include $\mathrm{SO}_{3}$ in very high concentrations such that the $\mathrm{SO}_{3}$ will be the waste loading limiting component instead of $\mathrm{Bi}_{2} \mathrm{O}_{3}$ (or $\mathrm{P}_{2} \mathrm{O}_{5}$ ); one such case is waste batch number 4077, which 
contains $12.09 \mathrm{wt} \% \mathrm{P}_{2} \mathrm{O}_{5}$ and $3.56 \mathrm{wt} \% \mathrm{SO}_{3}$ but this waste was not chosen because the HLW glass formulation is expected to be limited by $\mathrm{SO}_{3}$.

Based on the above review, three waste compositions from the HTWOS output were selected for this work: Waste Batch Number 2394, 4006, and 4098. These composition are listed without the minor oxides (i.e., $<0.1 \mathrm{wt} \%$ ) in Table 1 , which also includes the Bi-limited waste composition previously studied for comparison. As seen in Table 1 , the compositions of the selected wastes show considerable differences from the original Bi-limited waste [1]. With the exception of $\mathrm{P}_{2} \mathrm{O}_{5}$ in Batch 4098, the concentrations of $\mathrm{Bi}_{2} \mathrm{O}_{3}$ and $\mathrm{P}_{2} \mathrm{O}_{5}$ in the selected wastes are generally lower than the respective values found in the Bi-limited waste. However, the ratio of $\mathrm{Bi}_{2} \mathrm{O}_{3}$ to $\mathrm{P}_{2} \mathrm{O}_{5}$ (Table 2) spans a wide range around that for the original Bi-limited waste. In addition, the waste loadings in HLW glasses for the selected wastes are still expected to be limited by $\mathrm{Bi}_{2} \mathrm{O}_{3}$ or $\mathrm{P}_{2} \mathrm{O}_{5}$. Furthermore, $\mathrm{Cr}_{2} \mathrm{O}_{3}$, which has been identified as the primary oxide that caused foaming in earlier tests [3], is present at similar or higher concentrations when compared to that found in the original Bi-limited waste. Finally, $\mathrm{MnO}$, which is present in all of these wastes (up to $6.82 \mathrm{wt} \%$ in Batch 4006), also may have important effects on foaming behavior in these glass melts. In contrast, $\mathrm{MnO}$ is absent from the original Bi-limited waste.

The waste compositions in Table 1 include the radioactive components $\mathrm{UO}_{3}$ and $\mathrm{ThO}_{2}$. These oxides are omitted from the HLW simulants for developing and testing glass formulations; the renormalized compositions after omission of $\mathrm{UO}_{3}$ and $\mathrm{ThO}_{2}$ are given in Table 2. Also given are the ratios of $\mathrm{Bi}_{2} \mathrm{O}_{3}$ and $\mathrm{P}_{2} \mathrm{O}_{5}$ to the respective WTP contract limit and the ratio of $\mathrm{Bi}_{2} \mathrm{O}_{3}$ to $\mathrm{P}_{2} \mathrm{O}_{5}$. 


\section{SECTION 3.0 \\ EXPERIMENTAL METHODS}

\subsection{Glass Fabrication}

Glass formulated for each of the high bismuth phosphate waste simulants was prepared from reagent grade or higher purity chemicals. The starting materials were batched and blended before loading into a platinum-gold crucible (1 liter). The typical batch size is $400 \mathrm{~g}$ of glass.

The loaded crucible was placed inside a Deltech furnace and melted at $1200^{\circ} \mathrm{C}$ for 2 hours. Mixing of the melt was enhanced mechanically using a platinum stirrer. The glass melt was quenched at the end of 120 minutes by pouring it onto a graphite plate. The glass was subsequently processed for various measurements.

\subsection{Glass Compositional Analysis}

The compositions of the prepared glasses were determined using X-ray fluorescence (XRF) spectroscopy. Selected glasses were analyzed for their boron and lithium contents with direct current plasma atomic emission spectroscopy (DCP-AES), as described below.

Powdered samples of the fabricated glasses ( -200 mesh) were analyzed with a PANalytical Axios mAX-Advanced XRF spectrometer. The spectrometer was calibrated over a range of glass compositions using standard reference materials traceable to National Institute of Standard and Technology (NIST), as well as waste glasses including the Argonne National Laboratory-Low Activity Waste Reference Material (ANL-LRM), the Defense Waste Processing Facility-Environmental Assessment (DWPF-EA) Glass, and Hanford WTP glasses. Analysis by $\mathrm{XRF}$ provides data for most glass components of interest except lithium and boron, which were represented by their target values or analyzed for selected glasses by DCP-AES.

Powdered glass samples for DCP-AES analysis were subjected to microwave-assisted total acid dissolution in Teflon vessels. Twenty milliliters $(\mathrm{ml})$ of a 1:5 mixture of concentrated $\mathrm{HF}: \mathrm{HNO}_{3}$ mixture was diluted to $50 \mathrm{ml}$ before use in dissolution. The resulting solutions were analyzed by DCP-AES.

\subsection{Crystallinity in Glass Samples after Isothermal Heat Treatment}

Glass samples ( $5 \mathrm{~g}$ each) were melted in platinum-gold crucibles with tight fitting covers at a temperature of $1200^{\circ} \mathrm{C}$ for 1 hour before a 70 hour isothermal heat treatment at a specific temperature between $800^{\circ} \mathrm{C}$ and $950^{\circ} \mathrm{C}$. At the end of the heat-treatment period, the glass samples were quenched by contacting the outside of the crucibles with water. This quenching froze in the 
phase assemblage present in the melt at the heat-treatment temperature. The heat-treated samples were prepared for Scanning Electron Microscopy/Energy Dispersive X-ray Spectroscopy (SEM/EDS) examination to determine the nature and the volume fraction of crystalline phases. In order to obtain a representative measure of the overall crystal fraction in the sample, the heat-treated glass was ground and sieved $(-18$ mesh or $\leq 1 \mathrm{~mm})$ before SEM/EDS analysis using a JEOL JSM-5910LV SEM with INCAEnergy 300 system.

\subsection{Foaming of Glass Sample during Canister Centerline Cooling}

The prepared HLW glasses underwent CCC heat treatment according to the CCC temperature profile provided by the WTP Project [13] (see Table 3). As is the case for isothermal heat-treatment, the glass samples ( 40 gram for each CCC experiment) in platinum alloy crucibles were maintained at a pre-melt temperature of $1200^{\circ} \mathrm{C}$ for 1 hour before initiation of CCC treatment. The samples recovered after $\mathrm{CCC}$ heat treatment were sectioned perpendicular to the surface, polished, and optically scanned. The digital images thus acquired were inspected on a computer monitor for signs of foam development.

\subsection{Viscosity}

The melt viscosity ( $\eta$ ) was measured using a Brookfield viscometer with a platinum/rhodium spindle and crucible. The relative torque of a rotating spindle immersed in molten glass was measured as a function of rotational velocity. Measurements were performed in the temperature $(T)$ range of $950-1250^{\circ} \mathrm{C}$. To facilitate comparison, the data were interpolated to standard temperatures (e.g., $1150^{\circ} \mathrm{C}$ ) using the Vogel-Fulcher equation:

$$
\ln \eta=A /\left(T-T_{\mathrm{o}}\right)+B
$$

where $A, B$, and $T_{\mathrm{o}}$ are fitting parameters. The equipment was calibrated at room temperature using standard oils of known viscosity and then checked at high temperatures using a National Institute of Standards and Technology (NIST) standard reference glass (SRM 711). Both precision and accuracy of the viscosity measurements are estimated to be within \pm 15 relative $\%$.

\subsection{Electrical Conductivity}

The electrical conductivity $(\sigma)$ of the glass melt was determined by measuring the resistance of the melt as a function of frequency using a calibrated platinum/rhodium electrode probe attached to an Agilent 4294A impedance analyzer. Measurements were performed over similar temperature ranges to those employed for the melt viscosity measurements. The results were analyzed using an equivalent circuit model to obtain the DC electrical conductivity. To facilitate comparison, the electrical conductivity data were then interpolated to standard temperatures (e.g., $1150^{\circ} \mathrm{C}$ ) using the Vogel-Fulcher equation: 


$$
\ln \sigma=A /\left(T-T_{\mathrm{o}}\right)+B
$$

where $A, B$, and $T_{\mathrm{o}}$ are fitting parameters. Estimated uncertainties in the electrical conductivity measurements are \pm 20 relative $\%$.

\subsection{Product Consistency Test (PCT)}

The product consistency test (PCT; ASTM C 1285) was used to evaluate the relative chemical durability of glasses by measuring the concentrations of the chemical species released from 100-200 mesh crushed glass (75-149 $\mu \mathrm{m})$ to the test solution (de-ionized water in this case). PCT tests on the HLW glasses were performed at $90^{\circ} \mathrm{C}$ for 7 days, in accordance with the current WTP contract requirement. The ratio of the glass surface area to the solution volume for this test is about $2000 \mathrm{~m}^{-1}$ (typically, $10 \mathrm{~g}$ of 100-200 mesh glass is immersed in $100 \mathrm{ml}$ of deionized water). All tests were conducted in triplicate, in 304L stainless steel vessels, and in parallel with a standard glass included in each test set. The internal standard was the DWPF-EA glass.

\subsection{Toxicity Characteristic Leaching Procedure (TCLP)}

The TCLP tests were performed at VSL using SW-846 Method 1311, which employs leaching of crushed glass $\left(<3 / 8^{\prime \prime}\right)$ in a sodium acetate buffer solution for 18 hours at $22^{\circ} \mathrm{C}$ with constant end-over-end agitation. 100 grams of glass was leached in 2 liters of TCLP extract, according to the extraction method for non-volatiles. The surface area to volume ratio for this test is about $20 \mathrm{~m}^{-1}$, which is about two orders of magnitude lower than that in the PCT. The leachates were analyzed by DCP-AES according to VSL standard operating procedures. 


\section{SECTION 4.0 GLASS FORMULATION APPROACH}

A series of glass formulations were developed and tested for each of the three high Bi-P HLW waste streams listed in Table 1 . The primary objective was to achieve high waste loadings for each of the HLW simulants while controlling crystallization and the melt foaming during cooling that has been observed in previous studies [1,3]. A total of 24 new glasses were designed, fabricated, and characterized in the present work and the results were analyzed to select recommended formulations for each of the three new HLW streams.

Results obtained from previous testing of WTP HLW high Bi-P glasses [1, 3] were used to guide the present formulation development work. Those studies showed that the waste loading was typically limited by melt foaming during $\mathrm{CCC}$ heat treatment and by crystallization of spinel/phosphate phases at $950^{\circ} \mathrm{C}[1,3]$. The glass formulation HLW-E-Bi6 with $50 \mathrm{wt} \%$ waste loading of the original bismuth-limited waste was developed in the first of those studies [1] (Table 4). However, it was noted that HLW-E-Bi6 displayed signs of unusual melt foaming during $\mathrm{CCC}$ heat treatment which was not well understood at the time [1]. That glass exhibited about $1.8 \mathrm{vol} \%$ of spinel and phosphate after heat treatment at $950^{\circ} \mathrm{C}$ and relatively slow melt rates in DM100 melter tests [1]. In a subsequent investigation [3], the foaming tendency of HLW-E-Bi6 during cooling was confirmed in one-third scale pilot melter tests on the DM1200 melter system [3].

Based on these observations, the origin of the foaming during melt cooling was investigated in a series of crucible melt tests [3]. The results of those tests showed that there was synergetic effect between $\mathrm{P}$ and $\mathrm{Cr}$ in gas generation which is believed to be due to the chemical affinity between $\mathrm{Cr}^{6+}$ and $\mathrm{P}^{5+}$. Phosphorus and chromium form poly ions containing both $\mathrm{P}$ and $\mathrm{Cr}$ that are closely related to the pyrophosphate and linear polyphosphate ions with $\mathrm{P}$ and $\mathrm{Cr}$ both in tetrahedral coordination. In this group of phosphochromates, one, two, three, or four of the $\mathrm{O}$ atoms of a $\mathrm{PO}_{4}$ group can be shared with tetrahedral $\mathrm{CrO}_{4}$ groups. Therefore, formation of the phosphochromate species in the P-rich HLW glass would probably stabilize $\mathrm{Cr}^{6+}$ and result in a higher $\mathrm{Cr}^{6+} / \mathrm{Cr}^{3+}$ ratio. In a simple homogeneous system, the redox equilibrium will normally shift towards the more reduced direction with increasing temperature. The available phase equilibrium data and experimental data suggest that two factors that involve heterogeneous reactions change this outcome [3]: 1) the solubilities of chromate within phosphate and phosphate within borosilicate; and 2) the competition for chromium between phosphochromate and spinel. Considering the strong affinity of trivalent chromium for the spinel lattice, it is not surprising that as the temperature is decreased, phosphochromate, after, and possibly even before, being separated from phosphate-rich domains would be reduced to $\mathrm{Cr}^{3+}$ in order to be accommodated by the more favorable spinel structure [3]. This mechanism can be summarized by the following reactions [3]: 


$$
\begin{aligned}
& \text { P-rich chromophosphoric species }(m) \rightarrow \mathrm{Na}_{4} \mathrm{P}_{2} \mathrm{O}_{7}(x l)+\mathrm{Na}_{3}\left[\mathrm{PCrO}_{7}\right](m) \\
& \mathrm{Na}_{3}\left[\mathrm{PCrO}_{7}\right](m)+1 / 2 \mathrm{NiO}(m) \rightarrow \mathrm{Na}_{3} \mathrm{PO}_{4}(x l)+1 / 2 \mathrm{NiCr}_{2} \mathrm{O}_{4}(S p)+3 / 4 \mathrm{O}_{2}(g)
\end{aligned}
$$

where $m$ indicates a melt phase, $x l$ a crystalline phase, $S p$ a spinel crystal, and $g$ a gas phase. A simple dimer type of phosphochromate is chosen to represent the proposed $\mathrm{Cr}$ and $\mathrm{P}$ poly ions in both reactions. Sodium pyrophosphate is chosen in the first reaction to match the same dimer configuration. In the second reaction, as $\mathrm{Cr}^{6+}$ is reduced to $\mathrm{Cr}^{3+}$, it is assumed that all sodium atoms associated with this phosphochromate remain with phosphate to form a less polymerized orthophosphate. $\mathrm{Cr}^{3+}$ will then react with appropriate available divalent cations (such as $\mathrm{Ni}^{2+}$ ) to form spinel crystals. Stoichiometrically, each mole of $\mathrm{Cr}_{2} \mathrm{O}_{3}$ generated will be accompanied by 1.5 moles of $\mathrm{O}_{2}$. A simple estimation shows that for a glass with a density of 2.6 $\mathrm{g} / \mathrm{cm}^{3}$ at $1100 \mathrm{~K}\left(833^{\circ} \mathrm{C}\right), 0.5 \mathrm{wt} \% \mathrm{Cr}_{2} \mathrm{O}_{3}$ in the glass will release an amount of gas equal to approximately 10 times the melt volume. Even under the assumption that only $10 \%$ of the $\mathrm{Cr}$ exists as phosphochromate at high temperature (before CCC cooling), the gas volume released will equal that of the glass melt [3].

The above discussion captures what appear to be the essential features of the foaming mechanism. However, a glass melt being subjected to $\mathrm{CCC}$ would evolve as an interrelated system. For example, the liquidus of the spinel phase will likely be influenced by the stability of $\mathrm{Cr}^{6+}$ in phosphochromate. As more $\mathrm{Cr}^{3+}$ becomes available, the spinel liquidus will move to a higher temperature in response. Nevertheless, the same general behavior would be expected.

Based on these results, several possible methods for mitigating the foaming observed on CCC were suggested [3]:

- Suppression of $\mathrm{Cr}^{6+}$ with a reductant or glass chemistry.

- $\quad$ Reduction of glass melt viscosity to facilitate release of gas bubbles.

- Formation of other competing phosphate species.

Suppression of $\mathrm{Cr}^{6+}$ will reduce the amount of oxygen gas that would be generated due to reduction of hexavalent chromium. In principle, this could be accomplished through the use of reductants or by decreasing the optical basicity of the host glass melt by, for example, decreasing the levels of alkalis such as sodium or potassium. However, this approach may cause unfavorable crystallization and high viscosities due to lack of flux.

A glass melt of considerably lower viscosity, especially at temperatures where the reduction reaction takes place, would possibly facilitate the escape of oxygen gas bubbles. However, considering the steep temperature dependence of melt viscosity and the adverse effects of very low melt viscosity on melter refractory corrosion, this route may have limited practical value.

The third option is aimed at creating direct competition with $\mathrm{Cr}^{6+}$ for the available phosphorus in the waste glass. The strategy is then to tie up the phosphorus that could otherwise 
interact with $\mathrm{Cr}^{6+}$ to form detrimental phosphochromate species. Chemical additives that can effectively bond to phosphorus, such as aluminum, may also act to suppress $\mathrm{Cr}^{6+}$ in glass. This approach for mitigation of foaming was emphasized and demonstrated to be quite effective in the previous work [3] and was also employed in the present study.

Based on the above mechanistic understanding of the observed foaming during melt cooling, several new formulations were developed to mitigate such foaming [3]. From that work, two new formulations were recommended, HLW-Bi-F3 and HLW-Bi-F9, which achieve the same waste loading as the earlier HLWE-Bi6 formulation but are free of melt foaming during CCC (Table 3). In addition, vertical gradient furnace (VGF) melt rate screening tests were performed in the development of these new formulations, the results of which indicated that both of the new formulations should show faster melting rates as compared to the original HLWE-Bi6 formulation [3]. HLW-Bi-F9 showed a faster melting rate than HLW-Bi-F3 but exhibited a higher crystal content after heat treatment at $950^{\circ} \mathrm{C}$ and some what poorer (though still acceptable) 7-day PCT releases. In view of the enormous economic benefits associated with the combination of high waste loading and fast melt rate, HLW-Bi-F9 [3] was used as a model formulation and starting point for the present glass formulation work recognizing, however, that the new waste compositions differ from that of the original bismuth-limited waste. More specifically, the new glass formulation development work was initially weighted toward the compositional space characterized by high boron, high alumina, high $\mathrm{Li} / \mathrm{Na}$ ratio, and low silica. Of the different glass former additives used in $\mathrm{HLW}$ glass formulation, $\mathrm{Al}_{2} \mathrm{O}_{3}, \mathrm{~B}_{2} \mathrm{O}_{3}, \mathrm{Li}_{2} \mathrm{O}$, and $\mathrm{SiO}_{2}$ were varied in this work. $\mathrm{CaO}$ was not increased because of the tendency for formation of $\mathrm{Ca}-\mathrm{P}$ phases in compositions with high concentrations of $\mathrm{Ca}$ and $\mathrm{P}$. The $\mathrm{Na}_{2} \mathrm{O}$ concentration was not increased because previous tests $[1,3]$ showed that $\mathrm{Na}_{2} \mathrm{O}$ was not particularly beneficial in reducing foaming.

Property-composition models were used to support the design of new glass formulations for testing, as is the standard practice at VSL for all glass formulation development work. The property-composition models that were used include melt viscosity, melt electrical conductivity and $\mathrm{T}_{1 \%}$. PCT and TCLP models were not used because these properties are usually not constraining for HLW glass formulation design. Since there is no model for foaming on CCC, glass formulation development to address this issue used an iterative approach with formulation design guided by past experience and results from the previous set of crucible melts. It should be noted, however, that since many of the new formulations being developed for ORP are compositionally outside the limits of applicability of the current models, the model predictions were part of several inputs into the selection of a glass formulation for testing; i.e., glass compositions were not necessarily rejected for testing solely because one of the models predicted a property value outside of the preferred limits. An iterative approach was used in the development of new glass formulations for the three high-Bi HLW streams because our past experience is that this approach would be more efficient and economical for the present objectives as compared to statistically designed composition matrices; the latter better suited to provide coverage of pre-defined composition spaces for subsequent model development.

After the crucible melt glasses were prepared as described in Section 3, the characterization was done in two steps. The earlier formulation efforts $[1,3]$ demonstrated that 
the waste loadings for high $\mathrm{Bi}-\mathrm{P}$ waste was typically limited by foaming during $\mathrm{CCC}$ and crystallization of spinel and other secondary phases at $950^{\circ} \mathrm{C}[1,3]$. Therefore, in the initial screening step, all glasses formulated in this work were characterized with respect to foaming and crystallization behavior before other properties were measured. If the prepared glass did not meet the processing requirements with regard to foaming and crystallization, measurements were generally not performed for the other properties. During glass formulation development work, equal emphasis was placed on crystallization and foaming because in most cases, once foaming was mitigated, crystallization became the waste loading limiting property. In the selection of candidate glass compositions for further testing, efforts were made to avoid any crystallization at the melt temperature while allowing small amounts of crystals ( 1 to $2 \mathrm{vol} \%$ ) at lower temperatures $\left(\sim 950{ }^{\circ} \mathrm{C}\right)$. Glasses that exhibited acceptable crystallization and $\mathrm{CCC}$ foaming behavior were identified and characterized in the second step with respect to other properties, including melt viscosity, electrical conductivity and product quality (Product Consistency Test and Toxicity Characteristic Leaching Procedure). The results were then reviewed to select recommended formulations for each of the three new high Bi-P waste streams. 


\section{SECTION 5.0 \\ RESULTS AND DISCUSSION}

\subsection{Glass Formulations for Waste Batch 2394}

Waste Batch 2394 has the highest concentrations of $\mathrm{Bi}_{2} \mathrm{O}_{3}$ and $\mathrm{Fe}_{2} \mathrm{O}_{3}$ and the lowest concentration of $\mathrm{P}_{2} \mathrm{O}_{5}$ among the three HLW streams investigated in this work (Table 2). Formulation HWBi2394-1 for Waste Batch 2394 (Table 5a) has $50 \mathrm{wt} \%$ waste loading and has $15.2 \mathrm{wt} \% \mathrm{~B}_{2} \mathrm{O}_{3}, 4 \mathrm{wt} \% \mathrm{Li}_{2} \mathrm{O}$ and $10.9 \mathrm{wt} \% \mathrm{Na}_{2} \mathrm{O}$. This formulation showed minor signs of melt foaming in the cross section of its $\mathrm{CCC}$ sample (Figure 1) and about $1.1 \mathrm{vol} \%$ spinel crystallization after heat treatment at $950^{\circ} \mathrm{C}$ (Table 6a). $\mathrm{HWBi} 2394-2$ at the same $50 \mathrm{wt} \%$ waste loading used more $\mathrm{B}_{2} \mathrm{O}_{3}$ and $\mathrm{Li}_{2} \mathrm{O}$ but no $\mathrm{Na}_{2} \mathrm{O}$ as glass forming additives and did not show any signs of melt foaming but contained nearly $2 \mathrm{vol} \%$ spinel crystals after $950^{\circ} \mathrm{C}$ heat treatment (Table 6a). For HWBi2394-3, which is similar to HWBi2394-2 but at a lower waste loading of $45 \mathrm{wt} \%$, crystallization of spinel decreased to about $0.8 \mathrm{vol} \%$. A further reduction in waste loading to $40 \mathrm{wt} \%$ in HWBi2394-4 resulted in a similar amount of crystallization. HWBi2394-3 and HWBi2394-4 showed no evidence of melt foaming during CCC (Figure 1). However, the relatively low $\mathrm{SiO}_{2}$ and high $\mathrm{B}_{2} \mathrm{O}_{3}$ content in HWBI2394-3 resulted in a rather fluid melt $(\sim 16$ poise at $1150^{\circ} \mathrm{C}$, Table 7). The addition of $5 \mathrm{wt} \% \mathrm{SiO}_{2}$ at the expense of $5 \mathrm{wt} \%$ waste loading brought the viscosity into the normal range for processing in HWBi2394-4 (25 poise at $1150^{\circ} \mathrm{C}$ ) (Table 7).

Crystalline phases in heat treated samples of the glasses were identified by SEM/EDS, and volume percents of crystals were determined by SEM in conjunction with image analysis. SEM images of heat treated samples of HLWBi2394-3 are given in Figures 2a-d. SEM images of the samples heat treated at $950^{\circ} \mathrm{C}$ and $900^{\circ} \mathrm{C}$ (Figures $2 \mathrm{a}$ and $2 \mathrm{~b}$ ) both show Fe-Cr-Ni spinels with Mn. HLWBi2394-3 samples heat treated at $850^{\circ} \mathrm{C}$ and $800^{\circ} \mathrm{C}$ (Figures $2 \mathrm{c}$ and $2 \mathrm{~d}$ ) show apatite in addition to the spinel crystals seen at the higher heat treatment temperatures. SEM images of heat treated samples of HLWBi2394-4 are given in Figures 3a-d. SEM images of the samples heat treated at $950^{\circ} \mathrm{C}$ and $900^{\circ} \mathrm{C}$ (Figures $3 \mathrm{a}$ and $3 \mathrm{~b}$ ) show only Fe-Cr-Ni spinels with $\mathrm{Mn}$. Sample heat treated at $850^{\circ} \mathrm{C}$ (Figure 2c) show apatite in addition to the spinel crystals seen at the higher heat treatment temperatures. An HLWBi2394-4 sample heat treated at $800^{\circ} \mathrm{C}$ (Figure 2d) shows spinel, apatite and an Fe-Cr oxide phase. As shown in Figure 4, the total crystal contents are similar for HWBi2394-3 and HWBi2394-4 after heat treatment at temperatures from 950 to $800^{\circ} \mathrm{C}$ but considerably more phosphate phase formed at $800^{\circ} \mathrm{C}$ in HWBi2394-4 in spite of its lower waste loading.

HWBi2394-3 and HWBi2394-4 both show acceptable leaching results on the 7-day PCT and the TCLP. The normalized PCT releases (Table 8) are about an order of magnitude smaller than those for the DWPF-EA reference glass and the TCLP releases are well below the delisting limits (Table 9). 
Overall, both HWBi2394-3 and HWBi2394-4 are recommended for further considerations for Waste Batch 2394 based on their processing and performance parameters. The viscosity of HWBi2394-3 is somewhat below the lower limit for WTP HLW glasses but has higher waste loading of $45 \mathrm{wt} \%$ and slightly lower total crystal content. HWBi2394-4 has a viscosity that is within the WTP HLW limits but has a $5 \mathrm{wt} \%$ lower waste loading.

\subsection{Glass Formulations for Waste Batch 4098}

Waste Batch 4098 has the highest concentrations of $\mathrm{P}_{2} \mathrm{O}_{5}$ and $\mathrm{Al}_{2} \mathrm{O}_{3}$ and the lowest concentration of $\mathrm{Bi}_{2} \mathrm{O}_{3}$ among the three HLW waste streams investigated in this work (Table 2). Formulation HWBi4098-1 for Waste Batch 4098 has $50 \mathrm{wt} \%$ loading and includes high boron and aluminum and added lithium (Table $5 \mathrm{~b}$ ). Although crystallization is limited with a minor presence of spinel and phosphate after isothermal heat treatment (Table 6b), gas vesicles are present in the CCC sample indicative of melt foaming during the cooling process (Figure 2). Two formulations at $45 \mathrm{wt} \%$ waste loading with 4 to $6 \mathrm{wt} \% \mathrm{CaO}$ (HWBi4098-2 and HWBi40983) successfully suppressed foaming during CCC but produced substantially more crystallization of calcium phosphate (Table 6b, Figure 5). HWBi4098-4 was formulated with similar glass forming additives but at $5 \mathrm{wt} \%$ lower waste loading than HWBi4098-1. Crystallization in HWBi4098-4 after isothermal heat treatment was similar to that of HWBi4098-1 (Table 6b) and only one gas vesicle was observed near the bottom of the crucible in the CCC sample (Figure 5). However, the as-melted glass specimens of both HWBi4098-4 and HWBi4098-1 displayed traces of crystallization by visual inspection. HWBi4098-5 is a variation from HWBi4098-4 with the same $45 \mathrm{wt} \%$ waste loading but with $5 \mathrm{wt} \% \mathrm{SiO}_{2}$ in exchange for $\mathrm{Al}_{2} \mathrm{O}_{3}$, which resulted in slightly more crystallization (Table 6b). HWBi4098-7 includes further additions of $\mathrm{Al}_{2} \mathrm{O}_{3}, \mathrm{~B}_{2} \mathrm{O}_{3}$ and $\mathrm{Li}_{2} \mathrm{O}$ at constant $45 \mathrm{wt} \%$ waste loading to HWBi4098-4 and displayed very limited crystallization and no sign of foaming after $\mathrm{CCC}$ heat treatment.

Four glasses were formulated at waste loadings below $45 \mathrm{wt} \%$ for Waste batch 4098 . HWBi4098-6, which is a lower waste loading version of $\mathrm{HWBi} 4098-4$ with more $\mathrm{SiO}_{2}$ as a glass forming additive, showed similar crystal content to HWBi4098-7 and more phosphate formation at 900 and $850^{\circ} \mathrm{C}$. One gas vesicle was evident near the bottom of the CCC sample (Figure 5). There were some signs of trace crystallization in the as-melted glasses of HWBi4098-9 and HWBi4098-8 with 40 wt\% loading. HWBi4098-10 at 35 wt\% waste loading shows little crystallization and is free of foaming during $\mathrm{CCC}$ heat treatment but at the expense of significantly lower waste loading.

SEM images of heat treated samples of HLWBi4098-6 are given in Figures 6a-d. SEM images of the sample heat treated at $950^{\circ} \mathrm{C}$ (Figure 6a) show only $\mathrm{Fe}-\mathrm{Cr}-\mathrm{Ni}-\mathrm{Mn}$ spinels. The sample heat treated at $900^{\circ} \mathrm{C}$ (Figure 6b) shows apatite and La-phosphate in addition to the same type of spinel observed at $950^{\circ} \mathrm{C}$. An HLWBi4098-6 sample heat treated at $850^{\circ} \mathrm{C}$ (Figures 6c) shows apatite in addition to the spinel crystals seen at the higher heat treatment temperatures. The sample heat treated at $800^{\circ} \mathrm{C}$ (Figure 6d) shows spinel, apatite and La-phosphate. The SEM image also shows some dark cavities that are probably voids formed by the dissolution of alkaline phosphates during sample polishing. SEM images of heat treated samples of 
HLWBi4098-7 are given in Figures 7a-d. SEM images of the samples heat treated at $950^{\circ} \mathrm{C}$ and $900^{\circ} \mathrm{C}$ (Figures $7 \mathrm{a}$ and $3 \mathrm{~b}$ ) show only $\mathrm{Fe}-\mathrm{Cr}-\mathrm{Ni}-\mathrm{Mn}$ spinels. The sample heat treated at $850^{\circ} \mathrm{C}$ (Figure 7c) shows apatite in addition to the Fe-Cr-Ni-Mn spinel crystals. AN HLWBi4098-7 sample heat treated at $800^{\circ} \mathrm{C}$ shows spinel (Figure $7 \mathrm{~d}$ ), apatite (Figure 7e) and dark cavities likely due to dissolution of alkaline phosphates during sample polishing (Figure $7 \mathrm{~d}$ ). The volume percent crystals are comparable for HLWBi4098-6 and HLWBi4098-7, as shown in Figure 8.

In summary, HWBi4098-7 (45 wt\% waste loading) and HWBi4098-6 (40 wt\% waste loading) represent the best compromises in terms of high waste loading, acceptable crystal contents, and absence or near-absence of foaming during $\mathrm{CCC}$ heat treatment. The normalized $7-$ day PCT releases of $\mathrm{B}$ and $\mathrm{Na}$ for HWBi4098-7 are nearly three times those of HWBi4098-6 (Table 8). Nevertheless, the normalized 7-day PCT releases for both glasses are almost an order of magnitude lower than those of the DWPF-EA reference glass. The TCLP releases for both glasses are well below the delisting limits (Table 9).

Overall, both HWBi4098-7 and HWBi4098-6 are acceptable formulations for Waste Batch 4098 with regard to their leaching resistance, crystal content, and foaming during CCC heat treatment. The viscosity and electrical conductivity of HWBi4098-7 are within the WTP HLW operational ranges (Table 7); although the viscosity and electrical conductivity for HWBi4098-6 were not measured, they are expected to also be within the WTP limits based on the results for HW4098-7 and the compositions of the two glasses.

\subsection{Glass Formulations for Waste Batch 4006}

Waste Batch 4006 with the highest concentrations of $\mathrm{Na}_{2} \mathrm{O}, \mathrm{Cr}_{2} \mathrm{O}_{3}, \mathrm{MnO}$, and $\mathrm{NiO}$ among the three HLW streams investigated in this work (Table 2) proved to be the most challenging waste stream to incorporate at high waste loadings due to spinel crystallization.

Formulation for Waste Batch 4006 started at $50 \mathrm{wt} \%$ loading with relatively high boron and aluminum oxides $(\sim 15 \mathrm{wt} \%$ each). Lithium oxide was not used in HWBi4006-1 (Table 5c) due to the high sodium content in Waste Batch 4006. Although melt foaming in the CCC sample was negligible (Figure 9), nearly 3 vol\% of crystalline phases (spinel plus phosphate) was present in the glass after $950^{\circ} \mathrm{C}$ heat treatment (Table $6 \mathrm{c}$ ). An additional $5 \mathrm{wt} \%$ of $\mathrm{B}_{2} \mathrm{O}_{3}$ and $\mathrm{SiO}_{2}$ at the expense of $5 \mathrm{wt} \%$ waste loading in $\mathrm{HWBi} 4006-3$ did not reduce the amount of crystallization. In $\mathrm{HWBi} 4006-2,2 \mathrm{wt} \% \mathrm{Li}_{2} \mathrm{O}$ was added in exchange for $\mathrm{B}_{2} \mathrm{O}_{3}$ and $\mathrm{SiO}_{2}$ in HWBi4006-3 at the same $45 \mathrm{wt} \%$ waste loading, which reduced spinel crystallization to 1.1 vol\%; however, the as-melted glass sample of HWBi4006-2 showed trace crystallization by visual inspection.

HWBi4006-6, which has a lower waste loading of $40 \mathrm{wt} \%$ but is otherwise similar to HWBi4006-2, showed similar crystal content $\left(1.1 \mathrm{vol} \%\right.$ at $950^{\circ} \mathrm{C}$ ) (Table $6 \mathrm{c}$ ) and good phase quality based on visual inspection of the as-melted glass. SEM images of heat treated samples of HLWBi4006-6 are given in Figures 10a-d. SEM images of the sample heat treated at $950^{\circ} \mathrm{C}$ (Figure 10a) show only Fe-Cr-Ni-Mn spinels. The samples heat treated at $900^{\circ} \mathrm{C}$ and $850^{\circ} \mathrm{C}$ 
The Catholic University of America Vitreous State Laboratory
Development of High Waste Loading HLW Glasses for High Bismuth Phosphate Wastes Final Report, VSL-12R2550-1, Rev. 0

(Figures 10b and 10c) show La-phosphate in addition to Fe-Cr-Ni-Mn spinel. An HLWBi4006-6 sample heat treated at $800^{\circ} \mathrm{C}$ (Figure 10d) shows La-phosphate and a Ni-rich spinel with smaller amounts of $\mathrm{Cr}, \mathrm{Fe}$ and $\mathrm{Mn}$. Na-Ca phosphate phases were also seen in samples heat treated at $800^{\circ} \mathrm{C}$ and $850^{\circ} \mathrm{C}$. The volume percent crystals in heat treated samples of HLWBi4006-6 varies from about $1.1 \mathrm{vol} \%$ at $950^{\circ} \mathrm{C}$ to $3.5 \mathrm{vol} \%$ at $800^{\circ} \mathrm{C}$, as shown in Table $6 \mathrm{c}$ and Figure 11.

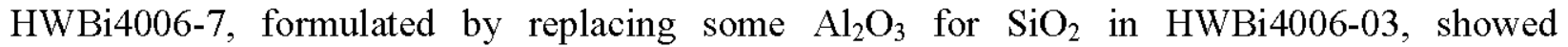
somewhat less crystallization of a $\mathrm{Na}-\mathrm{Ca}$ phosphate phase but more spinel crystallization after isothermal heat treatment. SEM/EDS analysis indicated that the spinel crystals present in the heat treated HWBi4007-7 accommodated considerable amounts of $\mathrm{Al}_{2} \mathrm{O}_{3}$, which is apparently responsible for the increased spinel formation in HWBi4006-7. SEM images of HLWBi4006-7 samples heat treated at $950^{\circ} \mathrm{C}$ and $800^{\circ} \mathrm{C}$ are given in Figures $12 \mathrm{a}$ and $12 \mathrm{~b}$, respectively. The sample heat treated at $950^{\circ} \mathrm{C}$ (Figure 12a) shows La-phosphate and an Fe-Cr-Ni-Mn spinel with Al. SEM images of the sample heat treated at $800^{\circ} \mathrm{C}$ (Figure 12b) show La-phosphate, $\mathrm{Fe}-\mathrm{Cr}-\mathrm{Ni}-\mathrm{Mn}$ spinel with considerable amount of $\mathrm{Al}$, and dark cavities likely due to the dissolution of Na-Ca phosphates during sample polishing.

Based on these results, the $\mathrm{Al}_{2} \mathrm{O}_{3}$ from the glass forming additives was decreased for formulations HWBi4006-4 and HWBi4006-5, both of which have 45 wt $\%$ waste loading. HWBi4006-4 and HWBi4006-5, which differ in their $\mathrm{B}_{2} \mathrm{O}_{3}$ and $\mathrm{SiO}_{2}$ contents $(15 \mathrm{wt} \%$ and $42 \mathrm{wt} \%, 10 \mathrm{wt} \%$ and $47 \mathrm{wt} \%$, respectively), do not show signs of foaming during $\mathrm{CCC}$ and show considerably less spinel crystallization and acceptable total crystal contents after heat treatment. SEM images of heat treated samples of HLWBi4006-4 are given in Figures 13a-d. All of the samples show spinels with varying amounts of $\mathrm{Ni}, \mathrm{Cr}, \mathrm{Mn}$ and $\mathrm{Fe}$, and $\mathrm{Na}-\mathrm{Ca}$ phosphate partially dissolved during sample polishing. The volume percent crystals in heat treated samples of HLWBi4006-4 varies from about $1.1 \mathrm{vol} \%$ at $950^{\circ} \mathrm{C}$ to $3.2 \mathrm{vol} \%$ at $800^{\circ} \mathrm{C}$, as shown in Table $6 \mathrm{c}$ and Figure 11.

The formation of Al-bearing spinels also occurred in other high- and moderately high-Al glasses over a range of heat treatment temperatures: HWBi4006-8 with $40 \mathrm{wt} \%$ waste loading from 950 to $800^{\circ} \mathrm{C}$; HWBi4006-9 with $35 \mathrm{wt} \%$ loading from 950 to $800^{\circ} \mathrm{C}$ and $\mathrm{HWBi} 4006-10$ with $35 \mathrm{wt} \%$ waste loading at $800^{\circ} \mathrm{C}$. The total crystal content in HWBi4006-8 is high but the two other glasses are acceptable except for their relatively low waste loadings.

Three glasses for Waste Batch 4006 stand out: at $45 \mathrm{wt} \%$ waste loading, two low-Al formulations, HWBi4006-4 and HWBi4006-5, showed low crystal contents after heat treatment and no sign of foaming during CCC; at $40 \mathrm{wt} \%$ waste loading, HWBi4006-6 with moderately high $\mathrm{Al}$ and low $\mathrm{Si}$ shows similar characteristics.

The 7-day normalized PCT releases for HWBi4006-5 are lower than those for HWBi4006-4 and HWBi4006-6 by about an order of magnitude but the values for all three glasses are well below those for the DWPF-EA reference glass (Table 8). The better leaching resistance of $\mathrm{HWBi} 4006-5$ is likely due to its higher $\mathrm{SiO}_{2}$ content, which also resulted in a higher melt viscosity in comparison to HWBi4006-4. At the normal operating temperature $\left(1150^{\circ} \mathrm{C}\right)$, the viscosity of HWBi4006-5 (156 poise) is above the WTP upper limit whereas the viscosity of HWBi4006-4 (62 poise) falls within the WTP processing limits. The TCLP leachate 
concentrations for all of the glass are well below the delisting limits and therefore this is not a distinguishing factor.

Overall, therefore, HWBi4006-4 with $45 \mathrm{wt} \%$ waste loading is considered the best candidate for Waste Batch 4006. At $40 \mathrm{wt} \%$ waste loading, HWBi4006-6, which has a higher Al content and lower $\mathrm{Si}$ content is a viable alternative in view of its likely faster melt rate as suggested by the results from small scale VGF tests for HLW-Bi-F9, which has a similar composition [3]. 


\section{SECTION 6.0 CONCLUSIONS}

In this work new glass formulations have been developed for several high Bi-P HLW compositions that are expected to be processed at the WTP, but have not been tested previously. WTP HLW feed compositions were reviewed to select waste batches that are high in Bi-P and that are reasonably distinct from the Bi-limited waste that has been tested previously [1, 3]. Three such high Bi-P HLW compositions were selected for this work. New high waste loading glass formulations were developed for each of the three representative Bi-P HLW wastes and characterized with respect to key processing and product quality properties and, in particular, those relating to crystallization and foaming tendency during $\mathrm{CCC}$ heat treatment. Based on the results from previous investigations of the mechanism of the observed foaming during CCC heat treatment, formulation modifications were made as necessary to mitigate such foaming. A total of 24 new glasses were designed, fabricated, and characterized in this work and the results were analyzed to select candidate formulations for each of the three new HLW streams. The results for each of the three HLW streams are summarized below.

Of the three new HLW streams, Waste Batch 2394 has the highest $\mathrm{Fe}_{2} \mathrm{O}_{3}$ content and the lowest $\mathrm{P}_{2} \mathrm{O}_{5}$ content. Glass formulation issues observed for this stream included a strong tendency for spinel formation in addition to melt foaming during $\mathrm{CCC}$ heat treatment. Since $\mathrm{Al}_{2} \mathrm{O}_{3}$ was originally proposed as an additive to compete with chromium for phosphorus [3], less alumina was used for Waste Batch 2394, which is relatively poor in $\mathrm{P}_{2} \mathrm{O}_{5}$. HWBi2394-3, which has a moderate $\mathrm{Al}_{2} \mathrm{O}_{3}$ content, a high $\mathrm{B}_{2} \mathrm{O}_{3}$ content, and a waste loading of $45 \mathrm{wt} \%$, exhibited acceptable properties except for a relatively low melt viscosity. HWBi2394-4, which has a slightly lower waste loading of $40 \mathrm{wt} \%$, is an acceptable alternative formulation with improved melt viscosity that falls within the WTP operating range.

Waste Batch 4098 has the highest $\mathrm{P}_{2} \mathrm{O}_{5}$ content of the high Bi-P wastes studied to date. High-Al and high-B formulations were designed for this waste stream to manage the tendency for foaming during $\mathrm{CCC}$ heat treatment and crystallization. The crucible test results indicate that both HWBi4098-7 and HWBi4098-6 are acceptable formulations for Waste Batch 4098 with regard to their leaching resistance, crystal content and foaming during $\mathrm{CCC}$ heat treatment. HWBi4098-7 and HWBi4098-6 have waste loadings of 45 and $40 \mathrm{wt} \%$, respectively. The viscosity and electrical conductivity of HWBi4098-7 are within the WTP HLW operational ranges; although the viscosity and electrical conductivity for HWBi4098-6 were not measured, they are expected to also be within the WTP limits based on the results for HW4098-7 and the compositions of the two glasses.

Waste Batch 4006 contains significant amounts of spinel-forming components $(\mathrm{Cr}, \mathrm{Mn}$ and $\mathrm{Ni}$ ) as well as more than double the $\mathrm{Na}_{2} \mathrm{O}$ content of the original Bi-limited waste. Although previous studies [3] and the present work have shown that higher levels of aluminum are beneficial for controlling foaming during $\mathrm{CCC}$ heat treatment by virtue of competing with 
phosphorus for chromium, it was found that aluminum was incorporated to a significant extent into the spinels that formed in glasses for this waste stream, which resulted in undesirably high crystal contents at $950^{\circ} \mathrm{C}$. Therefore, the recommended formulation for this waste stream, HWBi4006-4 with a waste loading of $45 \mathrm{wt} \%$, contains much lower $\mathrm{Al}_{2} \mathrm{O}_{3}$ than the formulations for the other two waste streams. In addition, $\mathrm{Li}_{2} \mathrm{O}$ was not added to this formulation because of the high sodium content of Waste Batch 4006. This glass exhibits acceptable processing and product quality properties and although its 7-day PCT releases are relatively high, they are still well below those for the DWPF-EA reference glass.

In summary, the results from this work indicate that the foaming during $\mathrm{CCC}$ heat treatment that was observed for the original bismuth-limited waste stream $[1,3]$ is also observed to a greater or lesser extent in the three new high Bi-P waste streams that were studied. The mitigation approach through glass formulation that was developed previously [3] was found to be effective in controlling such foaming for the new waste streams. As with the original waste stream, control of spinel formation on heat treatment was also a significant factor in achieving high waste loadings for these waste streams.

The focus of the present work was to determine whether the same type of issues as seen in previous work with high-Bi HLW $[1,3]$, such as foaming during $\mathrm{CCC}$ heat treatment, would be seen in HLW streams with different concentrations of $\mathrm{Bi}, \mathrm{P}$ and $\mathrm{Cr}$ and also whether similar glass formulation development approaches would be successful in mitigating these issues. The work was not intended to provide final optimized formulations for subsequent melter testing. Thus, the candidate glass compositions from the current tests were characterized to ensure compliance with processing and product quality requirements applicable to the WTP. However, they were not subjected to vertical gradient furnace (VGF) tests to assess processing rates. We would recommend that such VGF tests be performed, followed by any indicated formulation adjustments, before any of the candidate compositions are selected for melter tests to support high-Bi HLW processing at the WTP. 


\section{SECTION 7.0 \\ REFERENCES}

[1] "High Level Waste Vitrification System Improvements," K.S. Matlack, H. Gan, W. Gong, I.L. Pegg, C.C. Chapman, and I. Joseph, Final Report, VSL-07R1010-1, Rev. 0, Vitreous State Laboratory, The Catholic University of America, Washington, DC, $04 / 16 / 07$.

[2] "Melt Rate Enhancement for High Aluminum HLW Glass Formulations," K.S. Matlack, H. Gan, M. Chaudhuri, W.K. Kot, W. Gong, T. Bardakci, I.L. Pegg, and I. Joseph, Final Report, VSL-08R1360-1, Rev. 0, Vitreous State Laboratory, The Catholic University of America, Washington, DC, 12/19/08.

[3] "Tests with High-Bismuth HLW Glasses," K.S. Matlack, H. Gan, W.K. Kot, M. Chaudhuri, R.K. Mohr, D.A. McKeown, T. Bardakci, W. Gong, A.C. Buechele, I.L. Pegg, and I. Joseph, Final Report, VSL-10R1780-1, Rev. 0, Vitreous State Laboratory, The Catholic University of America, Washington, DC, 12/13/10.

[4] "Melt Foaming, Foam Stability and Redox in Nuclear Waste Vitrification," D.S. Goldman, Journal of Non-Crystalline Solids, 84, 292-298 (1986).

[5] "Oxygen Evolution during $\mathrm{MnO}-\mathrm{Mn}_{3} \mathrm{O}_{4}$ Dissolution in a Borosilicate Melt," C. Lucktong and P. Hrma, Journal of the American Ceramic Society, 71 [5], 323-328 (1988).

[6] "Effect of Glass-Batch Makeup on the Melting Process," P. Hrma, M.J. Schweiger, C.J. Humerickhouse, J.A. Moody, R.M. Tate, T.T. Rainsdon, N.E. Tegrotenhuis, B.M. Arrigoni, J. Marcial, C.P. Rodriguez, B.H. Tincher, Ceramics-Silikáty, 54 [3], 193-211 (2010).

[7] "Foaming in Glass Melts Produced by Sodium Sulfate Decomposition under Ramp Heating Conditions," D-S Kim and P. Hrma, Journal of the American Ceramic Society, 75 [11] 2959-2963 (1992).

[8] "Improving Processing Characteristics of High Waste-Loading HLW Glasses for High Bismuth Phosphate Wastes," W.K. Kot, H. Gan, and I.L. Pegg, Test Plan, VSL-12T25501, Rev. 0, Vitreous State Laboratory, The Catholic University of America, Washington, DC, $02 / 27 / 12$.

[9] "Quality Assurance Project Plan for ORP/RPP-WTP Support Activities Conducted by VSL," QAPP-ORP, Rev. 2, Vitreous State Laboratory, The Catholic University of America, Washington, DC, 02/02/10. 
[10] "Master List of Controlled VSL Manuals and Standard Operating Procedures in Use," QA-MLCP, Rev. 78, Vitreous State Laboratory, The Catholic University of America, Washington, DC, $7 / 10 / 12$.

[11] "Baseline HLW Glass Formulations for Bismuth Phosphate Wastes," W.K. Kot, L. Myers, and I.L. Pegg, Final Report, VSL-07R1240-2, Rev. 0, Vitreous State Laboratory, The Catholic University of America, Washington, DC, 09/20/07.

[12] "River Protection Project System Plan," ORP-11242, Revision 6, U.S. Department of Energy, Office of River Protection, Richland, WA, October 2011.

[13] "Canister Centerline Cooling Data, Revision 1," L. Petkus, RPP-WTP Memorandum to C. Musick, CCN 074851, October 29, 2003. 
Table 1. Compositional Summary (wt\% Oxide Basis) of the Bi-Limited Waste and the Candidate Wastes Selected.

\begin{tabular}{|c|c|c|c|c|}
\hline Oxide & $\begin{array}{c}\text { Bi-Limited } \\
\text { Waste [1] }\end{array}$ & $\begin{array}{c}\text { WTP HLW } \\
\text { Glass Batch } \\
\text { 2394 Waste } \text { W }^{(1)}\end{array}$ & $\begin{array}{c}\text { WTP HLW } \\
\text { Glass Batch } \\
4006 \text { Waste }{ }^{(1)}\end{array}$ & $\begin{array}{c}\text { WTP HLW } \\
\text { Glass Batch } \\
4098 \text { Waste }^{(1)}\end{array}$ \\
\hline $\mathrm{Al}_{2} \mathrm{O}_{3}$ & $22.45 \%$ & $23.51 \%$ & $14.45 \%$ & $26.05 \%$ \\
\hline $\mathrm{B}_{2} \mathrm{O}_{3}$ & $0.58 \%$ & $0.30 \%$ & $0.50 \%$ & - \\
\hline $\mathrm{BaO}$ & $0.02 \%$ & $0.12 \%$ & - & - \\
\hline $\mathrm{Bi}_{2} \mathrm{O}_{3}$ & $12.91 \%$ & $11.52 \%$ & $6.15 \%$ & $2.31 \%$ \\
\hline $\mathrm{CaO}$ & $1.61 \%$ & $4.21 \%$ & $1.71 \%$ & $2.60 \%$ \\
\hline $\mathrm{Cr}_{2} \mathrm{O}_{3}$ & $1.00 \%$ & $1.09 \%$ & $1.46 \%$ & $0.97 \%$ \\
\hline $\mathrm{F}$ & $1.58 \%$ & $0.95 \%$ & $0.81 \%$ & $0.57 \%$ \\
\hline $\mathrm{Fe}_{2} \mathrm{O}_{3}$ & $13.40 \%$ & $20.93 \%$ & $6.27 \%$ & $7.51 \%$ \\
\hline $\mathrm{K}_{2} \mathrm{O}$ & $0.89 \%$ & $0.15 \%$ & $5.22 \%$ & $0.58 \%$ \\
\hline $\mathrm{La}_{2} \mathrm{O}_{3}$ & - $^{(2)}$ & - & $1.75 \%$ & $0.55 \%$ \\
\hline $\mathrm{Li}_{2} \mathrm{O}$ & $0.31 \%$ & - & - & - \\
\hline $\mathrm{MgO}$ & $0.82 \%$ & $0.14 \%$ & $0.75 \%$ & $0.22 \%$ \\
\hline $\mathrm{MnO}$ & - & $1.58 \%$ & $6.82 \%$ & $1.74 \%$ \\
\hline $\mathrm{Na}_{2} \mathrm{O}$ & $12.97 \%$ & $10.96 \%$ & $29.80 \%$ & $19.52 \%$ \\
\hline $\mathrm{NiO}$ & $3.71 \%$ & $0.86 \%$ & $4.29 \%$ & $1.41 \%$ \\
\hline $\mathrm{P}_{2} \mathrm{O}_{5}$ & $9.60 \%$ & $4.51 \%$ & $8.83 \%$ & $12.04 \%$ \\
\hline $\mathrm{PbO}$ & $0.48 \%$ & $0.81 \%$ & $0.49 \%$ & $1.43 \%$ \\
\hline $\mathrm{SO}_{3}$ & $0.91 \%$ & $0.83 \%$ & $1.58 \%$ & $0.81 \%$ \\
\hline $\mathrm{SiO}_{2}$ & $12.04 \%$ & $9.20 \%$ & $4.35 \%$ & $9.56 \%$ \\
\hline $\mathrm{SrO}$ & - & $0.63 \%$ & $0.29 \%$ & $0.65 \%$ \\
\hline $\mathrm{ThO}_{2}$ & $0.25 \%$ & $0.18 \%$ & - & - \\
\hline $\mathrm{TiO}_{2}$ & $0.30 \%$ & - & - & - \\
\hline $\mathrm{Tl}_{2} \mathrm{O}$ & - & & $0.12 \%$ & \\
\hline $\mathrm{UO}_{3}$ & $3.48 \%^{(3)}$ & $6.75 \%$ & $3.23 \%$ & $10.82 \%$ \\
\hline $\mathrm{ZnO}$ & $0.31 \%$ & - & - & - \\
\hline $\mathrm{ZrO}_{2}$ & $0.40 \%$ & $0.35 \%$ & $0.27 \%$ & $0.32 \%$ \\
\hline TOTAL & $100.0 \%$ & $99.56 \%$ & $99.16 \%$ & $99.66 \%$ \\
\hline
\end{tabular}

(1) Minor oxides (i.e., $<0.1 \mathrm{wt} \%$ ) omitted.

(2) - indicates empty data field.

${ }^{(3)} \mathrm{U}_{3} \mathrm{O}_{8}$ for Bi-limited waste. 
Table 2. Compositional Summary (wt\% Oxide Basis) of the HLW Simulants.

\begin{tabular}{|c|c|c|c|c|}
\hline Oxide & $\begin{array}{c}\text { Bi-Limited } \\
\text { Waste }[1]\end{array}$ & $\begin{array}{l}\text { WTP HLW } \\
\text { Glass Batch } \\
2394 \text { Waste }\end{array}$ & $\begin{array}{l}\text { WTP HLW } \\
\text { Glass Batch } \\
4006 \text { Waste }\end{array}$ & $\begin{array}{l}\text { WTP HLW } \\
\text { Glass Batch } \\
4098 \text { Waste }\end{array}$ \\
\hline $\mathrm{Al}_{2} \mathrm{O}_{3}$ & $23.31 \%$ & $25.38 \%$ & $15.06 \%$ & $29.33 \%$ \\
\hline $\mathrm{B}_{2} \mathrm{O}_{3}$ & $0.60 \%$ & $0.32 \%$ & $0.52 \%$ & - \\
\hline $\mathrm{BaO}$ & $0.02 \%$ & $0.13 \%$ & - & - \\
\hline $\mathrm{Bi}_{2} \mathrm{O}_{3}$ & $13.41 \%$ & $12.44 \%$ & $6.41 \%$ & $2.61 \%$ \\
\hline $\mathrm{CaO}$ & $1.67 \%$ & $4.55 \%$ & $1.78 \%$ & $2.93 \%$ \\
\hline $\mathrm{Cr}_{2} \mathrm{O}_{3}$ & $1.04 \%$ & $1.18 \%$ & $1.52 \%$ & $1.09 \%$ \\
\hline $\mathrm{F}$ & $1.64 \%$ & $1.03 \%$ & $0.85 \%$ & $0.64 \%$ \\
\hline $\mathrm{Fe}_{2} \mathrm{O}_{3}$ & $13.92 \%$ & $22.59 \%$ & $6.54 \%$ & $8.45 \%$ \\
\hline $\mathrm{K}_{2} \mathrm{O}$ & $0.92 \%$ & $0.16 \%$ & $5.44 \%$ & $0.66 \%$ \\
\hline $\mathrm{La}_{2} \mathrm{O}_{3}$ & - & - & $1.83 \%$ & $0.62 \%$ \\
\hline $\mathrm{Li}_{2} \mathrm{O}$ & $0.32 \%$ & - & - & - \\
\hline $\mathrm{MgO}$ & $0.85 \%$ & $0.16 \%$ & $0.79 \%$ & $0.25 \%$ \\
\hline $\mathrm{MnO}$ & - & $1.70 \%$ & $7.11 \%$ & $1.96 \%$ \\
\hline $\mathrm{Na}_{2} \mathrm{O}$ & $13.47 \%$ & $11.83 \%$ & $31.06 \%$ & $21.98 \%$ \\
\hline $\mathrm{NiO}$ & $3.85 \%$ & $0.92 \%$ & $4.47 \%$ & $1.59 \%$ \\
\hline $\mathrm{P}_{2} \mathrm{O}_{5}$ & $9.97 \%$ & $4.87 \%$ & $9.21 \%$ & $13.55 \%$ \\
\hline $\mathrm{PbO}$ & $0.50 \%$ & $0.88 \%$ & $0.51 \%$ & $1.61 \%$ \\
\hline $\mathrm{SO}_{3}$ & $0.95 \%$ & $0.89 \%$ & $1.65 \%$ & $0.91 \%$ \\
\hline $\mathrm{SiO}_{2}$ & $12.51 \%$ & $9.93 \%$ & $4.53 \%$ & $10.76 \%$ \\
\hline $\mathrm{SrO}$ & - & $0.68 \%$ & $0.30 \%$ & $0.73 \%$ \\
\hline $\mathrm{TiO}_{2}$ & $0.31 \%$ & - & - & - \\
\hline $\mathrm{Tl}_{2} \mathrm{O}$ & - & - & $0.13 \%$ & - \\
\hline $\mathrm{ZnO}$ & $0.32 \%$ & - & - & - \\
\hline $\mathrm{ZrO}_{2}$ & $0.42 \%$ & $0.38 \%$ & $0.28 \%$ & $0.36 \%$ \\
\hline TOTAL & $100.0 \%$ & $100.0 \%$ & $100.0 \%$ & $100.0 \%$ \\
\hline $\mathrm{Bi}_{2} \mathrm{O}_{3} /$ WTP Contract Limit & 6.71 & 6.22 & 3.21 & 1.30 \\
\hline $\mathrm{P}_{2} \mathrm{O}_{5} /$ WTP Contract Limit & 3.32 & 1.62 & 3.07 & 4.52 \\
\hline $\mathrm{Bi}_{2} \mathrm{O}_{3} / \mathrm{P}_{2} \mathrm{O}_{5}$ & 1.35 & 2.56 & 0.70 & 0.19 \\
\hline
\end{tabular}

- Empty data field. 
Table 3. HLW Canister Centerline Cooling Temperature Profile [13].

\begin{tabular}{|c|c|c|c|}
\hline Segment & $\begin{array}{c}\text { Time } \\
(\mathbf{m i n})\end{array}$ & $\begin{array}{c}\text { Start } \\
\text { Temperature } \\
\left({ }^{\circ} \mathbf{C}\right)\end{array}$ & $\begin{array}{c}\text { Rate } \\
\left({ }^{\circ} \mathbf{C} / \mathbf{m i n}\right)\end{array}$ \\
\hline 1 & $0-45$ & 1050 & -1.556 \\
\hline 2 & $45-107$ & 980 & -0.806 \\
\hline 3 & $107-200$ & 930 & -0.591 \\
\hline 4 & $200-329$ & 875 & -0.388 \\
\hline 5 & $329-527$ & 825 & -0.253 \\
\hline 6 & $527-707$ & 775 & -0.278 \\
\hline 7 & $707-1776$ & 725 & -0.304 \\
\hline
\end{tabular}


Table 4. Target Compositions of HLW Glasses Previously Developed for Bi-Limited Waste [1, 3].

\begin{tabular}{|c|c|c|c|}
\hline Glass ID & HLW-E-Bi6 & HLW-Bi-F3 & HLW-Bi-F9 \\
\hline Waste Loading ( $\mathrm{wt} \%)$ & $50 \mathrm{wt} \%$ & $50 \mathrm{wt} \%$ & $50 \mathrm{wt} \%$ \\
\hline Data Type & Target (wt\%) & Target (wt\%) & Target $(\mathrm{wt} \%)$ \\
\hline $\mathrm{Al}_{2} \mathrm{O}_{3}$ & 11.66 & 11.66 & 16.66 \\
\hline $\mathrm{B}_{2} \mathrm{O}_{3}$ & 11.30 & 10.30 & 16.30 \\
\hline $\mathrm{BaO}$ & 0.01 & 0.01 & 0.01 \\
\hline $\mathrm{Bi}_{2} \mathrm{O}_{3}$ & 6.71 & 6.71 & 6.71 \\
\hline $\mathrm{CaO}$ & 0.84 & 0.84 & 0.84 \\
\hline $\mathrm{Cr}_{2} \mathrm{O}_{3}$ & 0.52 & 0.52 & 0.52 \\
\hline $\mathrm{F}$ & 0.82 & 0.82 & 0.82 \\
\hline $\mathrm{Fe}_{2} \mathrm{O}_{3}$ & 6.96 & 6.96 & 6.96 \\
\hline $\mathrm{K}_{2} \mathrm{O}$ & 0.46 & 0.46 & 0.46 \\
\hline $\mathrm{La}_{2} \mathrm{O}_{3}$ & 0.00 & 0.00 & 0.00 \\
\hline $\mathrm{Li}_{2} \mathrm{O}$ & 0.16 & 0.16 & 5.16 \\
\hline $\mathrm{MgO}$ & 0.43 & 0.43 & 0.43 \\
\hline $\mathrm{MnO}$ & 0.00 & 0.00 & 0.00 \\
\hline $\mathrm{Na}_{2} \mathrm{O}$ & 15.74 & 18.74 & 7.74 \\
\hline $\mathrm{Nd}_{2} \mathrm{O}_{3}$ & 0.00 & 0.00 & 0.00 \\
\hline $\mathrm{NiO}$ & 1.93 & 1.93 & 1.93 \\
\hline $\mathrm{P}_{2} \mathrm{O}_{5}$ & 4.99 & 4.99 & 4.99 \\
\hline $\mathrm{PbO}$ & 0.25 & 0.25 & 0.25 \\
\hline $\mathrm{SiO}_{2}$ & 36.26 & 34.26 & 29.26 \\
\hline $\mathrm{SrO}$ & 0.00 & 0.00 & 0.00 \\
\hline $\mathrm{TiO}_{2}$ & 0.16 & 0.16 & 0.16 \\
\hline $\mathrm{SO}_{3}$ & 0.48 & 0.48 & 0.48 \\
\hline $\mathrm{ZnO}$ & 0.16 & 0.16 & 0.16 \\
\hline $\mathrm{ZrO}_{2}$ & 0.21 & 0.21 & 0.21 \\
\hline Sum & 100.00 & 100.00 & 100.00 \\
\hline
\end{tabular}


The Catholic University of America Vitreous State Laboratory
Development of High Waste Loading HLW Glasses for High Bismuth Phosphate Wastes Final Report, VSL-12R2550-1, Rev. 0

Table 5a. Target and XRF Analysis of Glass Compositions for Waste Batch 2394 (wt\%). $\mathrm{B}_{2} \mathrm{O}_{3}, \mathrm{Li}_{2} \mathrm{O}$ and $\mathrm{F}$ in $\mathrm{XRF}$ column are target values unless otherwise noted.

\begin{tabular}{|c|c|c|c|c|c|c|}
\hline Sample ID & \multicolumn{2}{|c|}{ HWBi2394-1 } & \multicolumn{2}{|c|}{ HWBi2394-2 } & \multicolumn{2}{|c|}{ НWBi2394-3 } \\
\hline $\begin{array}{c}\text { Waste } \\
\text { loading }\end{array}$ & \multicolumn{2}{|c|}{50} & \multicolumn{2}{|c|}{50} & \multicolumn{2}{|c|}{45} \\
\hline Data Type & Target & XRF & Target & XRF & Target & XRF \\
\hline $\mathrm{Al}_{2} \mathrm{O}_{3}$ & 12.69 & 12.59 & 12.69 & 12.37 & 11.42 & 11.24 \\
\hline $\mathrm{B}_{2} \mathrm{O}_{3}$ & 15.16 & 15.16 & 18.16 & 18.16 & 18.14 & $18.87^{*}$ \\
\hline $\mathrm{BaO}$ & 0.07 & $0.00^{\$ \$}$ & 0.07 & $0.00^{\$ \$}$ & 0.06 & $0.00^{\$ \$}$ \\
\hline $\mathrm{Bi}_{2} \mathbf{O}_{3}$ & 6.22 & 6.50 & 6.22 & 6.88 & 5.60 & 6.00 \\
\hline Cl & 0.00 & 0.01 & 0.00 & 0.02 & 0.00 & 0.02 \\
\hline $\mathrm{CaO}$ & 2.27 & 2.25 & 2.27 & 2.37 & 2.05 & 2.08 \\
\hline $\mathrm{Cr}_{2} \mathrm{O}_{3}$ & 0.59 & 0.55 & 0.59 & 0.59 & 0.53 & 0.50 \\
\hline $\mathbf{F}$ & 0.51 & $\mathrm{NA}$ & 0.51 & $\mathrm{NA}$ & 0.46 & 0.46 \\
\hline $\mathrm{Fe}_{2} \mathrm{O}_{3}$ & 11.29 & 11.49 & 11.29 & 11.37 & 10.16 & 10.13 \\
\hline $\mathrm{K}_{2} \mathrm{O}$ & 0.08 & 0.12 & 0.08 & 0.12 & 0.07 & 0.09 \\
\hline $\mathrm{La}_{\mathbf{2}} \mathbf{O}_{\mathbf{3}}$ & 0.00 & 0.00 & 0.00 & 0.00 & 0.00 & 0.00 \\
\hline $\mathbf{L i}_{2} \mathbf{O}$ & 4.00 & 4.00 & 6.00 & 6.00 & 6.00 & $5.99 *$ \\
\hline MgO & 0.08 & 0.12 & 0.08 & 0.10 & 0.07 & 0.07 \\
\hline MnO & 0.85 & 0.85 & 0.85 & 0.84 & 0.77 & 0.77 \\
\hline $\mathrm{Na}_{2} \mathrm{O}$ & 10.91 & 11.62 & 5.91 & 5.86 & 5.32 & 5.41 \\
\hline $\mathrm{NiO}$ & 0.46 & 0.49 & 0.46 & 0.50 & 0.42 & 0.46 \\
\hline $\mathrm{P}_{2} \mathrm{O}_{5}$ & 2.43 & 3.01 & 2.43 & 3.07 & 2.19 & 2.25 \\
\hline PbO & 0.44 & 0.49 & 0.44 & 0.53 & 0.40 & 0.46 \\
\hline $\mathrm{SiO}_{2}$ & 30.97 & 29.96 & 30.97 & 30.33 & 35.47 & 34.32 \\
\hline SrO & 0.34 & 0.32 & 0.34 & 0.35 & 0.30 & 0.31 \\
\hline $\mathrm{TiO}_{2}$ & 0.00 & 0.03 & 0.00 & 0.00 & 0.00 & 0.02 \\
\hline $\mathrm{Tl}_{2} \mathrm{O}^{\$}$ & 0.00 & 0.00 & 0.00 & 0.01 & 0.00 & 0.00 \\
\hline $\mathrm{SO}_{3}$ & 0.45 & 0.26 & 0.45 & 0.33 & 0.40 & 0.38 \\
\hline $\mathrm{ZrO}_{2}$ & 0.19 & 0.19 & 0.19 & 0.22 & 0.17 & 0.17 \\
\hline Sum & 100.00 & 100.00 & 100.00 & 99.99 & 100.00 & 99.99 \\
\hline
\end{tabular}


Table 5a. Target and XRF Analysis of Glass Compositions for Waste Batch 2394 (wt\%). $\mathrm{B}_{2} \mathrm{O}_{3}, \mathrm{Li}_{2} \mathrm{O}$ and $\mathrm{F}$ in $\mathrm{XRF}$ column are target values unless otherwise noted (continued).

\begin{tabular}{|c|c|c|c|c|}
\hline Sample ID & \multicolumn{2}{|c|}{ HWBi2394-3r } & \multicolumn{2}{|c|}{ HWBi2394-4 } \\
\hline $\begin{array}{l}\text { Waste } \\
\text { loading }\end{array}$ & \multicolumn{2}{|c|}{45} & \multicolumn{2}{|c|}{40} \\
\hline Data Type & Target & XRF & Target & XRF \\
\hline $\mathrm{Al}_{2} \mathrm{O}_{3}$ & 11.42 & 11.04 & 10.15 & 10.21 \\
\hline $\mathrm{B}_{2} \mathrm{O}_{3}$ & 18.14 & 18.14 & 18.13 & 18.13 \\
\hline $\mathrm{BaO}$ & 0.06 & 0.07 & 0.05 & $0.00^{\$ \$}$ \\
\hline $\mathrm{Bi}_{2} \mathbf{O}_{3}$ & 5.60 & 6.55 & 4.98 & 5.60 \\
\hline Cl & 0.00 & 0.02 & 0.00 & 0.02 \\
\hline $\mathrm{CaO}$ & 2.05 & 2.15 & 1.82 & 1.86 \\
\hline $\mathrm{Cr}_{2} \mathrm{O}_{3}$ & 0.53 & 0.55 & 0.47 & 0.49 \\
\hline $\mathbf{F}$ & 0.46 & NA & 0.41 & NA \\
\hline $\mathrm{Fe}_{2} \mathrm{O}_{3}$ & 10.16 & 10.67 & 9.04 & 9.13 \\
\hline $\mathbf{K}_{2} \mathrm{O}$ & 0.07 & 0.08 & 0.06 & 0.10 \\
\hline $\mathrm{La}_{2} \mathrm{O}_{3}$ & 0.00 & 0.00 & 0.00 & 0.00 \\
\hline $\mathrm{Li}_{2} \mathrm{O}$ & 6.00 & 6.00 & 6.00 & 6.00 \\
\hline MgO & 0.07 & 0.08 & 0.06 & 0.07 \\
\hline $\mathrm{MnO}$ & 0.77 & 0.76 & 0.68 & 0.72 \\
\hline $\mathrm{Na}_{2} \mathrm{O}$ & 5.32 & 5.14 & 4.73 & 4.78 \\
\hline $\mathrm{NiO}$ & 0.42 & 0.48 & 0.37 & 0.44 \\
\hline $\mathrm{P}_{2} \mathrm{O}_{5}$ & 2.19 & 2.45 & 1.95 & 2.22 \\
\hline $\mathrm{PbO}$ & 0.40 & 0.49 & 0.35 & 0.43 \\
\hline $\mathrm{SiO}_{2}$ & 35.47 & 34.50 & 39.97 & 39.01 \\
\hline SrO & 0.30 & 0.30 & 0.27 & 0.27 \\
\hline $\mathrm{TiO}_{2}$ & 0.00 & 0.02 & 0.00 & 0.02 \\
\hline $\mathrm{Tl}_{2} \mathrm{O}^{\$}$ & 0.00 & 0.00 & 0.00 & 0.00 \\
\hline $\mathrm{SO}_{3}$ & 0.40 & 0.30 & 0.36 & 0.34 \\
\hline $\mathrm{ZrO}_{2}$ & 0.17 & 0.21 & 0.15 & 0.17 \\
\hline Sum & 100.00 & 99.99 & 100.00 & 100.00 \\
\hline
\end{tabular}


The Catholic University of America Vitreous State Laboratory
Development of High Waste Loading HLW Glasses for High Bismuth Phosphate Wastes Final Report, VSL-12R2550-1, Rev. 0

Table 5b. Target and XRF Analysis of Glass Compositions for Waste Batch 4098 (wt\%). $\mathrm{B}_{2} \mathrm{O}_{3}, \mathrm{Li}_{2} \mathrm{O}$ and $\mathrm{F}$ in XRF column are target values unless otherwise noted.

\begin{tabular}{|c|c|c|c|c|c|c|}
\hline Sample ID & \multicolumn{2}{|c|}{ HWBi4098-1 } & \multicolumn{2}{|c|}{ HWBi4098-2 } & \multicolumn{2}{|c|}{ HWBi4098-3 } \\
\hline Waste & \multicolumn{2}{|c|}{50} & \multicolumn{2}{|c|}{45} & \multicolumn{2}{|c|}{45} \\
\hline Data Type & Target & XRF & Target & XRF & Target & XRF \\
\hline $\mathrm{Al}_{2} \mathrm{O}_{3}$ & 18.66 & 18.06 & 20.20 & 19.27 & 19.20 & 18.94 \\
\hline $\mathbf{B}_{2} \mathbf{O}_{3}$ & 17.00 & 17.00 & 19.00 & 19.00 & 18.00 & 18.00 \\
\hline $\mathrm{BaO}$ & 0.00 & 0.00 & 0.00 & 0.00 & 0.00 & 0.00 \\
\hline $\mathrm{Bi}_{2} \mathrm{O}_{3}$ & 1.30 & 1.35 & 1.17 & 1.26 & 1.17 & 1.26 \\
\hline Cl & 0.00 & 0.03 & 0.00 & 0.04 & 0.00 & 0.02 \\
\hline $\mathrm{CaO}$ & 1.47 & 1.43 & 4.32 & 4.36 & 6.32 & 6.40 \\
\hline $\mathrm{Cr}_{2} \mathrm{O}_{3}$ & 0.54 & 0.49 & 0.49 & 0.48 & 0.49 & 0.45 \\
\hline $\mathbf{F}$ & 0.32 & NA & 0.29 & NA & 0.29 & $\mathrm{NA}$ \\
\hline $\mathrm{Fe}_{2} \mathrm{O}_{3}$ & 4.23 & 4.09 & 3.80 & 3.84 & 3.80 & 3.94 \\
\hline $\mathbf{K}_{2} \mathbf{O}$ & 0.33 & 0.40 & 0.30 & 0.36 & 0.30 & 0.32 \\
\hline $\mathrm{La}_{2} \mathrm{O}_{3}$ & 0.31 & 0.39 & 0.28 & 0.40 & 0.28 & 0.34 \\
\hline $\mathbf{L i}_{2} \mathbf{O}$ & 3.00 & 3.00 & 4.00 & 4.00 & 4.00 & 4.00 \\
\hline MgO & 0.13 & 0.15 & 0.11 & 0.09 & 0.11 & 0.13 \\
\hline MnO & 0.98 & 0.95 & 0.88 & 0.86 & 0.88 & 0.90 \\
\hline $\mathrm{Na}_{2} \mathrm{O}$ & 10.99 & 12.07 & 9.89 & 10.34 & 9.89 & 10.06 \\
\hline $\mathrm{NiO}$ & 0.79 & 0.81 & 0.72 & 0.81 & 0.72 & 0.82 \\
\hline $\mathrm{P}_{2} \mathrm{O}_{5}$ & 6.77 & 8.32 & 6.10 & 7.58 & 6.10 & 6.45 \\
\hline $\mathrm{PbO}$ & 0.80 & 0.74 & 0.72 & 0.74 & 0.72 & 0.72 \\
\hline $\mathrm{SiO}_{2}$ & 31.38 & 29.73 & 26.84 & 25.70 & 26.84 & 26.38 \\
\hline SrO & 0.36 & 0.34 & 0.33 & 0.33 & 0.33 & 0.32 \\
\hline $\mathrm{TiO}_{2}$ & 0.00 & 0.02 & 0.00 & 0.00 & 0.00 & 0.02 \\
\hline $\mathrm{Tl}_{2} \mathrm{O}^{\$}$ & 0.00 & 0.00 & 0.00 & 0.00 & 0.00 & 0.00 \\
\hline $\mathrm{SO}_{3}$ & 0.45 & 0.43 & 0.41 & 0.37 & 0.41 & 0.34 \\
\hline $\mathrm{ZrO}_{2}$ & 0.18 & 0.20 & 0.16 & 0.19 & 0.16 & 0.19 \\
\hline Sum & 100.00 & 100.00 & 100.00 & 100.00 & 100.00 & 100.00 \\
\hline
\end{tabular}

s: Reported as $\mathrm{Tl}_{2} \mathrm{O}_{3}$ by XRF and converted

NA: Not analyzed 
The Catholic University of America Vitreous State Laboratory
Development of High Waste Loading HLW Glasses for High Bismuth Phosphate Wastes Final Report, VSL-12R2550-1, Rev. 0

Table 5b. Target and XRF Analysis of Glass Compositions for Waste Batch 4098 (wt \%). $\mathrm{B}_{2} \mathrm{O}_{3}, \mathrm{Li}_{2} \mathrm{O}$ and $\mathrm{F}$ in XRF column are target values unless otherwise noted (continued).

\begin{tabular}{|c|c|c|c|c|c|c|}
\hline Sample ID & \multicolumn{2}{|c|}{ HWBi4098-4 } & \multicolumn{2}{|c|}{ HWBi4098-5 } & \multicolumn{2}{|c|}{ HWBi4098-6 } \\
\hline Waste & \multicolumn{2}{|c|}{45} & \multicolumn{2}{|c|}{45} & \multicolumn{2}{|c|}{40} \\
\hline Data Type & Target & XRF & Target & XRF & Target & XRF \\
\hline $\mathrm{Al}_{2} \mathrm{O}_{3}$ & 17.20 & 17.19 & 13.20 & 13.31 & 17.73 & 17.39 \\
\hline $\mathrm{B}_{2} \mathrm{O}_{3}$ & 17.00 & 17.00 & 17.00 & 17.00 & 17.00 & $17.15^{*}$ \\
\hline $\mathrm{BaO}$ & 0.00 & 0.00 & 0.00 & 0.00 & 0.00 & 0.00 \\
\hline $\mathrm{Bi}_{2} \mathrm{O}_{3}$ & 1.17 & 1.36 & 1.17 & 1.26 & 1.04 & 1.17 \\
\hline $\mathrm{Cl}$ & 0.00 & 0.03 & 0.00 & 0.03 & 0.00 & 0.03 \\
\hline $\mathrm{CaO}$ & 1.32 & 1.42 & 1.32 & 1.32 & 1.17 & 1.18 \\
\hline $\mathrm{Cr}_{2} \mathrm{O}_{3}$ & 0.49 & 0.47 & 0.49 & 0.43 & 0.44 & 0.39 \\
\hline F & 0.29 & NA & 0.29 & NA & 0.26 & 0.26 \\
\hline $\mathrm{Fe}_{2} \mathrm{O}_{3}$ & 3.80 & 3.97 & 3.80 & 3.95 & 3.38 & 3.43 \\
\hline $\mathrm{K}_{2} \mathrm{O}$ & 0.30 & 0.31 & 0.30 & 0.31 & 0.26 & 0.29 \\
\hline $\mathrm{La}_{2} \mathrm{O}_{3}$ & 0.28 & 0.35 & 0.28 & 0.30 & 0.25 & 0.26 \\
\hline $\mathbf{L i}_{2} \mathbf{O}$ & 3.00 & 3.00 & 3.00 & 3.00 & 4.00 & $4.01 *$ \\
\hline MgO & 0.11 & 0.12 & 0.11 & 0.13 & 0.10 & 0.13 \\
\hline $\mathrm{MnO}$ & 0.88 & 0.92 & 0.88 & 0.86 & 0.78 & 0.78 \\
\hline $\mathrm{Na}_{2} \mathrm{O}$ & 9.89 & 9.56 & 9.89 & 9.86 & 8.79 & 8.73 \\
\hline $\mathrm{NiO}$ & 0.72 & 0.82 & 0.72 & 0.77 & 0.64 & 0.70 \\
\hline $\mathrm{P}_{2} \mathrm{O}_{5}$ & 6.10 & 6.47 & 6.10 & 6.39 & 5.42 & 5.94 \\
\hline PbO & 0.72 & 0.79 & 0.72 & 0.73 & 0.64 & 0.66 \\
\hline $\mathrm{SiO}_{2}$ & 35.84 & 35.33 & 39.84 & 39.38 & 37.30 & 36.66 \\
\hline SrO & 0.33 & 0.34 & 0.33 & 0.32 & 0.29 & 0.29 \\
\hline $\mathrm{TiO}_{2}$ & 0.00 & 0.00 & 0.00 & 0.02 & 0.00 & 0.02 \\
\hline $\mathrm{Tl}_{2} \mathrm{O}^{\$}$ & 0.00 & 0.00 & 0.00 & 0.00 & 0.00 & 0.00 \\
\hline $\mathrm{SO}_{3}$ & 0.41 & 0.35 & 0.41 & 0.41 & 0.36 & 0.35 \\
\hline $\mathrm{ZrO}_{2}$ & 0.16 & 0.20 & 0.16 & 0.20 & 0.14 & 0.18 \\
\hline Sum & 100.00 & 100.00 & 100.00 & 100.00 & 100.00 & 100.00 \\
\hline
\end{tabular}

*: $\mathrm{B}_{2} \mathrm{O}_{3}$ and $\mathrm{Li}_{2} \mathrm{O}$ from DCP analysis

$\$$ : Reported as $\mathrm{Tl}_{2} \mathrm{O}_{3}$ by XRF and converted

NA: Not analyzed 
The Catholic University of America Vitreous State Laboratory
Development of High Waste Loading HLW Glasses for High Bismuth Phosphate Wastes Final Report, VSL-12R2550-1, Rev. 0

Table 5b. Target and XRF Analysis of Glass Compositions for Waste Batch 4098 (wt \%). $\mathrm{B}_{2} \mathrm{O}_{3}, \mathrm{Li}_{2} \mathrm{O}$ and $\mathrm{F}$ in XRF column are target values unless otherwise noted (continued).

\begin{tabular}{|c|c|c|c|c|c|c|}
\hline Sample ID & \multicolumn{2}{|c|}{ HWBi4098-7 } & \multicolumn{2}{|c|}{ HWBi4098-8 } & \multicolumn{2}{|c|}{ HWBi4098-9 } \\
\hline Waste & \multicolumn{2}{|c|}{45} & \multicolumn{2}{|c|}{40} & \multicolumn{2}{|c|}{40} \\
\hline Data Type & Target & XRF & Target & XRF & Target & XRF \\
\hline $\mathrm{Al}_{2} \mathrm{O}_{3}$ & 20.20 & 19.85 & 20.73 & 20.03 & 11.73 & 11.56 \\
\hline $\mathrm{B}_{2} \mathrm{O}_{3}$ & 19.00 & $18.95^{*}$ & 20.00 & 20.00 & 18.00 & 18.00 \\
\hline $\mathrm{BaO}$ & 0.00 & 0.00 & 0.00 & 0.00 & 0.00 & 0.00 \\
\hline $\mathrm{Bi}_{2} \mathrm{O}_{3}$ & 1.17 & 1.30 & 1.04 & 1.26 & 1.04 & 1.22 \\
\hline $\mathrm{Cl}$ & 0.00 & 0.02 & 0.00 & 0.04 & 0.00 & 0.02 \\
\hline $\mathrm{CaO}$ & 1.32 & 1.34 & 1.17 & 1.28 & 1.17 & 1.27 \\
\hline $\mathrm{Cr}_{2} \mathrm{O}_{3}$ & 0.49 & 0.45 & 0.44 & 0.46 & 0.44 & 0.46 \\
\hline F & 0.29 & 0.29 & 0.26 & NA & 0.26 & NA \\
\hline $\mathrm{Fe}_{2} \mathrm{O}_{3}$ & 3.80 & 3.96 & 3.38 & 3.61 & 3.38 & 3.51 \\
\hline $\mathrm{K}_{2} \mathrm{O}$ & 0.30 & 0.34 & 0.26 & 0.26 & 0.26 & 0.27 \\
\hline $\mathrm{La}_{2} \mathrm{O}_{3}$ & 0.28 & 0.28 & 0.25 & 0.37 & 0.25 & 0.33 \\
\hline $\mathbf{L i}_{2} \mathbf{O}$ & 5.00 & $5.09^{*}$ & 5.00 & 5.00 & 4.00 & 4.00 \\
\hline MgO & 0.11 & 0.13 & 0.10 & 0.13 & 0.10 & 0.10 \\
\hline $\mathrm{MnO}$ & 0.88 & 0.90 & 0.78 & 0.84 & 0.78 & 0.85 \\
\hline $\mathrm{Na}_{2} \mathrm{O}$ & 9.89 & 10.09 & 8.79 & 8.21 & 8.79 & 8.16 \\
\hline $\mathrm{NiO}$ & 0.72 & 0.76 & 0.64 & 0.76 & 0.64 & 0.76 \\
\hline $\mathrm{P}_{2} \mathrm{O}_{5}$ & 6.10 & 6.43 & 5.42 & 6.23 & 5.42 & 6.34 \\
\hline PbO & 0.72 & 0.75 & 0.64 & 0.75 & 0.64 & 0.71 \\
\hline $\mathrm{SiO}_{2}$ & 28.84 & 28.19 & 30.30 & 29.88 & 42.30 & 41.56 \\
\hline SrO & 0.33 & 0.34 & 0.29 & 0.32 & 0.29 & 0.32 \\
\hline $\mathrm{TiO}_{2}$ & 0.00 & 0.00 & 0.00 & 0.02 & 0.00 & 0.03 \\
\hline $\mathrm{Tl}_{2} \mathrm{O}^{\$}$ & 0.00 & 0.00 & 0.00 & 0.00 & 0.00 & 0.00 \\
\hline $\mathrm{SO}_{3}$ & 0.41 & 0.35 & 0.36 & 0.40 & 0.36 & 0.35 \\
\hline $\mathrm{ZrO}_{2}$ & 0.16 & 0.20 & 0.14 & 0.19 & 0.14 & 0.18 \\
\hline Sum & 100.00 & 100.00 & 100.00 & 99.99 & 100.00 & 99.99 \\
\hline
\end{tabular}

*: $\mathrm{B}_{2} \mathrm{O}_{3}$ and $\mathrm{Li}_{2} \mathrm{O}$ from DCP analysis

$\$$ : Reported as $\mathrm{Tl}_{2} \mathrm{O}_{3}$ by XRF and converted

NA: Not analyzed 
Table 5b. Target and XRF Analysis of Glass Compositions for Waste Batch $4098(w \mathbf{t} \%)$. $\mathrm{B}_{2} \mathrm{O}_{3}, \mathrm{Li}_{2} \mathrm{O}$ and $\mathrm{F}$ in XRF column are target values unless otherwise noted (continued).

\begin{tabular}{|c|c|c|}
\hline Sample ID & \multicolumn{2}{|c|}{ HWBi4098-10 } \\
\hline $\begin{array}{c}\text { Waste } \\
\text { loading }\end{array}$ & \multicolumn{2}{|c|}{35} \\
\hline Data Type & Target & XRF \\
\hline $\mathrm{Al}_{2} \mathrm{O}_{3}$ & 20.27 & 19.91 \\
\hline $\mathrm{B}_{2} \mathrm{O}_{3}$ & 19.00 & 19.00 \\
\hline $\mathrm{BaO}$ & 0.00 & 0.00 \\
\hline $\mathrm{Bi}_{2} \mathrm{O}_{3}$ & 0.91 & 1.12 \\
\hline $\mathrm{Cl}$ & 0.00 & 0.04 \\
\hline $\mathrm{CaO}$ & 1.03 & 1.14 \\
\hline $\mathrm{Cr}_{2} \mathrm{O}_{3}$ & 0.38 & 0.36 \\
\hline $\mathbf{F}$ & 0.22 & NA \\
\hline $\mathrm{Fe}_{2} \mathrm{O}_{3}$ & 2.96 & 3.04 \\
\hline $\mathrm{K}_{2} \mathrm{O}$ & 0.23 & 0.22 \\
\hline $\mathrm{La}_{2} \mathrm{O}_{3}$ & 0.22 & 0.33 \\
\hline $\mathrm{Li}_{2} \mathrm{O}$ & 5.00 & 5.00 \\
\hline MgO & 0.09 & 0.12 \\
\hline MnO & 0.69 & 0.70 \\
\hline $\mathrm{Na}_{2} \mathrm{O}$ & 7.69 & 7.36 \\
\hline $\mathrm{NiO}$ & 0.56 & 0.63 \\
\hline $\mathrm{P}_{2} \mathrm{O}_{5}$ & 4.74 & 5.48 \\
\hline PbO & 0.56 & 0.62 \\
\hline $\mathrm{SiO}_{2}$ & 34.77 & 34.16 \\
\hline SrO & 0.25 & 0.28 \\
\hline $\mathrm{TiO}_{2}$ & 0.00 & 0.01 \\
\hline $\mathrm{Tl}_{2} \mathrm{O}^{\$}$ & 0.00 & 0.00 \\
\hline $\mathrm{SO}_{3}$ & 0.32 & 0.33 \\
\hline $\mathrm{ZrO}_{2}$ & 0.12 & 0.17 \\
\hline Sum & 100.00 & 99.99 \\
\hline
\end{tabular}

s: Reported as $\mathrm{Tl}_{2} \mathrm{O}_{3}$ by XRF and converted NA: Not analyzed 
The Catholic University of America Vitreous State Laboratory
Development of High Waste Loading HLW Glasses for High Bismuth Phosphate Wastes Final Report, VSL-12R2550-1, Rev. 0

Table 5c. Target and XRF Analysis of Glass Compositions for Waste Batch 4006 (wt\%). $\mathrm{B}_{2} \mathrm{O}_{3}, \mathrm{Li}_{2} \mathrm{O}$ and $\mathrm{F}$ in XRF column are target values unless otherwise noted.

\begin{tabular}{|c|c|c|c|c|c|c|}
\hline Sample ID & \multicolumn{2}{|c|}{ HWBi4006-1 } & \multicolumn{2}{|c|}{ HWBi4006-2 } & \multicolumn{2}{|c|}{ HWBi4006-3 } \\
\hline Waste loading & \multicolumn{2}{|c|}{50} & \multicolumn{2}{|c|}{45} & \multicolumn{2}{|c|}{45} \\
\hline Data Type & Target & XRF & Target & XRF & Target & XRF \\
\hline $\mathrm{Al}_{2} \mathrm{O}_{3}$ & 15.53 & 15.10 & 14.78 & 14.39 & 14.78 & 14.47 \\
\hline $\mathbf{B}_{2} \mathbf{O}_{3}$ & 15.26 & 15.26 & 17.23 & 17.23 & 18.23 & 18.23 \\
\hline $\mathrm{BaO}$ & 0.00 & 0.00 & 0.00 & 0.00 & 0.00 & 0.00 \\
\hline $\mathrm{Bi}_{2} \mathrm{O}_{3}$ & 3.21 & 3.45 & 2.89 & 3.22 & 2.89 & 3.15 \\
\hline Cl & 0.00 & 0.03 & 0.00 & 0.03 & 0.00 & 0.03 \\
\hline $\mathrm{CaO}$ & 0.89 & 0.90 & 0.80 & 0.85 & 0.80 & 0.83 \\
\hline $\mathrm{Cr}_{2} \mathrm{O}_{3}$ & 0.76 & 0.71 & 0.69 & 0.70 & 0.69 & 0.66 \\
\hline $\mathbf{F}$ & 0.42 & NA & 0.38 & NA & 0.38 & NA \\
\hline $\mathrm{Fe}_{2} \mathrm{O}_{3}$ & 3.27 & 3.46 & 2.94 & 3.06 & 2.94 & 3.02 \\
\hline $\mathbf{K}_{2} \mathbf{O}$ & 2.72 & 2.67 & 2.45 & 2.56 & 2.45 & 2.52 \\
\hline $\mathrm{La}_{2} \mathbf{O}_{3}$ & 0.91 & 1.06 & 0.82 & 1.09 & 0.82 & 0.98 \\
\hline $\mathbf{L i}_{2} \mathbf{O}$ & 0.00 & 0.00 & 2.00 & 2.00 & 0.00 & 0.00 \\
\hline MgO & 0.39 & 0.32 & 0.35 & 0.27 & 0.35 & 0.30 \\
\hline MnO & 3.56 & 3.46 & 3.20 & 3.24 & 3.20 & 3.25 \\
\hline $\mathrm{Na}_{2} \mathrm{O}$ & 15.53 & 16.18 & 13.98 & 13.91 & 13.98 & 14.29 \\
\hline $\mathrm{NiO}$ & 2.24 & 2.39 & 2.01 & 2.26 & 2.01 & 2.20 \\
\hline $\mathbf{P}_{2} \mathbf{O}_{5}$ & 4.60 & 5.74 & 4.14 & 5.14 & 4.14 & 4.36 \\
\hline $\mathrm{PbO}$ & 0.26 & 0.26 & 0.23 & 0.27 & 0.23 & 0.27 \\
\hline $\mathrm{SiO}_{2}$ & 29.27 & 28.08 & 30.04 & 28.92 & 31.04 & 30.54 \\
\hline SrO & 0.15 & 0.15 & 0.14 & 0.14 & 0.14 & 0.14 \\
\hline $\mathrm{TiO}_{2}$ & 0.00 & 0.02 & 0.00 & 0.01 & 0.00 & 0.01 \\
\hline $\mathrm{Tl}_{2} \mathrm{O}^{\$}$ & 0.06 & 0.05 & 0.06 & 0.04 & 0.06 & 0.04 \\
\hline $\mathrm{SO}_{3}$ & 0.82 & 0.57 & 0.74 & 0.51 & 0.74 & 0.56 \\
\hline $\mathrm{ZrO}_{2}$ & 0.14 & 0.16 & 0.13 & 0.14 & 0.13 & 0.14 \\
\hline Sum & 100.00 & 100.00 & 100.00 & 99.99 & 100.00 & 100.00 \\
\hline
\end{tabular}

\$: Reported as $\mathrm{Tl}_{2} \mathrm{O}_{3}$ by XRF and converted

NA: Not analyzed 
Table 5c. Target and XRF Analysis of Glass Compositions for Waste Batch 4006 (wt\%). $\mathrm{B}_{2} \mathrm{O}_{3}, \mathrm{Li}_{2} \mathrm{O}$ and $\mathrm{F}$ in XRF column are target values unless otherwise noted (continued).

\begin{tabular}{|c|c|c|c|c|c|c|}
\hline Sample ID & \multicolumn{2}{|c|}{ HWBi4006-4 } & \multicolumn{2}{|c|}{ HWBi4006-5 } & \multicolumn{2}{|c|}{ HWBi4006-6 } \\
\hline Waste & \multicolumn{2}{|c|}{45} & \multicolumn{2}{|c|}{45} & \multicolumn{2}{|c|}{40} \\
\hline Data Type & Target & XRF & Target & XRF & Target & XRF \\
\hline $\mathrm{Al}_{2} \mathrm{O}_{3}$ & 6.78 & 6.75 & 6.78 & 6.94 & 14.02 & 13.79 \\
\hline $\mathrm{B}_{2} \mathrm{O}_{3}$ & 15.23 & $15.86^{*}$ & 10.23 & $10.69^{*}$ & 18.21 & 18.21 \\
\hline $\mathrm{BaO}$ & 0.00 & 0.00 & 0.00 & 0.00 & 0.00 & 0.00 \\
\hline $\mathrm{Bi}_{2} \mathrm{O}_{3}$ & 2.89 & 3.12 & 2.89 & 3.10 & 2.57 & 2.87 \\
\hline $\mathrm{Cl}$ & 0.00 & 0.02 & 0.00 & 0.02 & 0.00 & 0.03 \\
\hline $\mathrm{CaO}$ & 0.80 & 0.84 & 0.80 & 0.81 & 0.71 & 0.75 \\
\hline $\mathrm{Cr}_{2} \mathrm{O}_{3}$ & 0.69 & 0.67 & 0.69 & 0.68 & 0.61 & 0.61 \\
\hline $\mathbf{F}$ & 0.38 & 0.38 & 0.38 & 0.38 & 0.34 & $\mathrm{NA}$ \\
\hline $\mathrm{Fe}_{2} \mathrm{O}_{3}$ & 2.94 & 3.05 & 2.94 & 2.92 & 2.62 & 2.78 \\
\hline $\mathrm{K}_{2} \mathrm{O}$ & 2.45 & 2.46 & 2.45 & 2.44 & 2.17 & 2.30 \\
\hline $\mathrm{La}_{2} \mathrm{O}_{3}$ & 0.82 & 1.12 & 0.82 & 0.73 & 0.73 & 0.90 \\
\hline $\mathrm{Li}_{2} \mathrm{O}$ & 0.00 & $0.00^{*}$ & 0.00 & $0.00 *$ & 2.00 & 2.00 \\
\hline MgO & 0.35 & 0.27 & 0.35 & 0.29 & 0.31 & 0.25 \\
\hline MnO & 3.20 & 3.17 & 3.20 & 3.14 & 2.85 & 2.87 \\
\hline $\mathrm{Na}_{2} \mathrm{O}$ & 13.98 & 13.87 & 13.98 & 14.36 & 12.43 & 12.53 \\
\hline $\mathrm{NiO}$ & 2.01 & 2.19 & 2.01 & 2.24 & 1.79 & 2.04 \\
\hline $\mathrm{P}_{2} \mathrm{O}_{5}$ & 4.14 & 4.15 & 4.14 & 4.35 & 3.68 & 3.93 \\
\hline PbO & 0.23 & 0.26 & 0.23 & 0.26 & 0.21 & 0.26 \\
\hline $\mathrm{SiO}_{2}$ & 42.04 & 40.93 & 47.04 & 45.69 & 33.81 & 33.06 \\
\hline SrO & 0.14 & 0.14 & 0.14 & 0.14 & 0.12 & 0.13 \\
\hline $\mathrm{TiO}_{2}$ & 0.00 & 0.02 & 0.00 & 0.02 & 0.00 & 0.02 \\
\hline $\mathrm{Tl}_{2} \mathrm{O}^{\$}$ & 0.06 & 0.05 & 0.06 & 0.05 & 0.05 & 0.04 \\
\hline $\mathrm{SO}_{3}$ & 0.74 & 0.57 & 0.74 & 0.66 & 0.66 & 0.50 \\
\hline $\mathrm{ZrO}_{2}$ & 0.13 & 0.14 & 0.13 & 0.11 & 0.11 & 0.13 \\
\hline Sum & 100.00 & 100.00 & 100.00 & 100.00 & 100.00 & 100.00 \\
\hline
\end{tabular}

*: $\mathrm{B}_{2} \mathrm{O}_{3}$ and $\mathrm{Li}_{2} \mathrm{O}$ from DCP analysis

$\$$ : Reported as $\mathrm{Tl}_{2} \mathrm{O}_{3}$ by XRF and converted

NA: Not analyzed 
Table 5c. Target and XRF Analysis of Glass Compositions for Waste Batch 4006 (wt\%). $\mathrm{B}_{2} \mathrm{O}_{3}, \mathrm{Li}_{2} \mathrm{O}$ and $\mathrm{F}$ in XRF column are target values unless otherwise noted (continued).

\begin{tabular}{|c|c|c|c|c|c|c|}
\hline Sample ID & \multicolumn{2}{|c|}{ HWBi4006-7 } & \multicolumn{2}{|c|}{ HWBi4006-8 } & \multicolumn{2}{|c|}{ HWBi4006-9 } \\
\hline Waste & \multicolumn{2}{|c|}{45} & \multicolumn{2}{|c|}{40} & \multicolumn{2}{|c|}{35} \\
\hline Data Type & Target & XRF & Target & XRF & Target & XRF \\
\hline $\mathrm{Al}_{2} \mathrm{O}_{3}$ & 19.78 & 19.33 & 21.02 & 20.20 & 13.77 & 13.36 \\
\hline $\mathrm{B}_{2} \mathrm{O}_{3}$ & 18.23 & 18.23 & 19.21 & $19.23^{*}$ & 18.18 & 18.18 \\
\hline $\mathrm{BaO}$ & 0.00 & 0.00 & 0.00 & 0.00 & 0.00 & 0.00 \\
\hline $\mathrm{Bi}_{2} \mathrm{O}_{3}$ & 2.89 & 3.26 & 2.57 & 3.04 & 2.24 & 2.78 \\
\hline $\mathrm{Cl}$ & 0.00 & 0.02 & 0.00 & 0.04 & 0.00 & 0.03 \\
\hline $\mathrm{CaO}$ & 0.80 & 0.85 & 0.71 & 0.74 & 0.62 & 0.69 \\
\hline $\mathrm{Cr}_{2} \mathrm{O}_{3}$ & 0.69 & 0.60 & 0.61 & 0.55 & 0.53 & 0.55 \\
\hline $\mathbf{F}$ & 0.38 & NA & 0.34 & 0.34 & 0.30 & $\mathrm{NA}$ \\
\hline $\mathrm{Fe}_{2} \mathrm{O}_{3}$ & 2.94 & 3.01 & 2.62 & 2.75 & 2.29 & 2.50 \\
\hline $\mathrm{K}_{2} \mathrm{O}$ & 2.45 & 2.50 & 2.17 & 2.18 & 1.90 & 1.79 \\
\hline $\mathrm{La}_{2} \mathrm{O}_{3}$ & 0.82 & 1.10 & 0.73 & 1.07 & 0.64 & 0.84 \\
\hline $\mathrm{Li}_{2} \mathrm{O}$ & 0.00 & 0.00 & 0.00 & $0.00^{*}$ & 3.50 & 3.50 \\
\hline MgO & 0.35 & 0.27 & 0.31 & 0.23 & 0.27 & 0.21 \\
\hline MnO & 3.20 & 3.25 & 2.85 & 2.91 & 2.49 & 2.63 \\
\hline $\mathrm{Na}_{2} \mathrm{O}$ & 13.98 & 14.21 & 12.43 & 12.10 & 10.87 & 10.21 \\
\hline $\mathrm{NiO}$ & 2.01 & 2.16 & 1.79 & 1.92 & 1.57 & 1.89 \\
\hline $\mathrm{P}_{2} \mathrm{O}_{5}$ & 4.14 & 4.44 & 3.68 & 4.01 & 3.22 & 3.75 \\
\hline PbO & 0.23 & 0.27 & 0.21 & 0.24 & 0.18 & 0.23 \\
\hline $\mathrm{SiO}_{2}$ & 26.04 & 25.66 & 27.81 & 27.56 & 36.59 & 36.01 \\
\hline SrO & 0.14 & 0.14 & 0.12 & 0.13 & 0.11 & 0.12 \\
\hline $\mathrm{TiO}_{2}$ & 0.00 & 0.00 & 0.00 & 0.00 & 0.00 & 0.02 \\
\hline $\mathrm{Tl}_{2} \mathrm{O}^{\$}$ & 0.06 & 0.04 & 0.05 & 0.05 & 0.04 & 0.04 \\
\hline $\mathrm{SO}_{3}$ & 0.74 & 0.52 & 0.66 & 0.58 & 0.58 & 0.53 \\
\hline $\mathrm{ZrO}_{2}$ & 0.13 & 0.14 & 0.11 & 0.14 & 0.10 & 0.13 \\
\hline Sum & 100.00 & 100.00 & 100.00 & 100.00 & 100.00 & 100.00 \\
\hline
\end{tabular}

*: $\mathrm{B}_{2} \mathrm{O}_{3}$ and $\mathrm{Li}_{2} \mathrm{O}$ from DCP analysis

$\$$ : Reported as $\mathrm{Tl}_{2} \mathrm{O}_{3}$ by XRF and converted

NA: Not analyzed 
Table 5c. Target and XRF Analysis of Glass Compositions for Waste Batch 4006 (wt\%). $\mathrm{B}_{2} \mathrm{O}_{3}, \mathrm{Li}_{2} \mathrm{O}$ and $\mathrm{F}$ in XRF column are target values unless otherwise noted (continued).

\begin{tabular}{|c|c|c|}
\hline Sample ID & \multicolumn{2}{|c|}{ HWBi4006-10 } \\
\hline Waste & \multicolumn{2}{|c|}{35} \\
\hline Data Type & Target & XRF \\
\hline $\mathbf{A l}_{2} \mathbf{O}_{3}$ & 20.27 & 19.65 \\
\hline $\mathrm{B}_{2} \mathrm{O}_{3}$ & 19.18 & 19.18 \\
\hline $\mathrm{BaO}$ & 0.00 & 0.00 \\
\hline $\mathrm{Bi}_{2} \mathrm{O}_{3}$ & 2.24 & 2.75 \\
\hline $\mathrm{Cl}$ & 0.00 & 0.04 \\
\hline $\mathrm{CaO}$ & 0.62 & 0.67 \\
\hline $\mathrm{Cr}_{2} \mathrm{O}_{3}$ & 0.53 & 0.56 \\
\hline F & 0.30 & NA \\
\hline $\mathrm{Fe}_{2} \mathrm{O}_{3}$ & 2.29 & 2.53 \\
\hline $\mathbf{K}_{2} \mathbf{O}$ & 1.90 & 2.06 \\
\hline $\mathrm{La}_{2} \mathbf{O}_{3}$ & 0.64 & 0.96 \\
\hline $\mathbf{L i}_{2} \mathbf{O}$ & 2.00 & 2.00 \\
\hline MgO & 0.27 & 0.21 \\
\hline MnO & 2.49 & 2.55 \\
\hline $\mathrm{Na}_{2} \mathrm{O}$ & 10.87 & 10.55 \\
\hline $\mathrm{NiO}$ & 1.57 & 1.77 \\
\hline $\mathrm{P}_{2} \mathrm{O}_{5}$ & 3.22 & 3.64 \\
\hline PbO & 0.18 & 0.23 \\
\hline $\mathrm{SiO}_{2}$ & 30.59 & 29.85 \\
\hline SrO & 0.11 & 0.12 \\
\hline $\mathrm{TiO}_{2}$ & 0.00 & 0.02 \\
\hline $\mathrm{Tl}_{2} \mathrm{O}^{\$}$ & 0.04 & 0.04 \\
\hline $\mathrm{SO}_{3}$ & 0.58 & 0.50 \\
\hline $\mathrm{ZrO}_{2}$ & 0.10 & 0.12 \\
\hline Sum & 100.00 & 99.99 \\
\hline
\end{tabular}

\$: Reported as $\mathrm{Tl}_{2} \mathrm{O}_{3}$ by XRF and converted NA: Not analyzed 
Table 6a. Characterization of Glass Samples for Waste Batch 2394 (Sp=Spinel; Apt=Apatite).

\begin{tabular}{|c|c|c|c|c|}
\hline Glass ID & HWBi2394-1 & HWBi2394-2 & HWBi2394-3 & HWBi2394-4 \\
\hline Waste loading (wt\%) & 50 & 50 & 45 & 40 \\
\hline $\begin{array}{l}\text { Visual Inspection of Poured } \\
\text { Glass Specimen }\end{array}$ & Trace Crystallization & Vitreous & Vitreous & Vitreous \\
\hline Foaming During $\mathrm{CCC}$ & $\begin{array}{l}\text { Large vesicles near } \\
\text { bottom }\end{array}$ & None & None & None \\
\hline $\begin{array}{l}\text { Vol\% of Crystalline Phase at } \\
\qquad 950^{\circ} \mathrm{C}\end{array}$ & $1.1 \% \mathrm{Sp}$ & $1.81 \% \mathrm{Sp}$ & $0.77 \% \mathrm{Sp}$ & $1.22 \% \mathrm{Sp}$ \\
\hline $\begin{array}{l}\text { Vol\% of Crystalline Phase at } \\
\qquad 900^{\circ} \mathrm{C}\end{array}$ & $1.8 \%, \mathrm{Sp}+$ trace Apt & $1.97 \% \mathrm{Sp}$ & $1.16 \% \mathrm{Sp}$ & $1.33 \% \mathrm{Sp}$ \\
\hline $\begin{array}{c}\text { Vol\% of Crystalline Phase at } \\
\qquad 850^{\circ} \mathrm{C}\end{array}$ & $2.3 \% \mathrm{Sp}+$ trace Apt & $2.6 \% \mathrm{Sp}+$ trace Apt & $1.98 \% \mathrm{Sp}+$ trace Apt & $1.85 \% \mathrm{Sp}+$ trace Apt \\
\hline $\begin{array}{l}\text { Vol\% of Crystalline Phase at } \\
\qquad \mathbf{8 0 0}^{\circ} \mathrm{C}\end{array}$ & $2.7 \% \mathrm{Sp}+0.3 \% \mathrm{Apt}$ & $\begin{array}{c}3.5 \% \mathrm{Sp}+0.5 \% \mathrm{Apt} \\
+ \text { trace phosphate } \\
(?)\end{array}$ & $\begin{array}{c}2.32 \% \mathrm{Sp}+0.5 \% \\
\text { phosphate (?) }+0.2 \% \\
\mathrm{Apt}\end{array}$ & $\begin{array}{c}2.5 \% \mathrm{Sp}+1.1 \% \mathrm{Apt}+ \\
1.3 \% \text { phosphate }(?)\end{array}$ \\
\hline Viscosity (Poise) at $1150^{\circ} \mathrm{C}$ & - & - & 15.6 Poise & 25 Poise \\
\hline $\begin{array}{l}\text { Electrical Conductivity }(\mathrm{S} / \mathrm{cm}) \\
\text { at } 1150^{\circ} \mathrm{C}\end{array}$ & - & - & $0.38 \mathrm{~S} / \mathrm{cm}$ & $0.35 \mathrm{~S} / \mathrm{cm}$ \\
\hline 7 Day PCT-B (g/L) & - & - & 0.849 & 0.941 \\
\hline TCLP & - & - & PASS & PASS \\
\hline
\end{tabular}


Table 6b. Characterization of Glass Samples for Waste Batch 4098 (Sp=Spinel; Apt=Apatite).

\begin{tabular}{|c|c|c|c|c|c|c|}
\hline Glass ID & HWBi4098-1 & HWBi4098-2 & HWBi4098-3 & HWBi4098-4 & HWBi4098-5 & HWBi4098-6 \\
\hline Waste loading (wt \%) & 50 & 45 & 45 & 45 & 45 & 40 \\
\hline $\begin{array}{l}\text { Visual Inspection of Poured } \\
\text { Glass Specimen }\end{array}$ & $\begin{array}{c}\text { Trace } \\
\text { Crystallization }\end{array}$ & $\begin{array}{c}\text { Trace } \\
\text { Crystallization }\end{array}$ & $\begin{array}{c}\text { Trace } \\
\text { Crystallization }\end{array}$ & $\begin{array}{c}\text { Trace } \\
\text { Crystallization }\end{array}$ & $\begin{array}{c}\text { Trace } \\
\text { Crystallization }\end{array}$ & Vitreous \\
\hline Foaming During $\mathrm{CCC}$ & $\begin{array}{l}\text { Large vesicles near } \\
\text { bottom } / \text { side }\end{array}$ & $\begin{array}{l}\text { Few vesicles on } \\
\text { bottom } / \text { side }\end{array}$ & None & $\begin{array}{l}\text { One vesicle on } \\
\text { bottom }\end{array}$ & $\begin{array}{l}\text { Few vesicles on } \\
\text { bottom }\end{array}$ & $\begin{array}{l}\text { One large vesicle on } \\
\text { bottom }\end{array}$ \\
\hline $\begin{array}{l}\text { Vol\% of Crystalline Phase at } \\
\qquad 950^{\circ} \mathrm{C}\end{array}$ & $0.8 \% \mathrm{Sp}$ & $\begin{array}{c}2.33 \% \mathrm{Apt}+ \\
0.66 \% \mathrm{Sp}\end{array}$ & $\begin{array}{l}3.95 \% \mathrm{Apt}+ \\
0.85 \mathrm{Sp}\end{array}$ & $\begin{array}{c}0.76 \% \mathrm{Sp}+0.08 \% \\
\mathrm{Apt}\end{array}$ & $\begin{array}{c}0.48 \% \mathrm{Apt}+0.44 \% \\
\mathrm{Sp}+0.35 \% \mathrm{Na}-\mathrm{Ca} \\
\text { phosphate }\end{array}$ & $0.73 \% \mathrm{Sp}$ with $\mathrm{Al}$ \\
\hline $\begin{array}{l}\text { Vol\% of Crystalline Phase at } \\
\qquad 900^{\circ} \mathrm{C}\end{array}$ & $\begin{array}{l}1.3 \% \mathrm{Apt}+0.9 \% \\
\mathrm{Sp}\end{array}$ & $\begin{array}{c}3.97 \% \mathrm{Apt}+ \\
0.94 \% \mathrm{Sp}\end{array}$ & $\begin{array}{c}6.2 \% \mathrm{Apt}+1.2 \% \\
\mathrm{Sp}\end{array}$ & $\begin{array}{c}0.98 \% \mathrm{Apt}+0.66 \% \\
\mathrm{Sp}+\text { trace La- } \\
\text { phosphate }\end{array}$ & $\begin{array}{c}1.5 \% \mathrm{Na}-\mathrm{Ca} \\
\text { phosphate }+1 \% \\
\mathrm{Apt}+0.5 \% \mathrm{Sp}\end{array}$ & $\begin{array}{l}0.62 \% \mathrm{Sp} \text { with } \mathrm{Al}+ \\
0.41 \% \mathrm{Apt}+\text { trace La- } \\
\text { phosphate }\end{array}$ \\
\hline $\begin{array}{l}\text { Vol\% of Crystalline Phase at } \\
\qquad 850^{\circ} \mathrm{C}\end{array}$ & $\begin{array}{c}1.5 \% \mathrm{Apt}+1.1 \% \\
\mathrm{Sp}\end{array}$ & $\begin{array}{c}4.9 \% \mathrm{Apt}+1 \% \\
\mathrm{Sp}\end{array}$ & $\begin{array}{l}7.2 \% \mathrm{Apt}+1.4 \\
\mathrm{Sp}\end{array}$ & $\begin{array}{c}1.2 \% \mathrm{Sp}+0.8 \% \mathrm{Apt} \\
+0.2 \% \mathrm{Na}-\mathrm{Ca} \\
\text { phosphate }\end{array}$ & $\begin{array}{c}1.61 \% \mathrm{Apt}+1.6 \% \\
\mathrm{Na}-\mathrm{Ca} \text { phosphate }+ \\
0.58 \% \mathrm{Sp}\end{array}$ & $\begin{array}{c}1.1 \% \mathrm{Apt}+0.78 \% \mathrm{Sp} \\
\text { with } \mathrm{Al}+\text { trace La- } \\
\text { phosphate + trace Na- } \\
\text { Ca Phosphate }\end{array}$ \\
\hline $\begin{array}{l}\text { Vol\% of Crystalline Phase at } \\
\qquad 800^{\circ} \mathrm{C}\end{array}$ & $\begin{array}{c}0.6 \% \mathrm{Sp}+0.4 \% \\
\mathrm{Apt}+0.1 \% \mathrm{Na}-\mathrm{Ca} \\
\text { Phosphate }\end{array}$ & $\begin{array}{c}6 \% \mathrm{Apt}+1.2 \% \\
\mathrm{Sp}\end{array}$ & $\begin{array}{l}8.8 \% \mathrm{Apt}+1 \% \\
\mathrm{Sp}\end{array}$ & $\begin{array}{c}2.1 \% \mathrm{Apt}+0.9 \% \mathrm{Sp} \\
+0.5 \% \mathrm{Na}-\mathrm{Ca} \\
\text { phosphate }\end{array}$ & $\begin{array}{c}2.26 \% \mathrm{Apt}+2 \% \\
\mathrm{Na}-\mathrm{Ca} \text { phosphate }+ \\
0.66 \% \mathrm{Sp}\end{array}$ & $\begin{array}{c}2.1 \% \mathrm{Apt}+1 \% \mathrm{Sp} \\
\text { with } \mathrm{Al}+0.8 \% \\
\text { phosphate }\end{array}$ \\
\hline Viscosity (Poise) at $1150^{\circ} \mathrm{C}$ & - & - & - & - & - & - \\
\hline $\begin{array}{l}\text { Electrical Conductivity } \\
(\mathrm{S} / \mathrm{cm}) \text { at } 1150^{\circ} \mathrm{C}\end{array}$ & - & - & - & - & - & - \\
\hline 7 Day PCT-B (g/L) & - & - & - & - & - & 0.657 \\
\hline TCLP & - & - & - & - & - & PASS \\
\hline
\end{tabular}

- Empty data field. 
Table 6b. Characterization of Glass Samples for Waste Batch 4098 (Sp=Spinel; Apt=Apatite) (continued).

\begin{tabular}{|c|c|c|c|c|}
\hline Glass ID & HWBi4098-7 & HWBi4098-8 & HWBi4098-9 & HWBi4098-10 \\
\hline $\begin{array}{c}\text { Waste loading } \\
(w t \%)\end{array}$ & 45 & 40 & 40 & 35 \\
\hline $\begin{array}{l}\text { Visual Inspection of } \\
\text { Poured Glass } \\
\text { Specimen }\end{array}$ & Vitreous & Trace Crystallization & Trace Crystallization & Vitreous \\
\hline $\begin{array}{c}\text { Foaming During } \\
\text { CCC }\end{array}$ & None & $\begin{array}{l}\text { One large vesicle on } \\
\text { bottom }\end{array}$ & None & None \\
\hline $\begin{array}{c}\text { Vol\% of Crystalline } \\
\text { Phase at } 950^{\circ} \mathrm{C}\end{array}$ & $0.78 \%$ Sp with $\mathrm{Al}$ & $0.66 \% \mathrm{Sp}$ with $\mathrm{Al}$ & $\begin{array}{l}1.76 \% \text { Sp with } \mathrm{Al}+ \\
0.14 \% \text { La-phosphate }\end{array}$ & $0.64 \% \mathrm{Sp}$ with $\mathrm{Al}$ \\
\hline $\begin{array}{c}\text { Vol\% of Crystalline } \\
\text { Phase at } 900^{\circ} \mathrm{C}\end{array}$ & $0.68 \% \mathrm{Sp}$ with $\mathrm{Al}$ & $1.02 \% \mathrm{Sp}$ with $\mathrm{Al}$ & $\begin{array}{l}2.31 \% \text { Sp with } \mathrm{Al}+ \\
0.37 \% \text { La-phosphate }\end{array}$ & $0.81 \% \mathrm{Sp}$ with $\mathrm{Al}$ \\
\hline $\begin{array}{l}\text { Vol\% of Crystalline } \\
\text { Phase at } 850^{\circ} \mathrm{C}\end{array}$ & $\begin{array}{c}1.08 \% \text { Sp with } \mathrm{Al}+0.27 \% \\
\mathrm{Apt}\end{array}$ & $\begin{array}{c}1.05 \% \mathrm{Sp} \text { with } \mathrm{Al}+ \\
\text { trace Apt }+ \text { trace La- } \\
\text { phosphate }\end{array}$ & $\begin{array}{c}2.4 \% \text { Sp with } \mathrm{Al}+0.3 \% \\
\text { La-phosphate }\end{array}$ & $\begin{array}{c}1 \% \text { Sp with } \mathrm{Al}+\text { trace } \\
\mathrm{Apt}+\text { trace La-phosphate }\end{array}$ \\
\hline $\begin{array}{l}\text { Vol\% of Crystalline } \\
\text { Phase at } 800^{\circ} \mathrm{C}\end{array}$ & $\begin{array}{c}1.53 \% \mathrm{Apt}+1.46 \% \\
\text { phosphate }(?)+1.36 \% \mathrm{Sp} \\
\text { with } \mathrm{Al}+\text { trace La- } \\
\text { phosphate }\end{array}$ & $\begin{array}{l}1.4 \% \text { phosphate }(?)+ \\
1.16 \% \mathrm{Apt}+1.14 \% \mathrm{Sp} \\
+ \text { trace La-phosphate }\end{array}$ & $\begin{array}{c}1.02 \% \mathrm{Sp}+0.96 \% \mathrm{Apt}+ \\
0.26 \% \text { La-phosphate }+ \\
0.16 \% \text { phosphate }(?)\end{array}$ & $\begin{array}{c}1.6 \% \mathrm{Na}-\mathrm{Ca} \text { phosphate }+ \\
1.3 \% \mathrm{Apt}+1 \% \mathrm{Sp}+ \\
\text { trace La-phosphate }\end{array}$ \\
\hline $\begin{array}{c}\text { Viscosity (Poise) at } \\
1150^{\circ} \mathrm{C} \\
\end{array}$ & 25.6 Poise & - & - & - \\
\hline $\begin{array}{c}\text { Electrical } \\
\text { Conductivity }(\mathrm{S} / \mathrm{cm}) \\
\text { at } 1150^{\circ} \mathrm{C} \\
\end{array}$ & $0.43 \mathrm{~S} / \mathrm{cm}$ & - & - & - \\
\hline 7 Day PCT-B (g/L) & 1.801 & - & - & - \\
\hline TCLP & PASS & - & - & - \\
\hline
\end{tabular}

- Empty data field. 
Table 6c. Characterization of Glass Samples for Waste Batch 4006 (Sp=Spinel; Apt=Apatite).

\begin{tabular}{|c|c|c|c|c|c|c|c|}
\hline Glass ID & HWBi4006-1 & HWBi4006-2 & HWBi4006-3 & HWBi4006-4 & HWBi4006-5 & HWBi4006-6 & HWBi4006-7 \\
\hline Waste loading (wt\%) & 50 & 45 & 45 & 45 & 45 & 40 & 45 \\
\hline $\begin{array}{l}\text { Visual Inspection of Poured } \\
\text { Glass Specimen }\end{array}$ & $\begin{array}{c}\text { Trace } \\
\text { Crystallization }\end{array}$ & $\begin{array}{c}\text { Trace } \\
\text { Crystallization }\end{array}$ & $\begin{array}{c}\text { Trace } \\
\text { Crystallization }\end{array}$ & Vitreous & Vitreous & Vitreous & $\begin{array}{c}\text { Trace } \\
\text { Crystallization }\end{array}$ \\
\hline Foaming During CCC & $\begin{array}{l}\text { Few vesicles near } \\
\text { bottom }\end{array}$ & $\begin{array}{l}\text { One vesicle near } \\
\text { bottom }\end{array}$ & None & None & None & None & None \\
\hline $\begin{array}{l}\text { Vol\% of Crystalline Phase at } \\
\qquad 950^{\circ} \mathrm{C}\end{array}$ & $\begin{array}{l}2.6 \% \mathrm{Sp}+0.3 \% \\
\mathrm{Ca}-\mathrm{Na} \text { phosphate }\end{array}$ & $1.11 \% \mathrm{Sp}$ & $\begin{array}{l}2.2 \% \mathrm{Sp}+0.9 \% \\
\text { Na-Ca phosphate }\end{array}$ & $\begin{array}{l}0.69 \% \mathrm{Sp}+0.4 \% \\
\text { Na-Ca phosphate }\end{array}$ & $\begin{array}{l}0.29 \% \mathrm{Sp}+0.3 \% \\
\text { Na-Ca phosphate }\end{array}$ & $1.10 \% \mathrm{Sp}$ & $\begin{array}{c}2.93 \% \text { Sp with } \mathrm{Al}+ \\
0.32 \% \text { La- } \\
\text { phosphate }\end{array}$ \\
\hline $\begin{array}{l}\text { Vol\% of Crystalline Phase at } \\
\qquad 900^{\circ} \mathrm{C}\end{array}$ & $\begin{array}{c}3 \% \mathrm{Ca}-\mathrm{Na} \\
\text { phosphate }+2.1 \% \\
\mathrm{Sp}\end{array}$ & $1.81 \% \mathrm{Sp}$ & $\begin{array}{c}2.2 \% \mathrm{Sp}+1 \% \mathrm{Na}- \\
\text { Ca phosphate }+ \\
\text { trace La-phosphate }\end{array}$ & $\begin{array}{l}1 \% \mathrm{Sp}+0.8 \% \mathrm{Na}- \\
\text { Ca phosphate }\end{array}$ & $\begin{array}{c}1.2 \% \mathrm{Na}-\mathrm{Ca} \\
\text { phosphate }+0.5 \% \\
\mathrm{Sp}\end{array}$ & $\begin{array}{l}1.44 \% \mathrm{Sp}+\text { trace } \\
\text { La-phosphate }\end{array}$ & $\begin{array}{c}2.9 \% \text { Sp with } \mathrm{Al}+ \\
0.4 \% \text { La-phosphate } \\
+0.26 \% \mathrm{Na}-\mathrm{Ca} \\
\text { phosphate }\end{array}$ \\
\hline $\begin{array}{l}\text { Vol\% of Crystalline Phase at } \\
\qquad 850^{\circ} \mathrm{C}\end{array}$ & $\begin{array}{c}4.4 \% \mathrm{Ca}-\mathrm{Na} \\
\text { phosphate }+2.2 \% \\
\mathrm{Sp}\end{array}$ & $\begin{array}{l}2.2 \% \mathrm{Sp}+1.1 \mathrm{Na}- \\
\quad \text { Ca Phosphate }\end{array}$ & $\begin{array}{c}2.4 \% \mathrm{Na}-\mathrm{Ca} \\
\text { Phosphate }+2.4 \% \\
\text { Sp }\end{array}$ & $\begin{array}{c}3.1 \% \text { phosphate }+ \\
1 \% \mathrm{Sp}\end{array}$ & $\begin{array}{c}1.5 \% \mathrm{Na}-\mathrm{Ca} \\
\text { phosphate }+0.49 \% \\
\mathrm{Sp}\end{array}$ & $\begin{array}{l}1.9 \% \mathrm{Sp}+0.3 \% \\
\text { Na-Ca Phosphate }+ \\
\text { trace La-Phosphate }\end{array}$ & $\begin{array}{c}2.6 \% \mathrm{Sp} \text { with } \mathrm{Al}+ \\
0.93 \% \mathrm{Na}-\mathrm{Ca} \\
\text { phosphate }+0.06 \% \\
\text { La-P } \\
\end{array}$ \\
\hline $\begin{array}{l}\text { Vol\% of Crystalline Phase at } \\
\qquad 800^{\circ} \mathrm{C}\end{array}$ & $\begin{array}{l}2 \% \mathrm{Sp}+1 \% \mathrm{Na}-\mathrm{Ca} \\
\text { phosphate }\end{array}$ & $\begin{array}{c}3.3 \% \mathrm{Na}-\mathrm{Ca} \\
\text { phosphate }+1.7 \% \\
\mathrm{Sp}\end{array}$ & $\begin{array}{c}2.3 \% \mathrm{Na}-\mathrm{Ca} \\
\text { phosphate }+2.1 \% \\
\mathrm{Sp}\end{array}$ & $\begin{array}{c}2.2 \% \text { phosphate }+ \\
1 \% \mathrm{Sp}\end{array}$ & $\begin{array}{c}3.5 \% \mathrm{Na}-\mathrm{Ca} \\
\text { phosphate }+0.1 \% \\
\mathrm{Sp}\end{array}$ & $\begin{array}{c}2.3 \% \mathrm{Sp}+1.2 \mathrm{Na}- \\
\text { Ca phosphate }+ \\
\text { trace La-phosphate }\end{array}$ & $\begin{array}{c}3 \% \mathrm{Sp} \text { with } \mathrm{Al}+ \\
1.3 \% \mathrm{Na}-\mathrm{Ca} \\
\text { phosphate }+0.1 \% \\
\text { La-phosphate }\end{array}$ \\
\hline Viscosity (Poise) at $1150^{\circ} \mathrm{C}$ & - & - & - & 62.5 Poise & 155.8 Poise & - & - \\
\hline $\begin{array}{l}\text { Electrical Conductivity }(\mathrm{S} / \mathrm{cm}) \text { at } \\
\qquad \mathbf{1 1 5 0}^{\circ} \mathrm{C}\end{array}$ & - & - & - & $0.27 \mathrm{~S} / \mathrm{cm}$ & $0.26 \mathrm{~S} / \mathrm{cm}$ & - & - \\
\hline 7 Day PCT-B (g/L) & - & - & - & 3.789 & 0.374 & 4.487 & - \\
\hline TCLP & - & - & - & PASS & PASS & PASS & - \\
\hline
\end{tabular}

- Empty data field. 
Table 6c. Characterization of Glass Samples for Waste Batch 4006 (Sp=Spinel; Apt=Apatite) (continued).

\begin{tabular}{|c|c|c|c|}
\hline Glass ID & HWBi4006-8 & HWBi4006-9 & HWBi4006-10 \\
\hline Waste loading (wt\%) & 40 & 35 & 35 \\
\hline $\begin{array}{l}\text { Visual Inspection of Poured } \\
\text { Glass Specimen }\end{array}$ & $\begin{array}{c}\text { Trace } \\
\text { Crystallization }\end{array}$ & Vitreous & Vitreous \\
\hline Foaming During CCC & None & None & None \\
\hline $\begin{array}{l}\text { Vol\% of Crystalline Phase at } \\
\qquad 950^{\circ} \mathrm{C}\end{array}$ & $\begin{array}{l}2.41 \% \text { Sp with } \mathrm{Al} \\
+0.35 \% \text { La- } \\
\text { phosphate }\end{array}$ & $0.73 \% \mathrm{Sp}$ with $\mathrm{Al}$ & $\begin{array}{c}0.3 \% \mathrm{Na}-\mathrm{Ca} \text { Phosphate }+ \\
0.1 \% \mathrm{Sp}\end{array}$ \\
\hline $\begin{array}{l}\text { Vol\% of Crystalline Phase at } \\
\qquad 900^{\circ} \mathrm{C}\end{array}$ & $\begin{array}{c}2.7 \% \text { Sp with } \mathrm{Al} \\
+0.5 \% \text { La- } \\
\text { phosphate }+0.3 \% \\
\text { Apt }\end{array}$ & $1.21 \% \mathrm{Sp}$ with $\mathrm{Al}$ & $\begin{array}{l}0.5 \% \text { Na-Ca phosphate }+ \\
0.23 \% \mathrm{Sp}\end{array}$ \\
\hline $\begin{array}{l}\text { Vol\% of Crystalline Phase at } \\
\qquad \mathbf{8 5 0}^{\circ} \mathrm{C}\end{array}$ & $\begin{array}{l}\text { 3\% Sp with } \mathrm{Al}+ \\
0.3 \text { La-phosphate } \\
+0.3 \% \mathrm{Apt}\end{array}$ & $\begin{array}{l}1.25 \% \text { Sp with } \mathrm{Al} \\
\text { + trace La- } \\
\text { Phosphate }\end{array}$ & $\begin{array}{c}1.82 \% \mathrm{Na}-\mathrm{Ca} \text { phosphate }+ \\
0.88 \% \mathrm{Apt}+0.47 \% \mathrm{Sp}\end{array}$ \\
\hline $\begin{array}{l}\text { Vol\% of Crystalline Phase at } \\
\qquad 800^{\circ} \mathrm{C}\end{array}$ & $\begin{array}{c}2.73 \% \mathrm{Sp} \text { with } \mathrm{Al} \\
+0.33 \% \mathrm{Apt}+ \\
0.18 \% \mathrm{La}- \\
\text { phosphate }\end{array}$ & $\begin{array}{c}1.89 \% \mathrm{Sp} \text { with } \mathrm{Al} \\
+1.1 \% \text { phosphate } \\
(?)+\text { trace La-P }\end{array}$ & $\begin{array}{c}3.4 \% \mathrm{Na}-\mathrm{Ca} \text { phosphate }+ \\
2.27 \% \mathrm{Apt}+0.46 \% \mathrm{Sp} \text { with } \\
\mathrm{Al}+\text { trace La-phosphate }\end{array}$ \\
\hline Viscosity (Poise) at $1150^{\circ} \mathrm{C}$ & - & - & - \\
\hline $\begin{array}{l}\text { Electrical Conductivity }(\mathrm{S} / \mathrm{cm}) \\
\text { at } 1150^{\circ} \mathrm{C}\end{array}$ & - & - & - \\
\hline 7 Day PCT-B (g/L) & 3.327 & - & - \\
\hline TCLP & PASS & - & - \\
\hline
\end{tabular}

- Empty data field. 
Table 7. Viscosity and Electrical Conductivity of Selected Bi-P Glass Melts.

\begin{tabular}{|c|c|c|c|c|c|c|c|c|c|c|}
\hline \multirow[b]{2}{*}{$\begin{array}{c}\text { Temperature } \\
\left({ }^{\circ} \mathrm{C}\right)\end{array}$} & \multicolumn{2}{|c|}{ HWBi4006-4 } & \multicolumn{2}{|c|}{ HWBi4006-5 } & \multicolumn{2}{|c|}{ HWBi4098-7 } & \multicolumn{2}{|c|}{ HWBi2394-3 } & \multicolumn{2}{|c|}{ HWBi2394-4 } \\
\hline & $\begin{array}{l}\text { Viscosity } \\
\text { (Poise) }\end{array}$ & $\begin{array}{l}\text { Conductivity } \\
(\mathrm{S} / \mathrm{cm})\end{array}$ & $\begin{array}{l}\text { Viscosity } \\
\text { (Poise) }\end{array}$ & $\begin{array}{l}\text { Conductivity } \\
(\mathrm{S} / \mathrm{cm})\end{array}$ & $\begin{array}{l}\text { Viscosity } \\
\text { (Poise) }\end{array}$ & $\begin{array}{l}\text { Conductivity } \\
(\mathrm{S} / \mathrm{cm})\end{array}$ & $\begin{array}{l}\text { Viscosity } \\
\text { (Poise) }\end{array}$ & $\begin{array}{c}\text { Conductivity } \\
(\mathrm{S} / \mathrm{cm})\end{array}$ & $\begin{array}{l}\text { Viscosity } \\
\text { (Poise) }\end{array}$ & $\begin{array}{l}\text { Conductivity } \\
(\mathrm{S} / \mathrm{cm})\end{array}$ \\
\hline 1250 & 28.24 & 0.35 & 64.62 & 0.36 & 12.63 & 0.58 & 7.86 & 0.50 & 12.80 & 0.45 \\
\hline 1150 & 62.49 & 0.27 & 155.82 & 0.26 & 25.64 & 0.43 & 15.57 & 0.38 & 25.00 & 0.35 \\
\hline 1050 & 174.81 & 0.19 & 473.62 & 0.18 & 62.50 & 0.31 & 36.77 & 0.27 & 59.47 & 0.25 \\
\hline 950 & 698.55 & 0.11 & 2016.28 & 0.12 & 198.38 & 0.21 & 111.80 & 0.17 & $190.68 *$ & 0.15 \\
\hline
\end{tabular}

*: Extrapolated from three data points above due to non-Newtonian behavior at $956^{\circ} \mathrm{C}$ in actual measurement 
Table 8. Normalized 7-Day PCT Element Releases for Selected Bi-P HLW Glasses.

\begin{tabular}{|c|c|c|c|}
\hline Glass ID & $\mathbf{B}(\mathbf{g} / \mathbf{L})$ & $\mathbf{L i}(\mathbf{g} / \mathbf{L})$ & $\mathbf{N a}(\mathbf{g} / \mathbf{L})$ \\
\hline DWPF-EA & 16.7 & 9.6 & 13.3 \\
\hline HWBi4006-4 & 3.789 & - & 2.363 \\
\hline HWBi4006-5 & $0 . .374$ & - & 0.461 \\
\hline HWBi4006-6 & 4.487 & 2.931 & 2.420 \\
\hline HWBi4006-8 & 3.327 & - & 1.974 \\
\hline HWBi4098-6 & 0.657 & 0.800 & 0.286 \\
\hline HWBi4098-7 & 1.801 & 1.340 & 0.974 \\
\hline HWBi2394-3 & 0.849 & 0.806 & 0.463 \\
\hline HWBi2394-4 & 0.941 & 0.904 & 0.394 \\
\hline
\end{tabular}


Table 9. TCLP Element Releases from Selected Bi-P HLW Glasses.

\begin{tabular}{|c|c|c|c|c|}
\hline Glass ID & Ba (ppm) & Cr (ppm) & Ni (ppm) & Pb (ppm) \\
\hline Delisting Limit & 100 & 4.95 & 22.6 & 5 \\
\hline HWBi4006-4 & - & 0.09 & 0.66 & $<0.1$ \\
\hline HWBi4006-5 & - & 0.09 & 0.34 & $<0.1$ \\
\hline HWBi4006-6 & - & 0.04 & 0.23 & $<0.1$ \\
\hline HWBi4006-8 & - & $<0.01$ & 0.17 & $<0.1$ \\
\hline HWBi4098-6 & - & 0.02 & 0.10 & $<0.1$ \\
\hline HWBi4098-7 & - & 0.03 & 0.13 & 0.13 \\
\hline HWBi2394-3 & - & 0.03 & 0.08 & $<0.1$ \\
\hline HWBi2394-3r & 0.02 & 0.03 & 0.07 & $<0.1$ \\
\hline HWBi2394-4 & - & 0.02 & 0.05 & $<0.1$ \\
\hline
\end{tabular}

- Empty data field. 
The Catholic Univer sity of America Vitreous State Laboratory
Development of High Waste Loading HLW Glasses for High Bismuth Phosphate Wastes Final Report, VSL-12R2550-1, Rev. 0

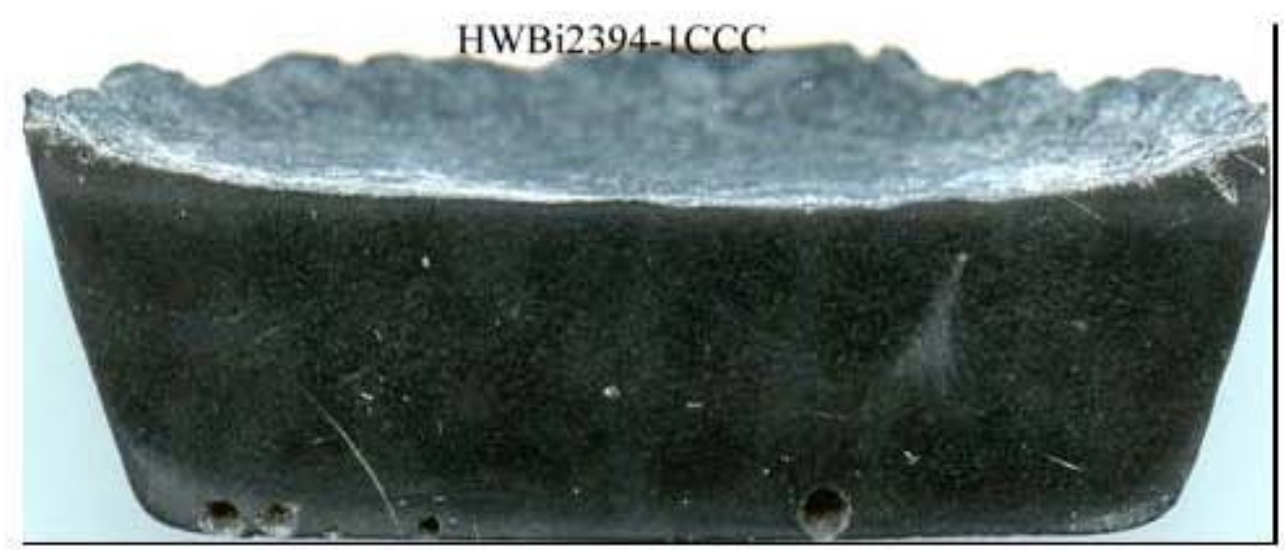

HWBi-2394-1CCC

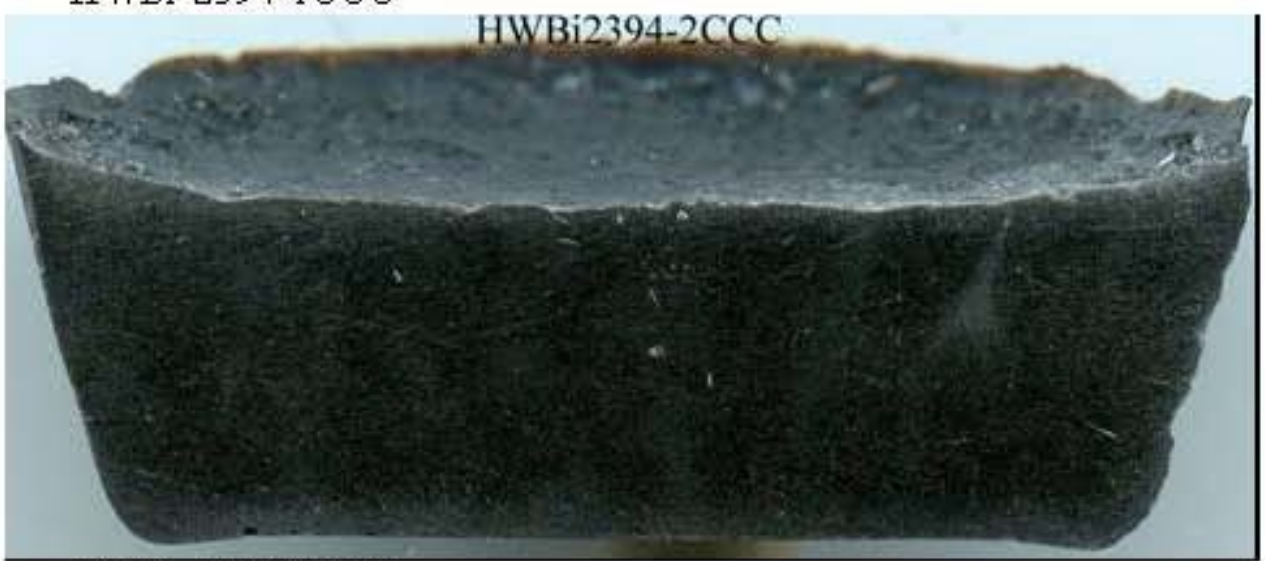

HWBi-2394-2CCC

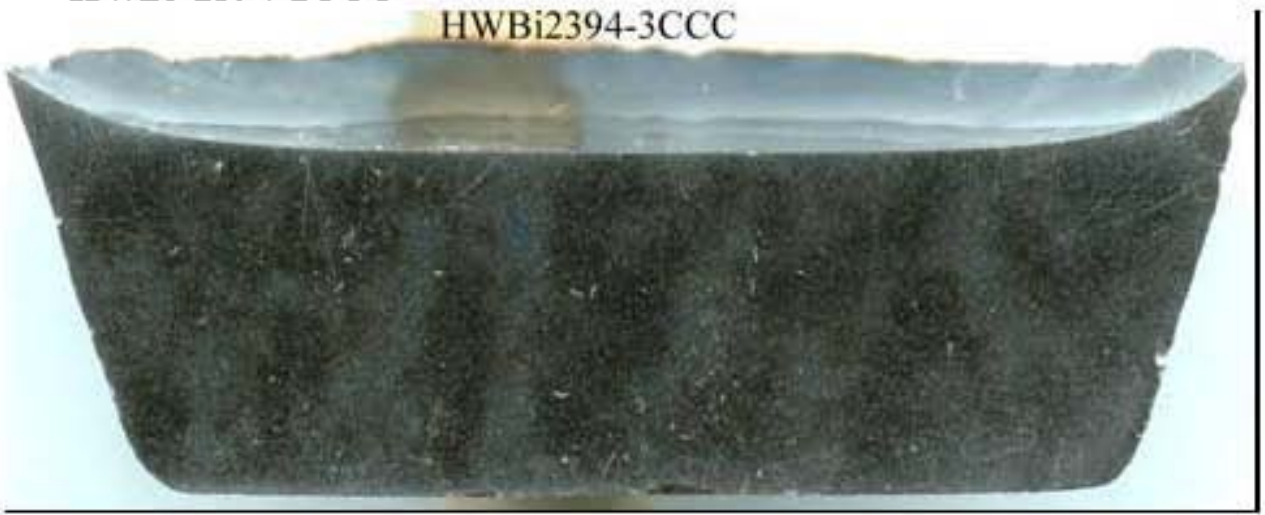

HWBi-2394-3CCC

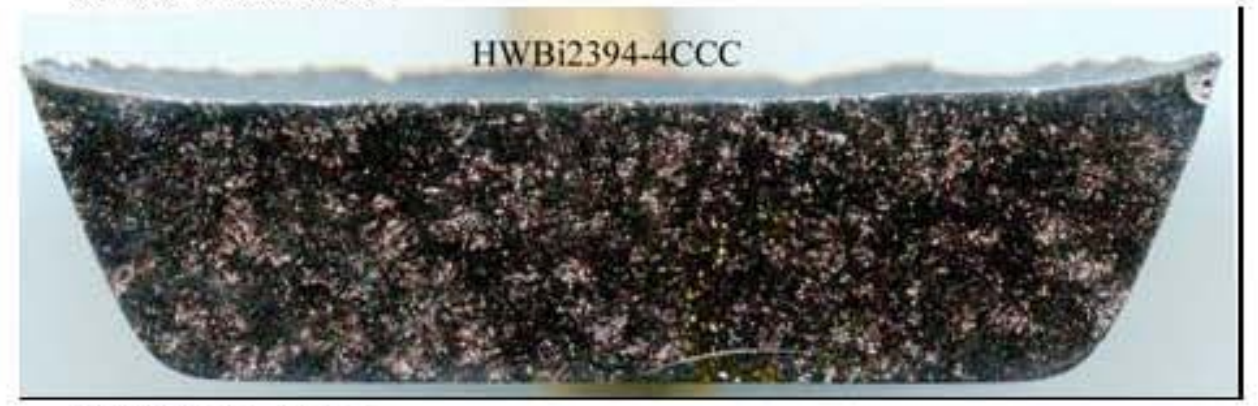

HWBi23944CCC

Figure 1. Cross sections of glass CCC samples of Waste Batch 2394. 


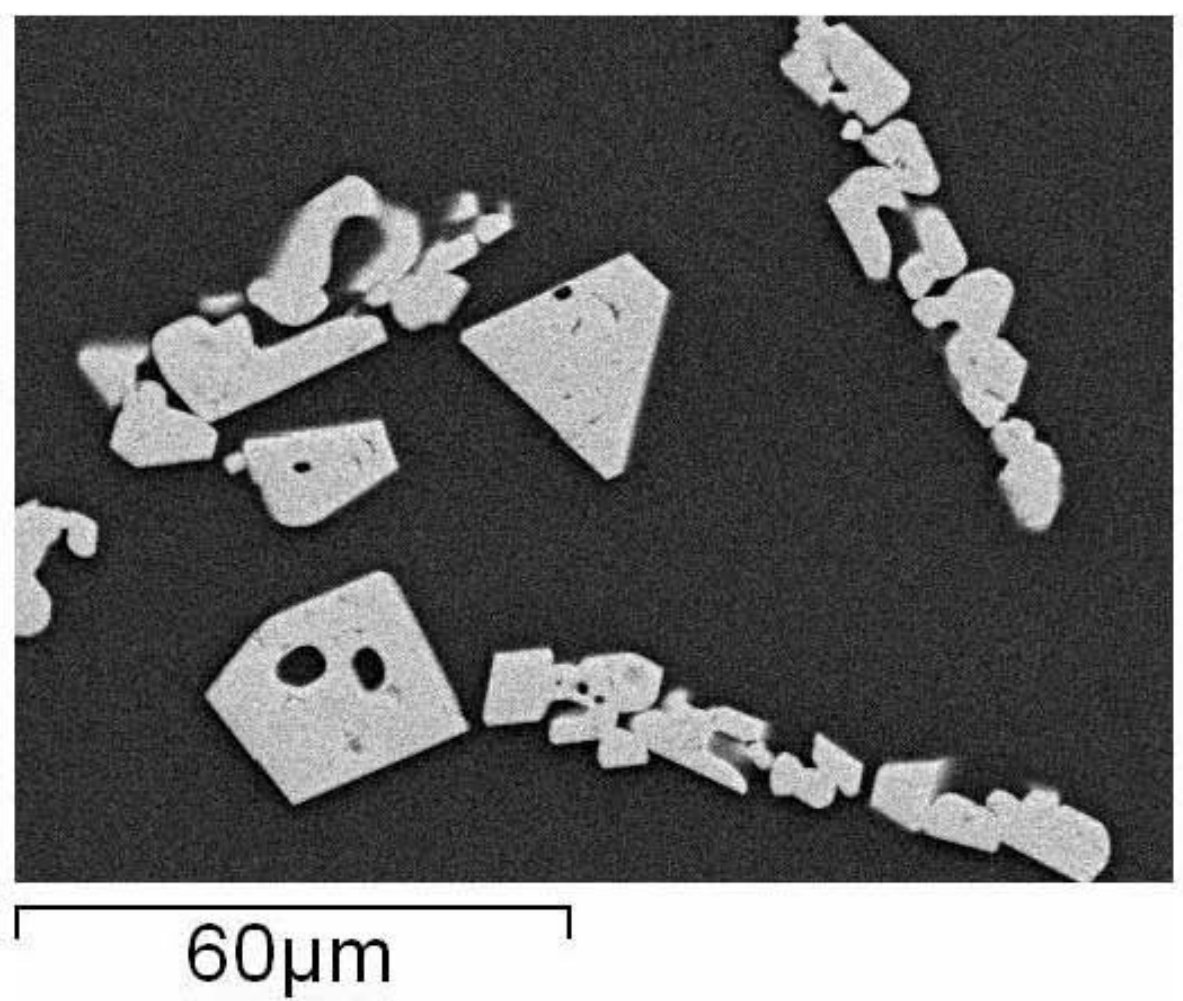

Figure 2a. SEM image of $\mathrm{HLWBi2394}-3$ heat treated at $950^{\circ} \mathrm{C}$ ( $\mathrm{Fe}-\mathrm{Cr}$-Ni spinel with $\mathrm{Mn}$ ).
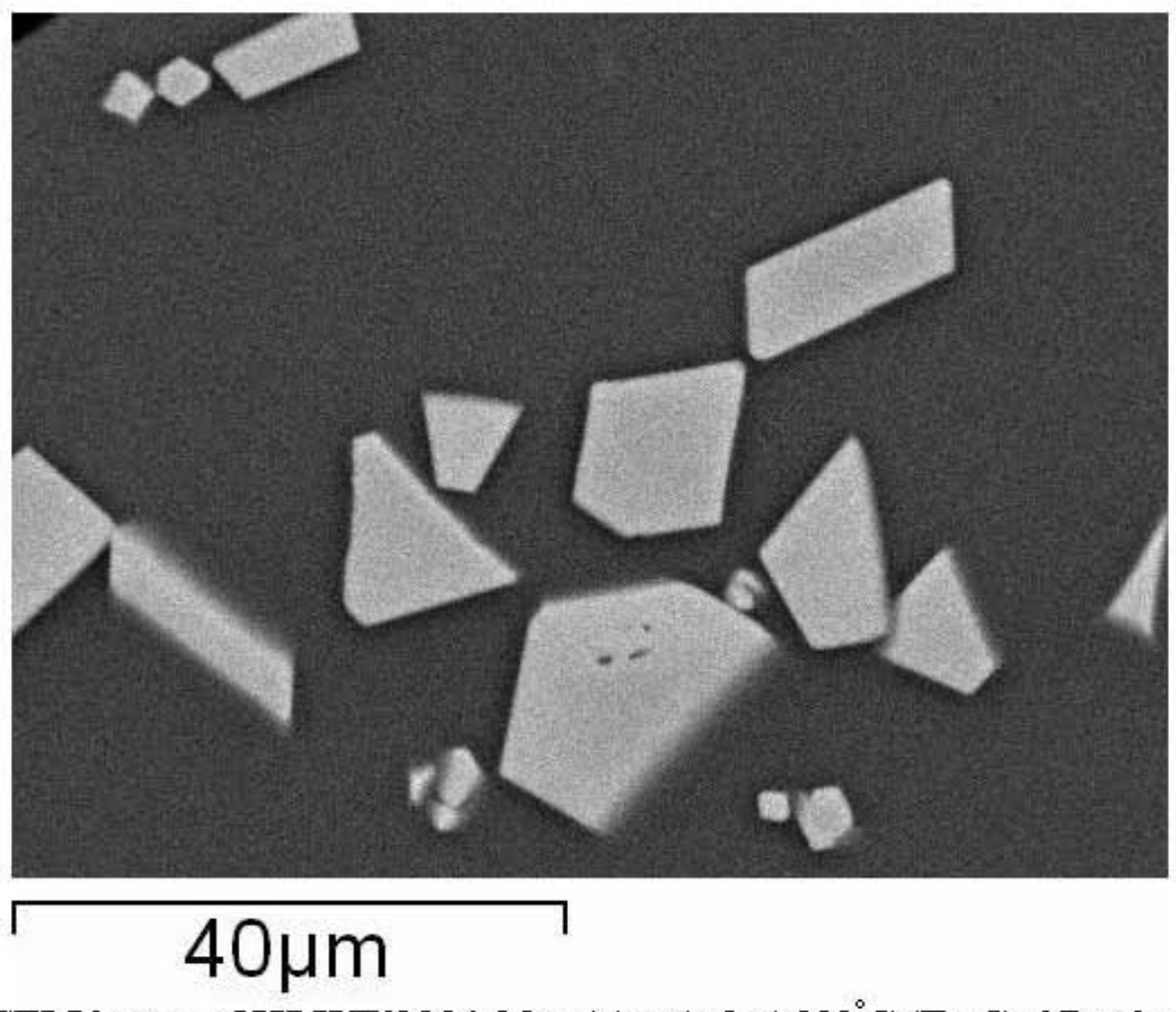

Figure 2b. SEM image of $\mathrm{HLWBi} 2394-3$ heat treated at $900^{\circ} \mathrm{C}$ ( $\mathrm{Fe}-\mathrm{Cr}$-Ni spinel with $\mathrm{Mn}$ ). 


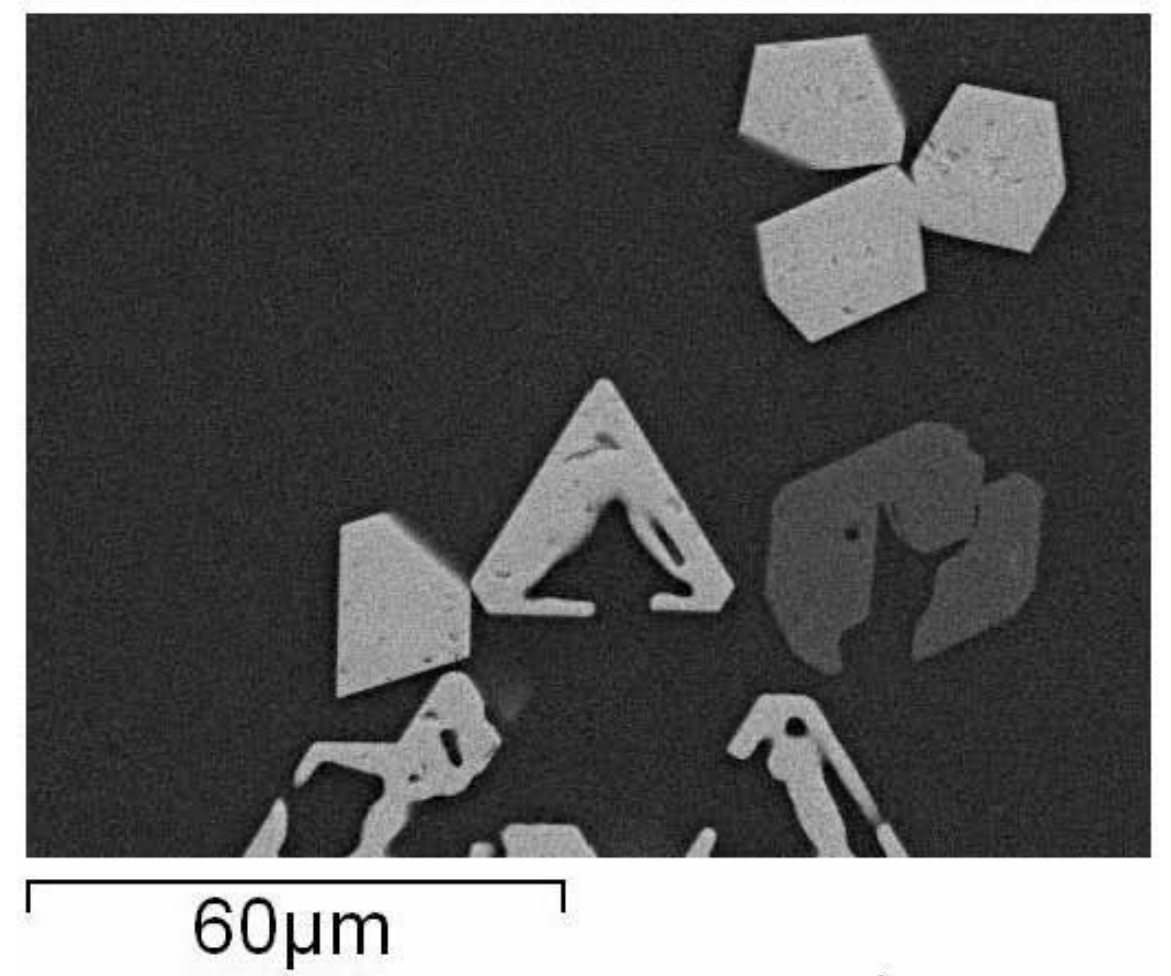

Figure 2c. SEM image of $\mathrm{HLWBi} 23943$ heat treated at $850^{\circ} \mathrm{C}$ (bright phase: $\mathrm{Fe}-\mathrm{Cr}$-Ni spinel with Mn; grey phase: Apatite).
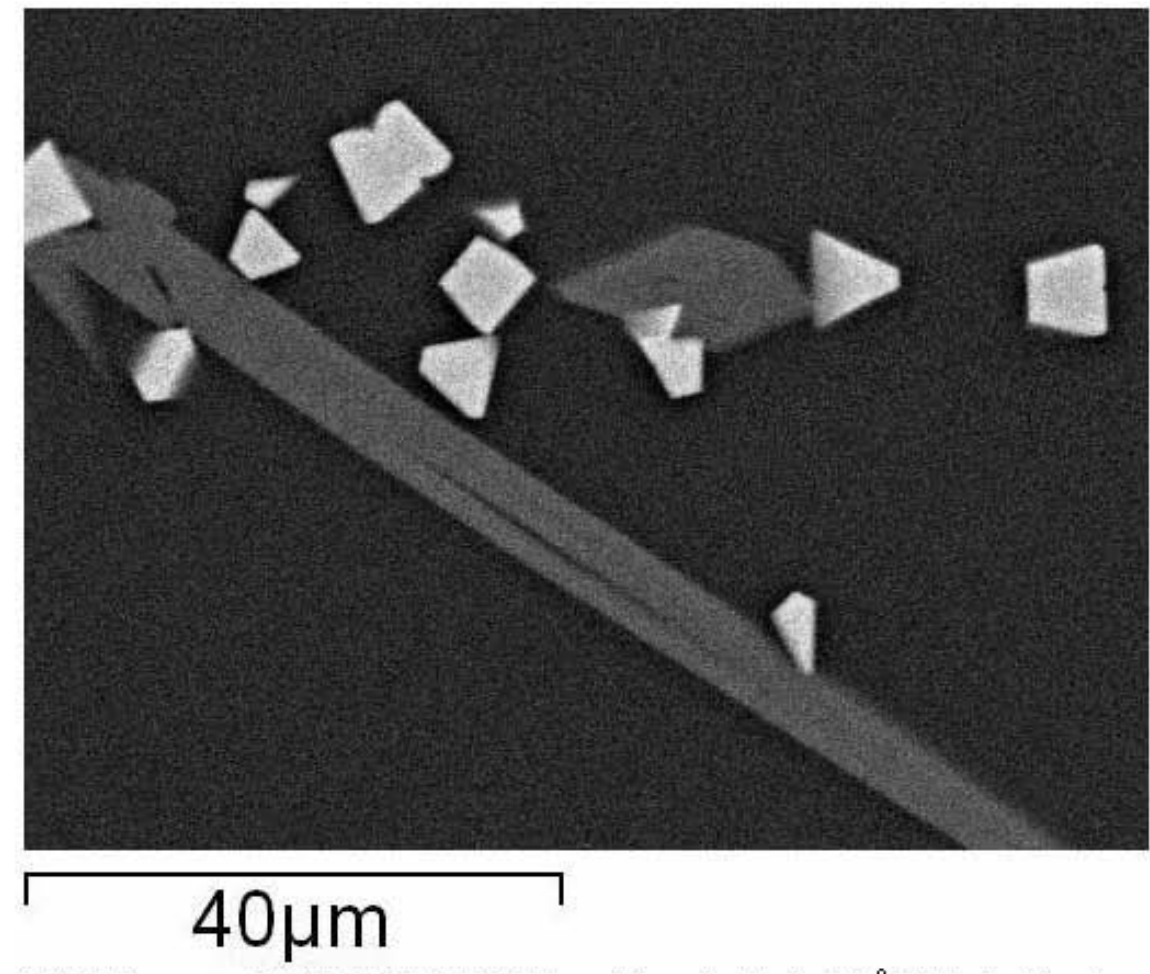

Figure 2d. SEM image of HLWBi2394-3 heat treated at $800^{\circ} \mathrm{C}$ (bright phase: $\mathrm{Fe}-\mathrm{Cr}$-Ni spinel with Mn; grey phase: Apatite). 


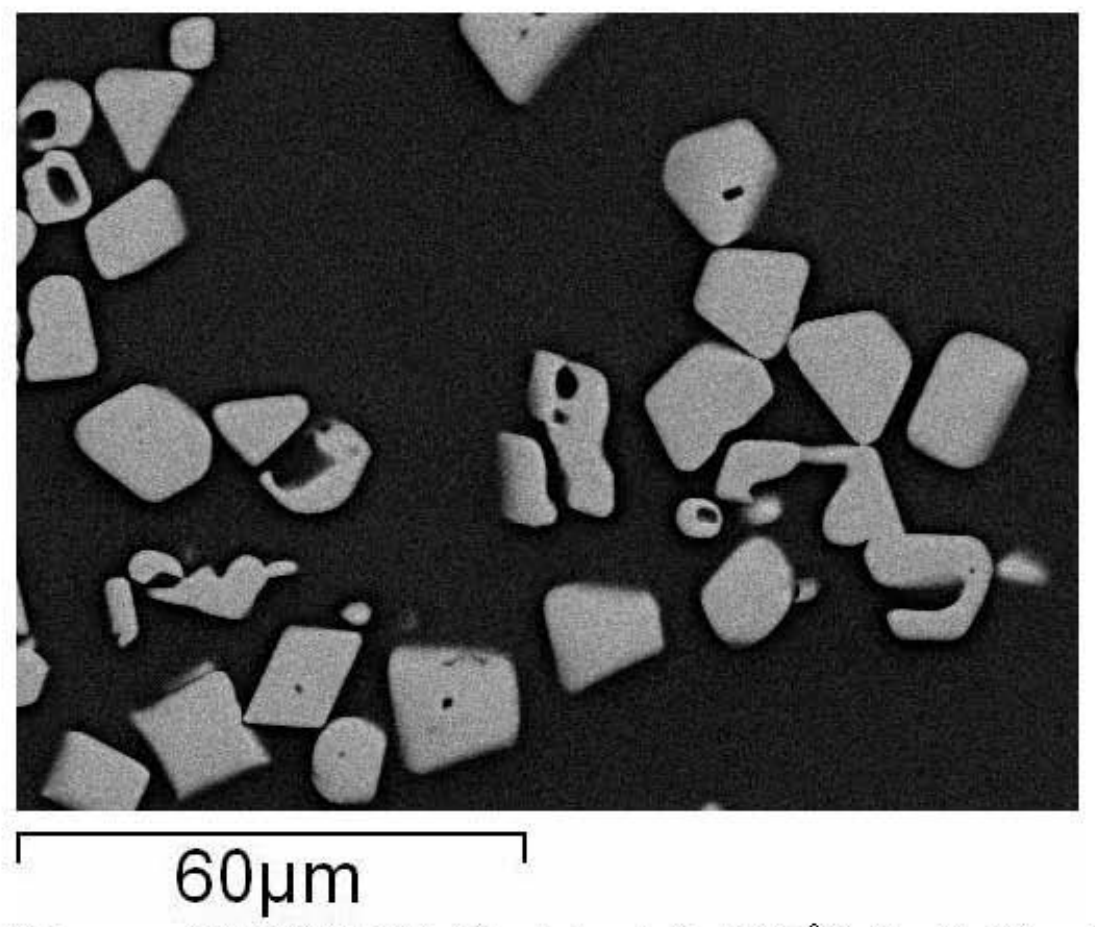

Figure 3a. SEM image of HLWBi2394-4 heat treated at $950^{\circ} \mathrm{C}$ (Fe-Cr-Ni sp inel with Mn).

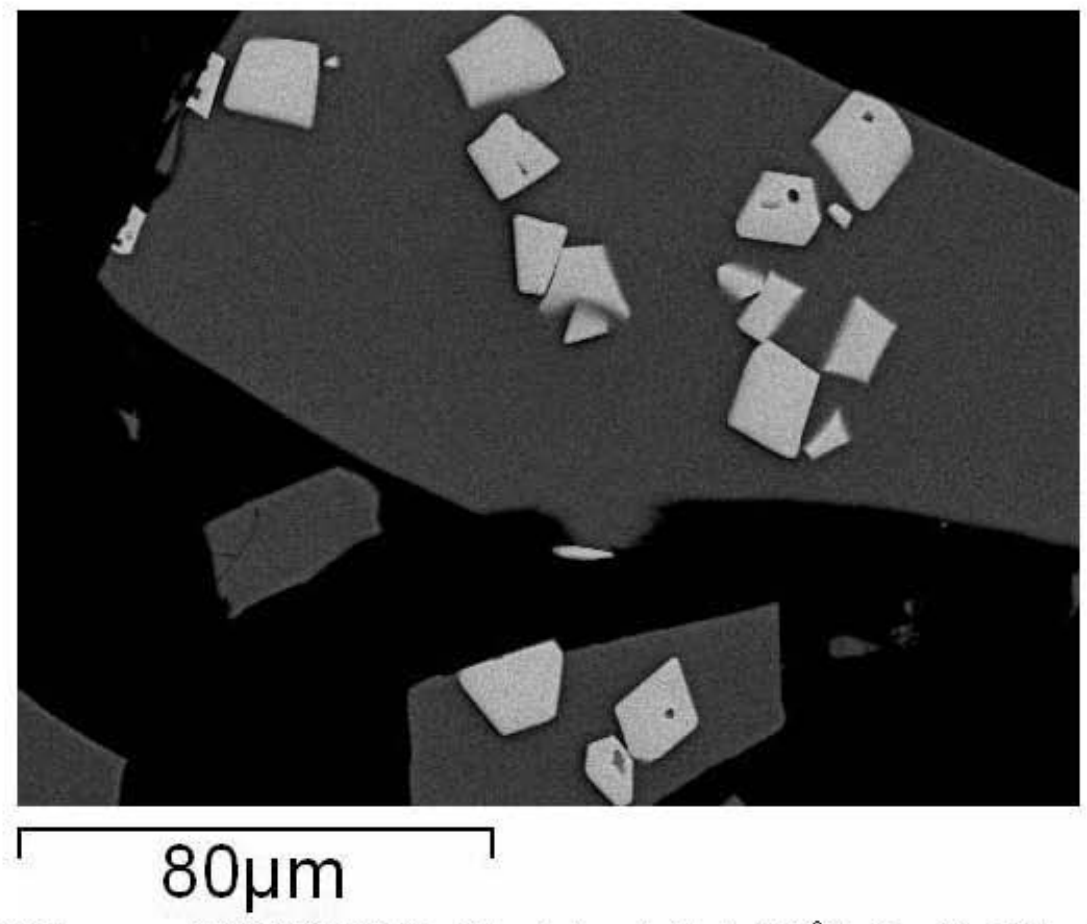

Figure 3b. SEM im age of HLWBi2394-4 heat treated at $900^{\circ} \mathrm{C}$ (F e-Cr-Ni spinel with Mn). 

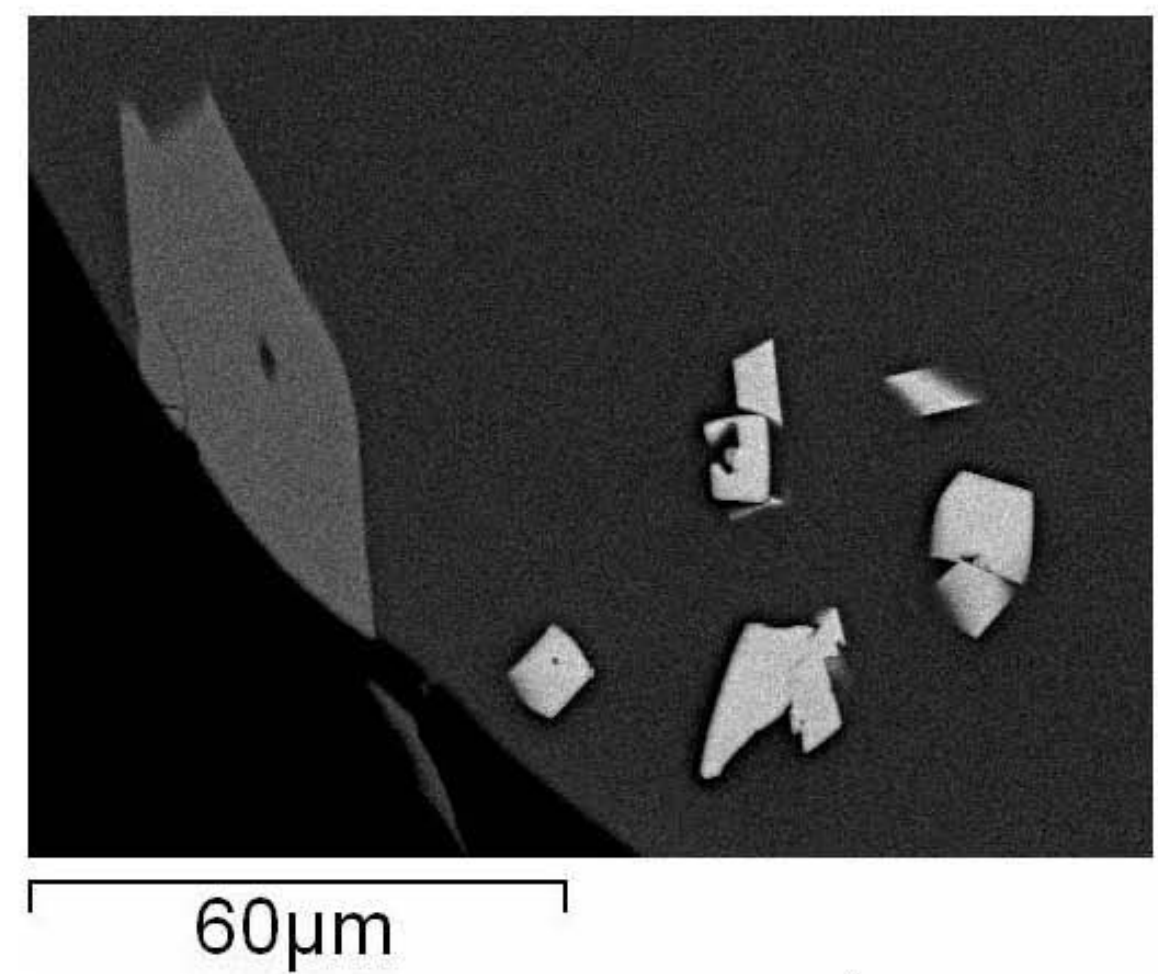

Figure 3c. SEM image of HLWBi2394-4 heat treated at $850^{\circ} \mathrm{C}$ (bright phase: $\mathrm{Cr}$-Fe spinel with $\mathrm{Ni}$ and $\mathrm{Mn}$; grey phase: Apatite).
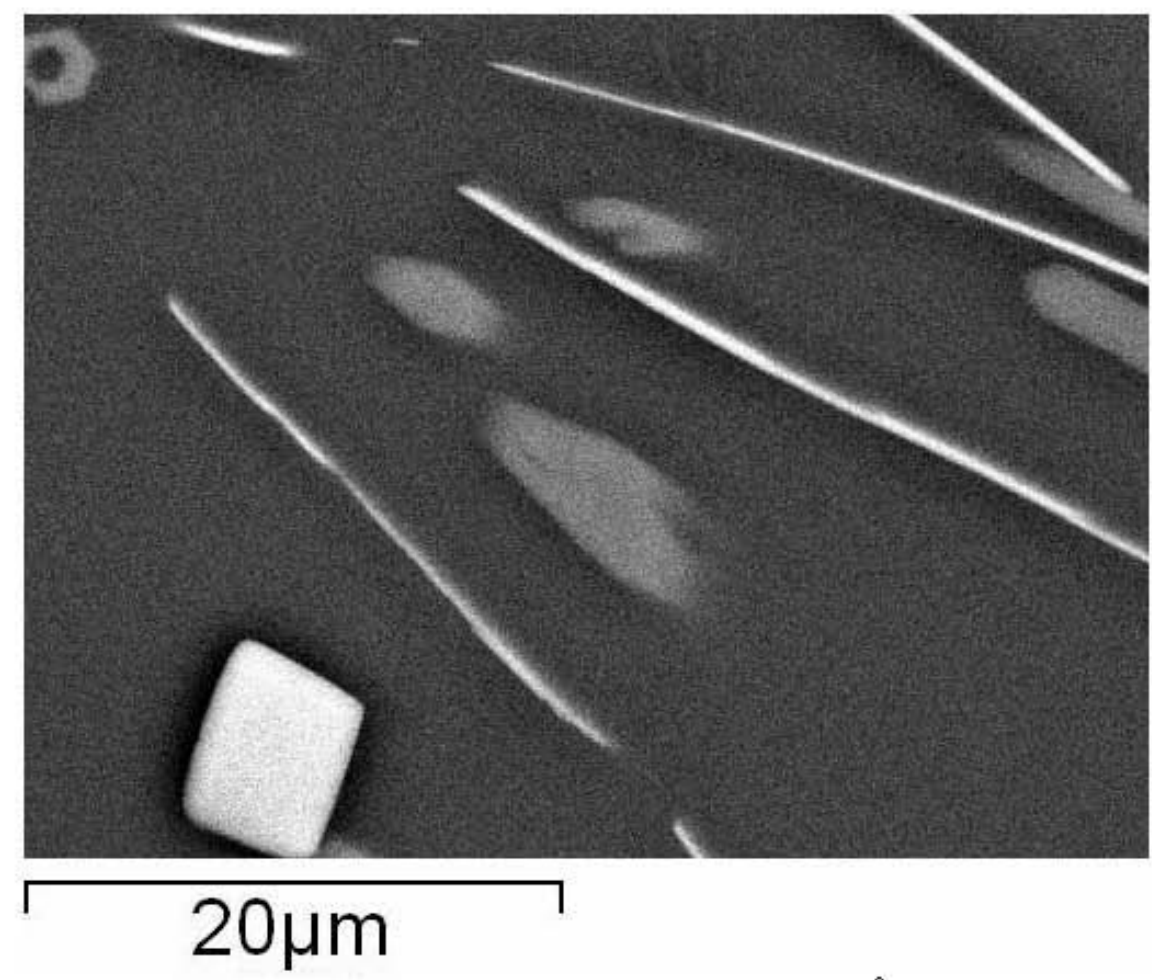

Figure 3d. SEM image of HLWBi2394-4 heat treated at $800^{\circ} \mathrm{C}$ (bright diamond shaped phase: $\mathrm{Fe}-\mathrm{Cr}-\mathrm{Ni}$ spinel with $\mathrm{Mn}$; bright acicular shaped phase: $\mathrm{Fe}-\mathrm{Cr}$ oxide; grey phase: Apatite). 
The Catholic University of America

Vitreous State Laboratory
Development of High Waste Loading HLW Glasses for High Bismuth Phosphate Wastes Final Report, VSL-12R2550-1, Rev. 0

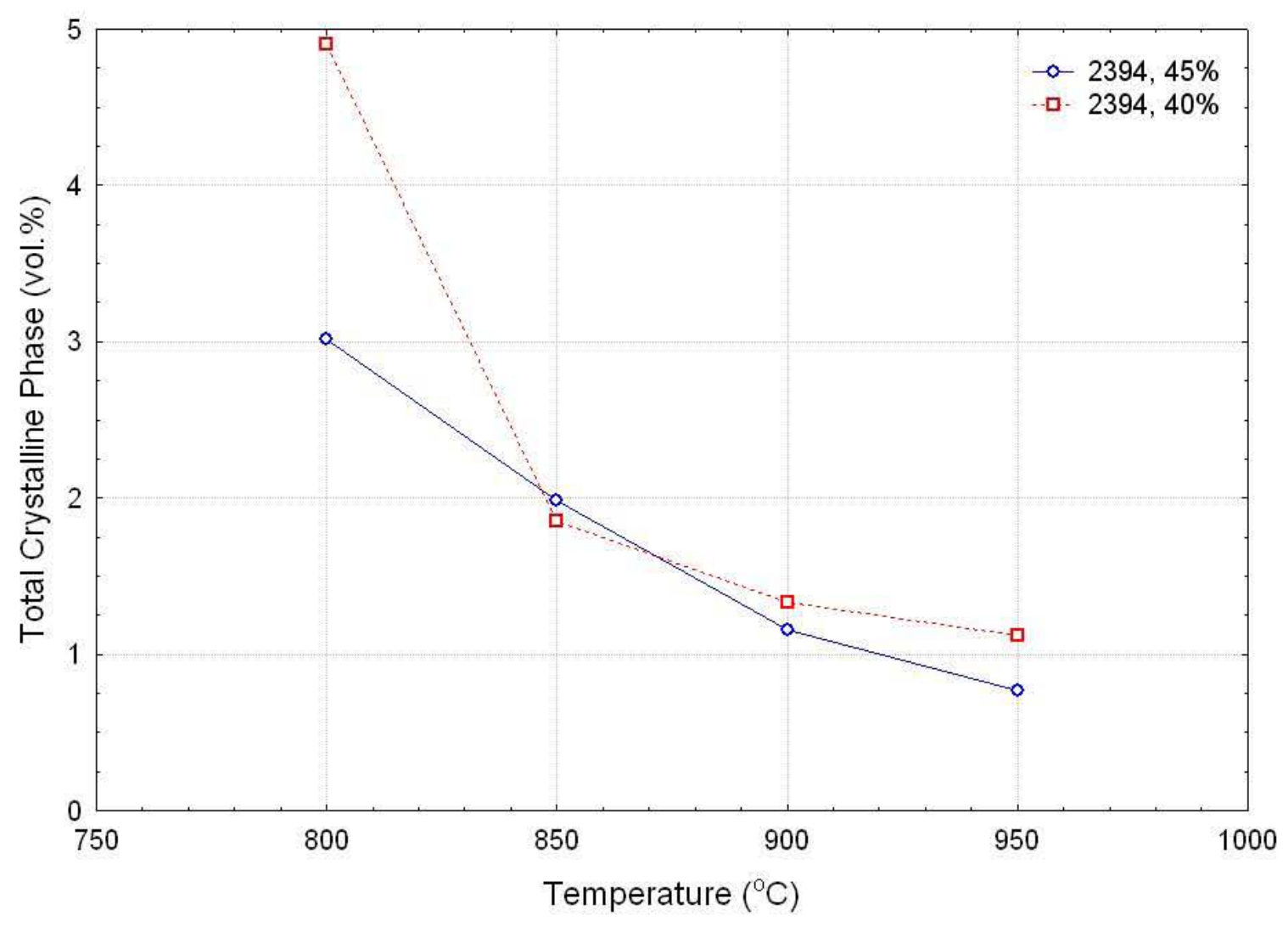

Figure 4. Total amount of crystalline phases (vol\%) after isothermal heat treatment of HWBi2394-3 (45 wt\% waste loading, blue open circles) and HWBi2394-4 (40 wt\% waste loading, red open squares). 
The Catholic Univer sity of America Vitreaus State Laboratory
Development of High Waste Loading HLW Glasses for High Bismuth Phosphate Wastes Final Report, VSL-12R2550-1, Rev. 0

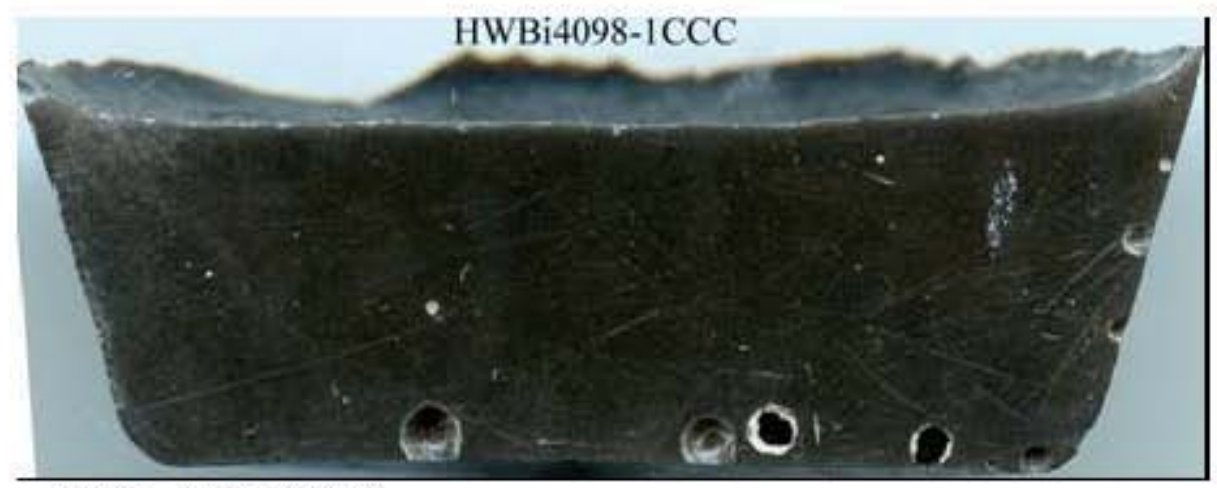

HWBi-4098-1CCC

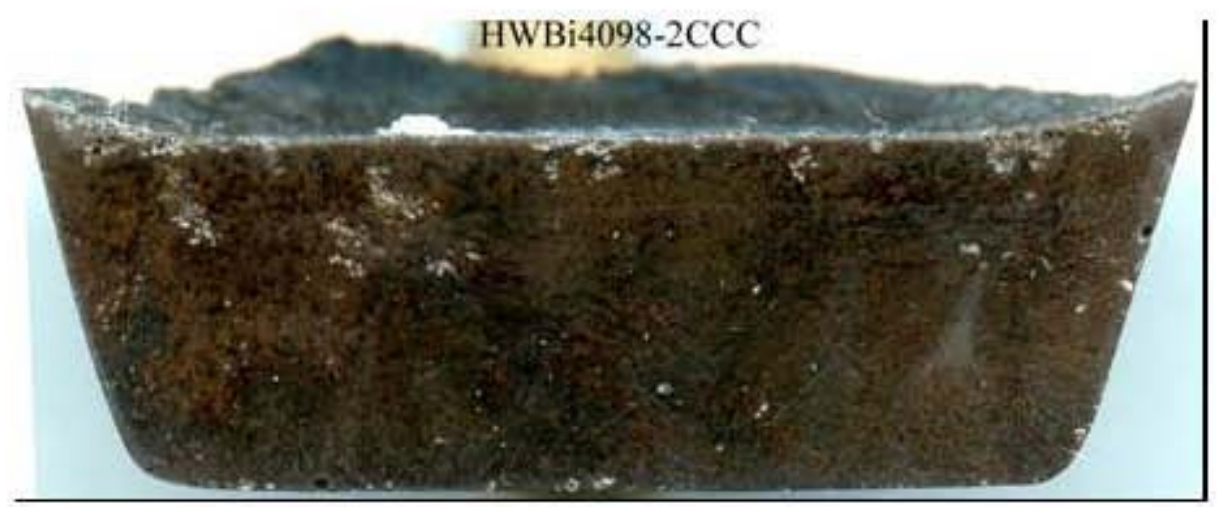

$\mathrm{HWBi}-4098-2 \mathrm{CCC}$

HWBi4098-3CCC

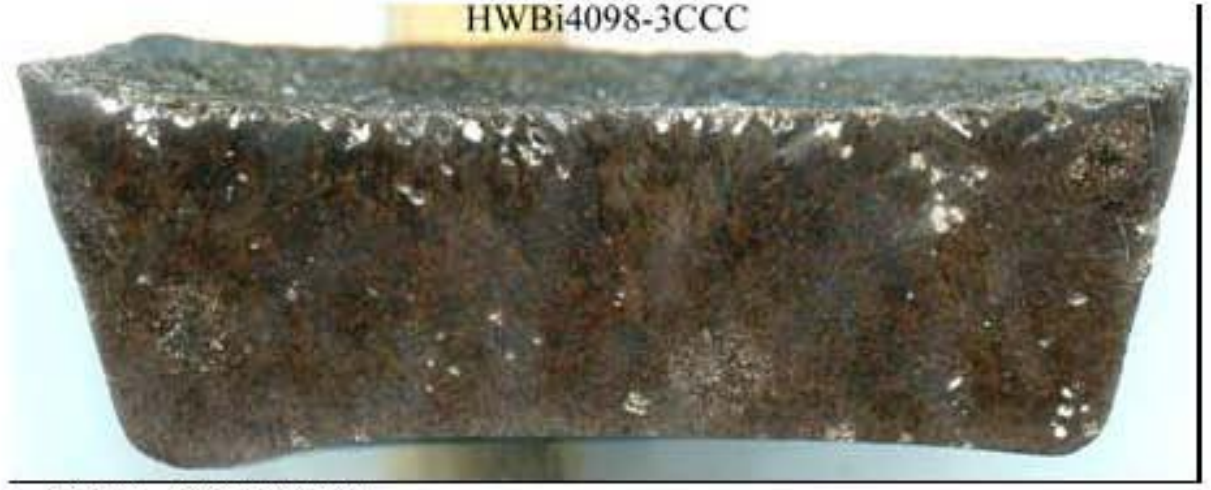

$\mathrm{HWBi}-4098-3 \mathrm{CCC}$

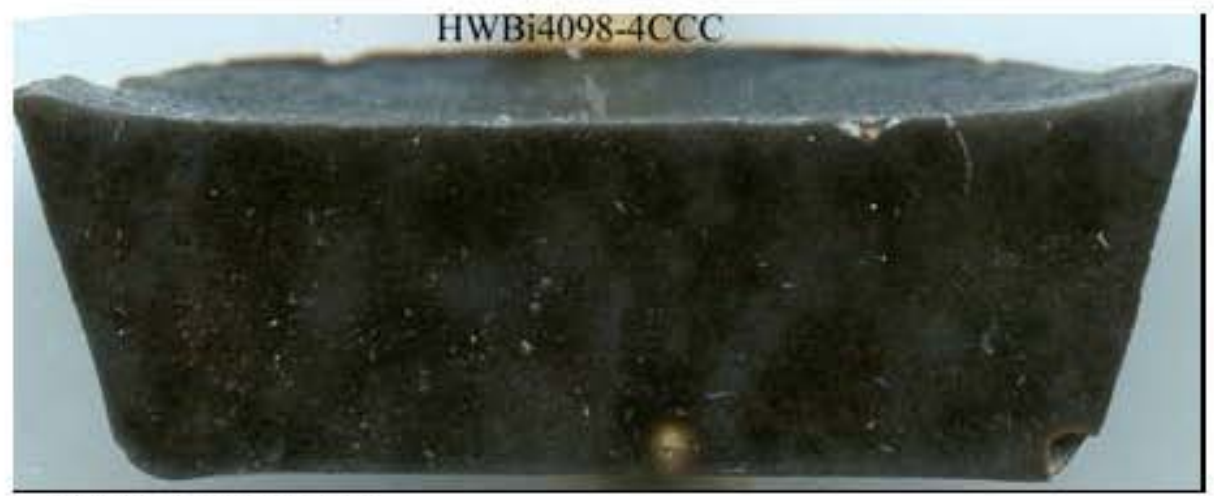

$\mathrm{HWBi}-4098-4 \mathrm{CCC}$

Figure 5. Cross sections of glass CCC samples of Waste Batch 4098. 
The Catholic Univer sity of America Vitreous State Laboratory
Development of High Waste Loading HLW Glasses for High Bismuth Phosphate Wastes Final Report, VSL-12R2550-1, Rev. 0

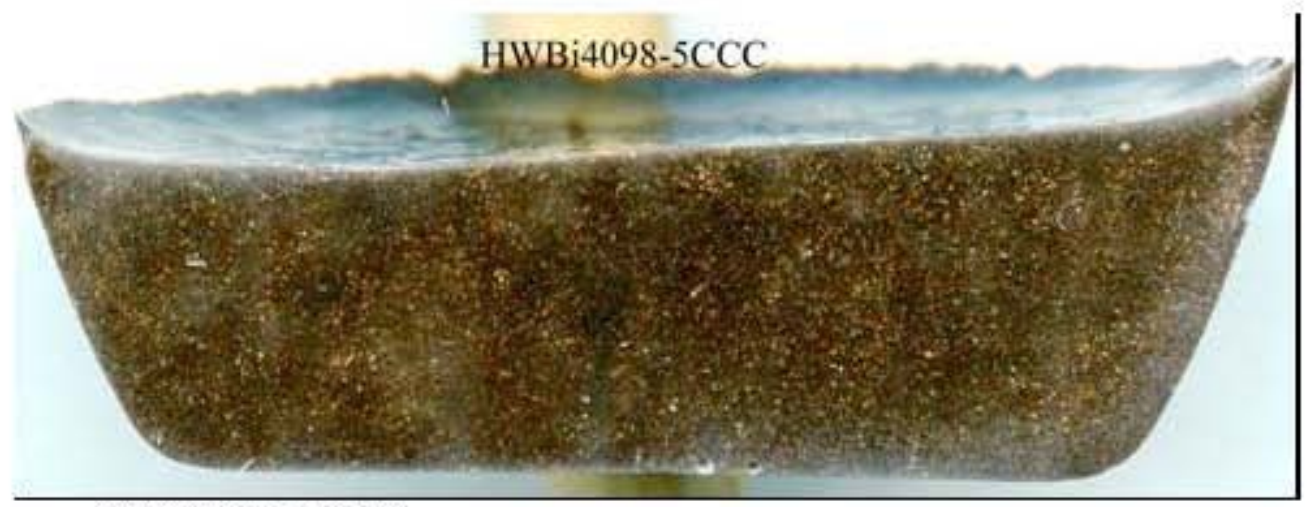

HWBi4098-5CCC

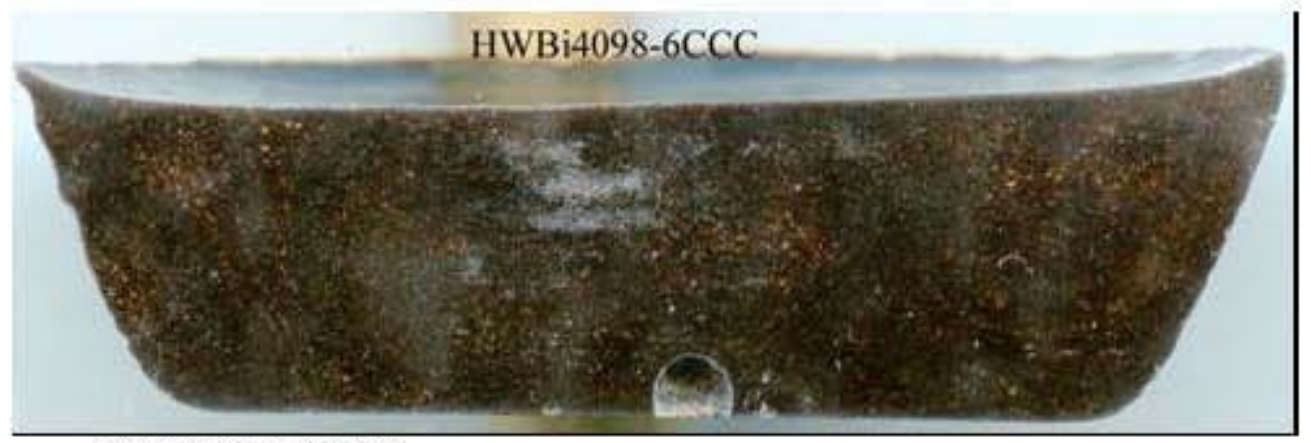

HWBi4098-6CCC

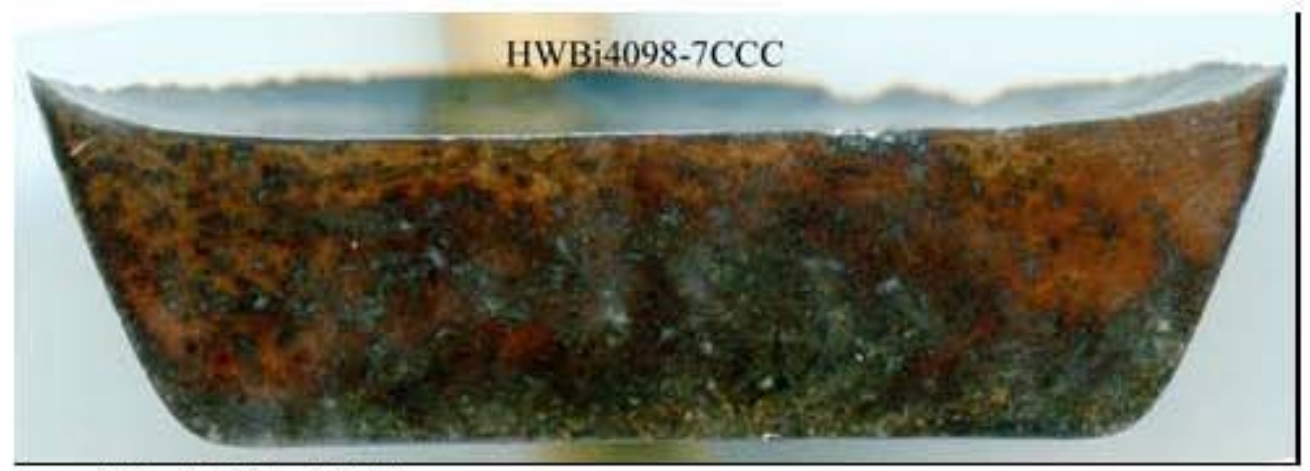

HWBi4098-7CCC

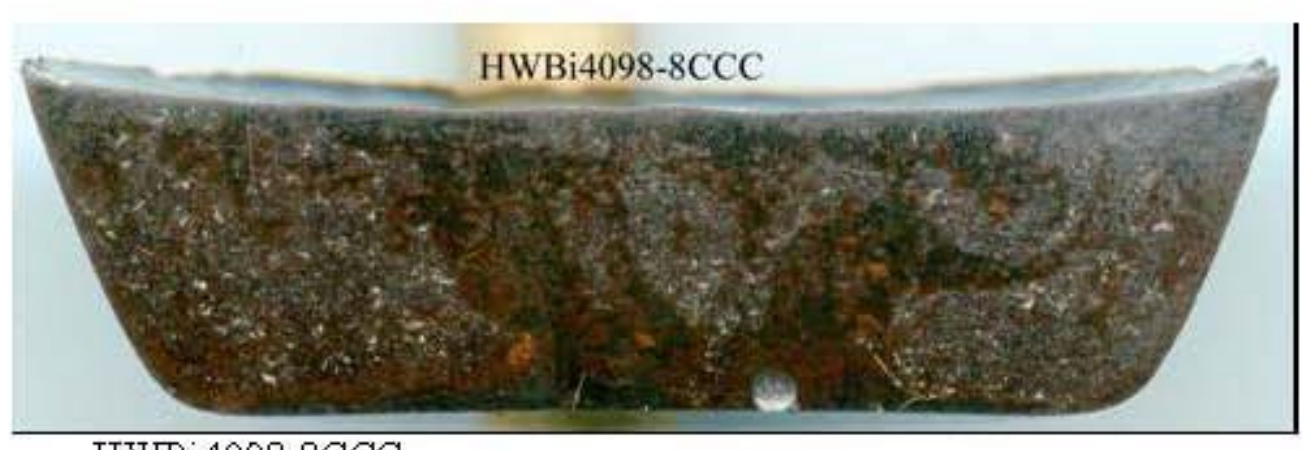

HWBi4098-8CCC

Figure 5. Cross sections of glass $\mathrm{CCC}$ samples of Waste Batch 4098 (continued). 
The Catholic Univer sity of America Vitreous State Laboratory
Development of High Waste Loading HLW Glasses for High Bismuth Phosphate Wastes Final Report, VSL-12R2550-1, Rev. 0

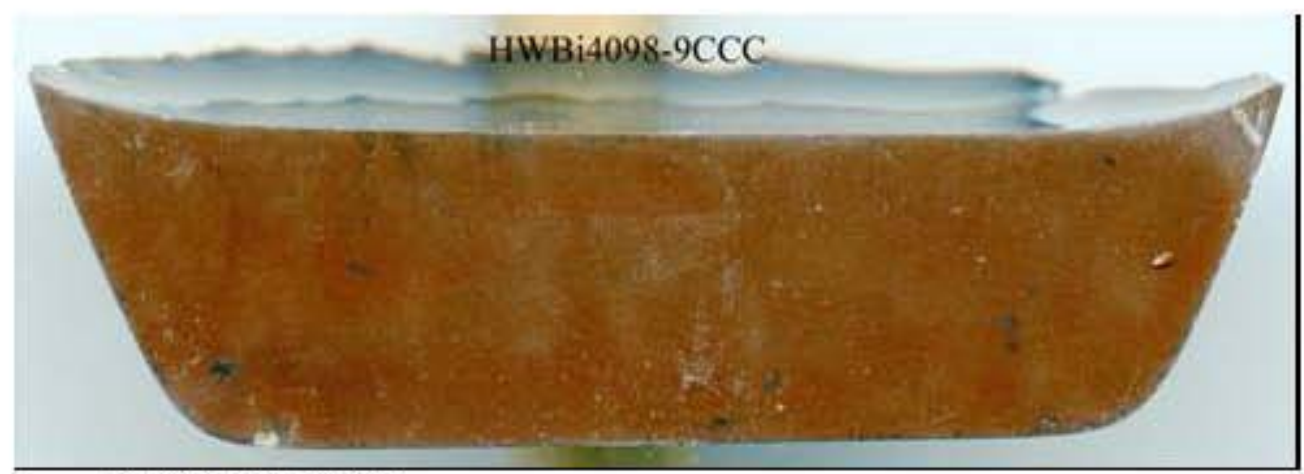

HWBi4098-9CCC

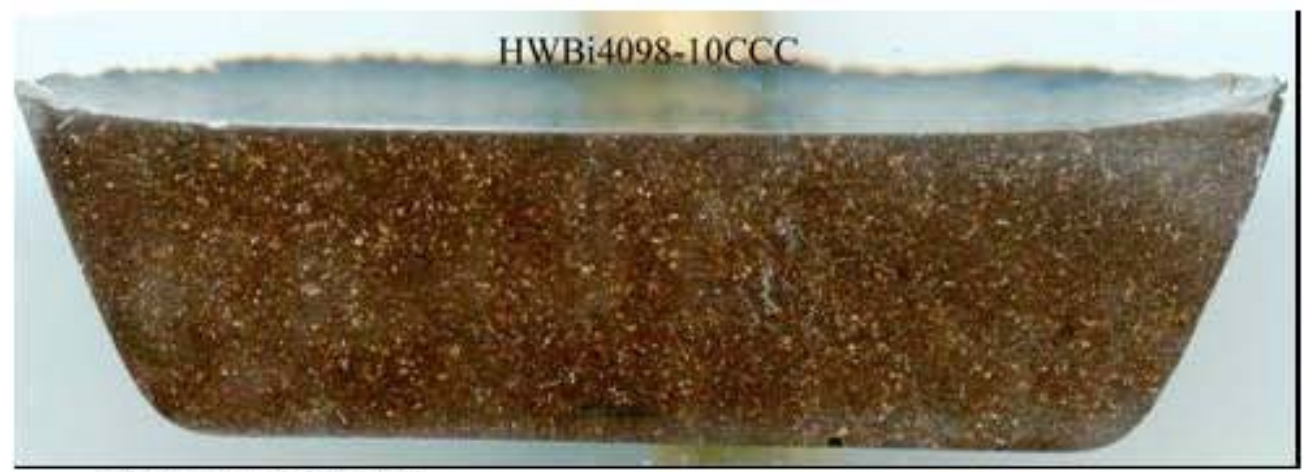

HWBi4098-10CCC

Figure 5. Cross sections of glass CCC samples of Waste Batch 4098 (continued). 


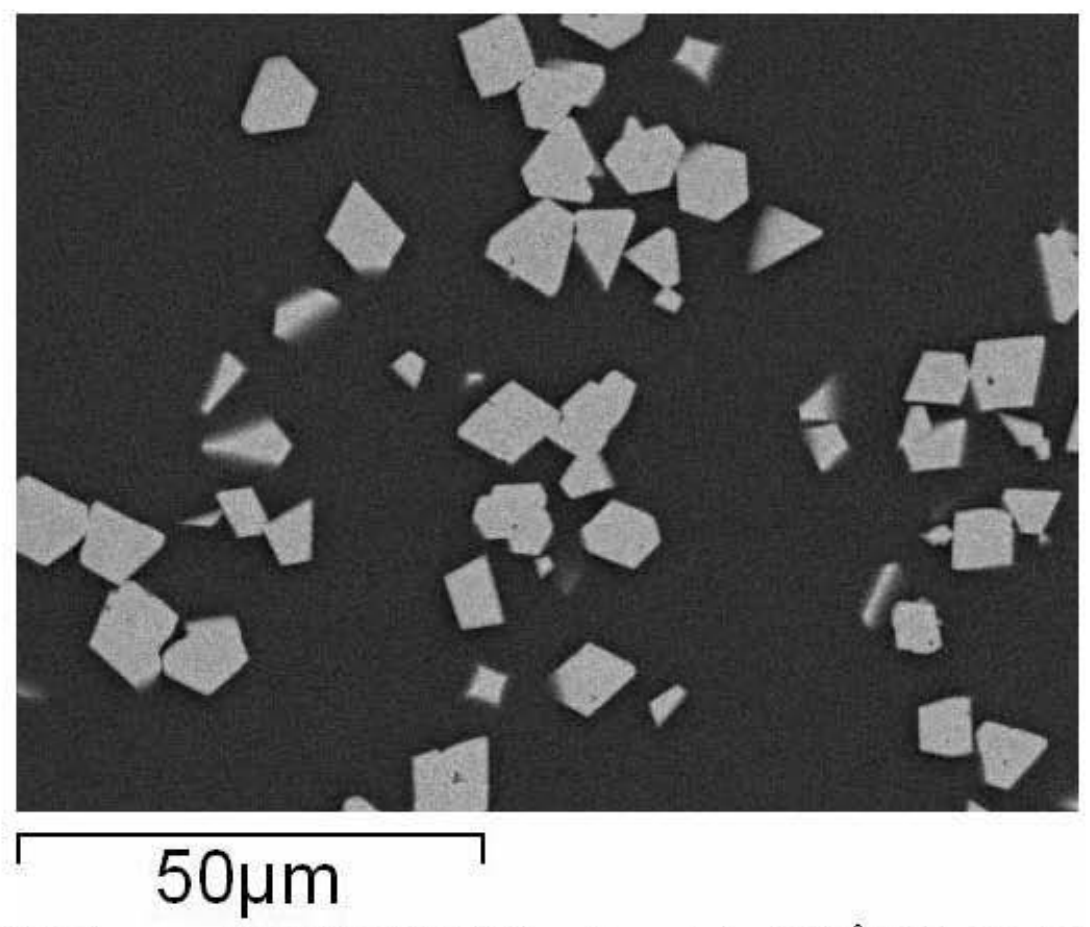

Figure 6a. SEM im age of HLWBi4098-6 heat treated at $950^{\circ} \mathrm{C}$ (Cr-Fe-Mn-Ni spinel).

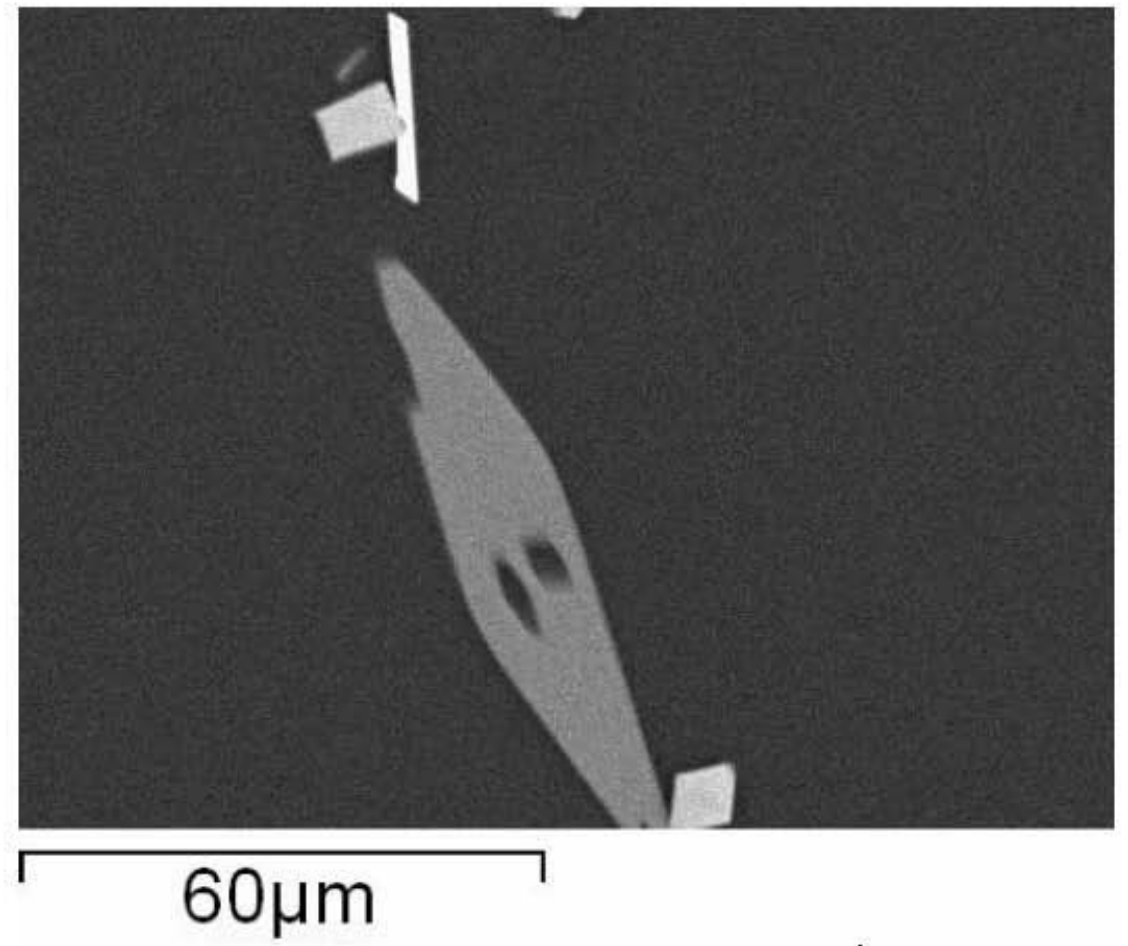

Figure 6b. SEM image of HLWBi4098-6 heat treated at $900^{\circ} \mathrm{C}$ (bright diam ond shaped phase: Cr-Fe-Mn-Ni spinel; grey phase: Apatite; very bright platelet: La-phosphate). 


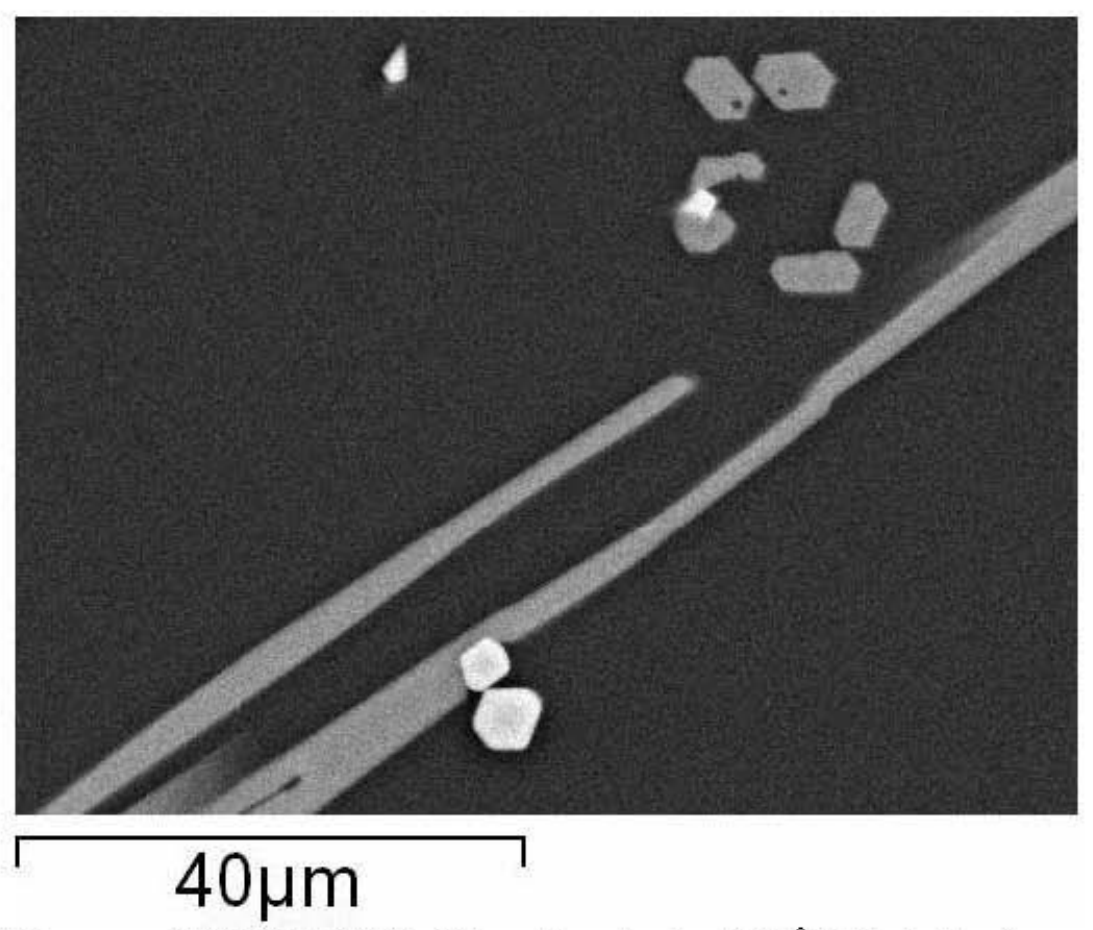

Figure 6c. SEM im age of HLWBi4098-6 heat treated at $850^{\circ} \mathrm{C}$ (bright phase: $\mathrm{Cr}-\mathrm{Fe}-\mathrm{Mn}-\mathrm{Ni}$ spinel; grey phase: Apatite).

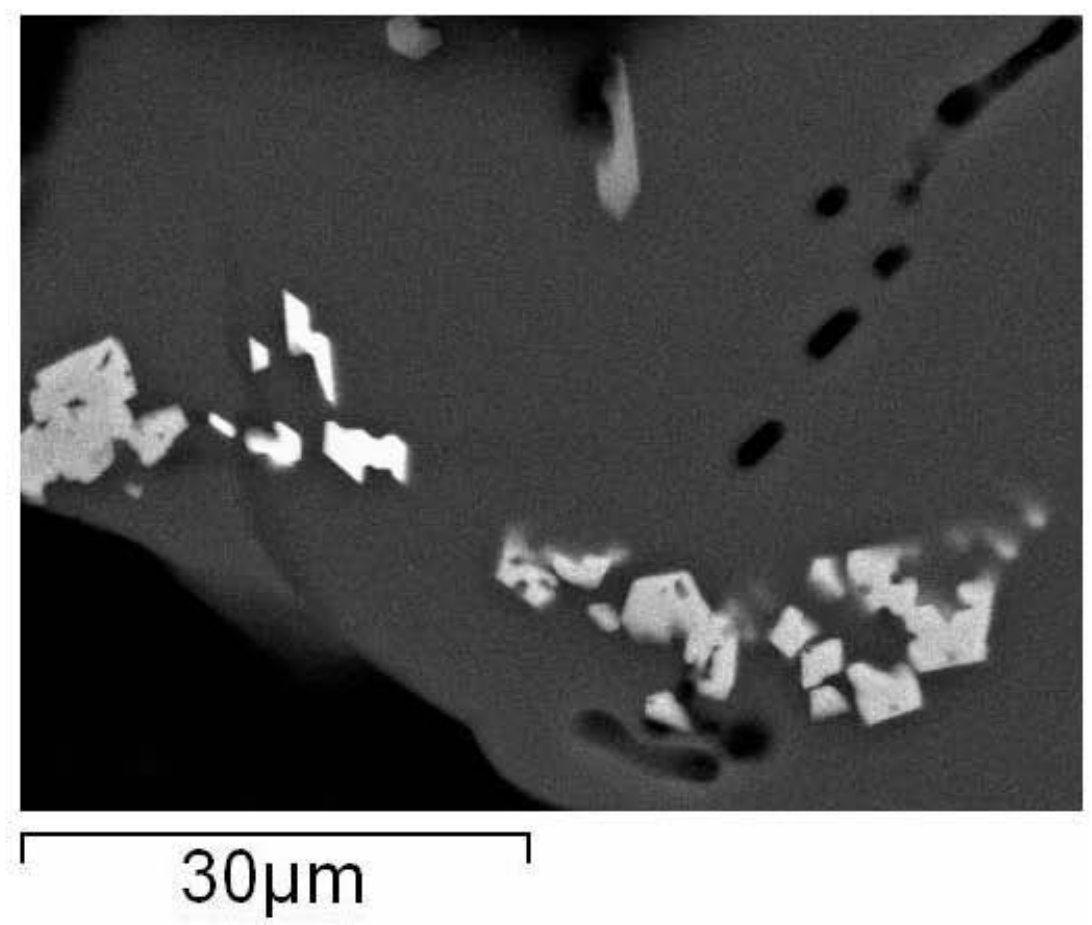

Figure 6d. SEM image of HLWBi4098-6 heat treated at $800^{\circ} \mathrm{C}$ (light grey diam ond shaped clusters : $\mathrm{Cr}-\mathrm{Fe}-\mathrm{Mn}-\mathrm{Ni}$ spinel; grey phase near top center: Apatite; very bright ph ase near center: La-phosphte; black segmented cavity: probably voids created by dissolution of alkaline ph osph ate during sample polishing). 


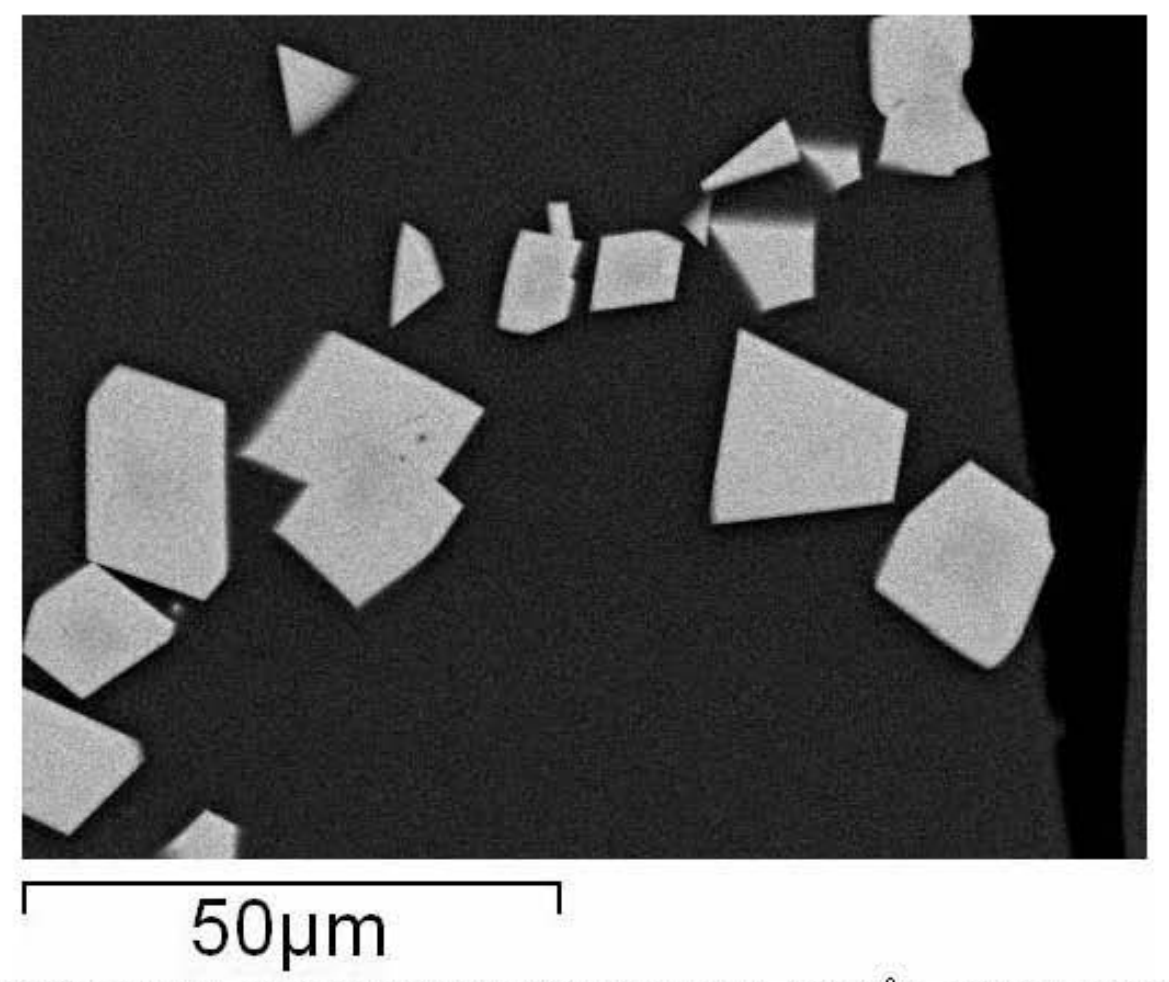

Figure 7a. SEM image of $\mathrm{HLWBi4098-7} \mathrm{heat} \mathrm{treated} \mathrm{at} 950^{\circ} \mathrm{C}$ (Cr-Fe-Mn-Ni spinel).
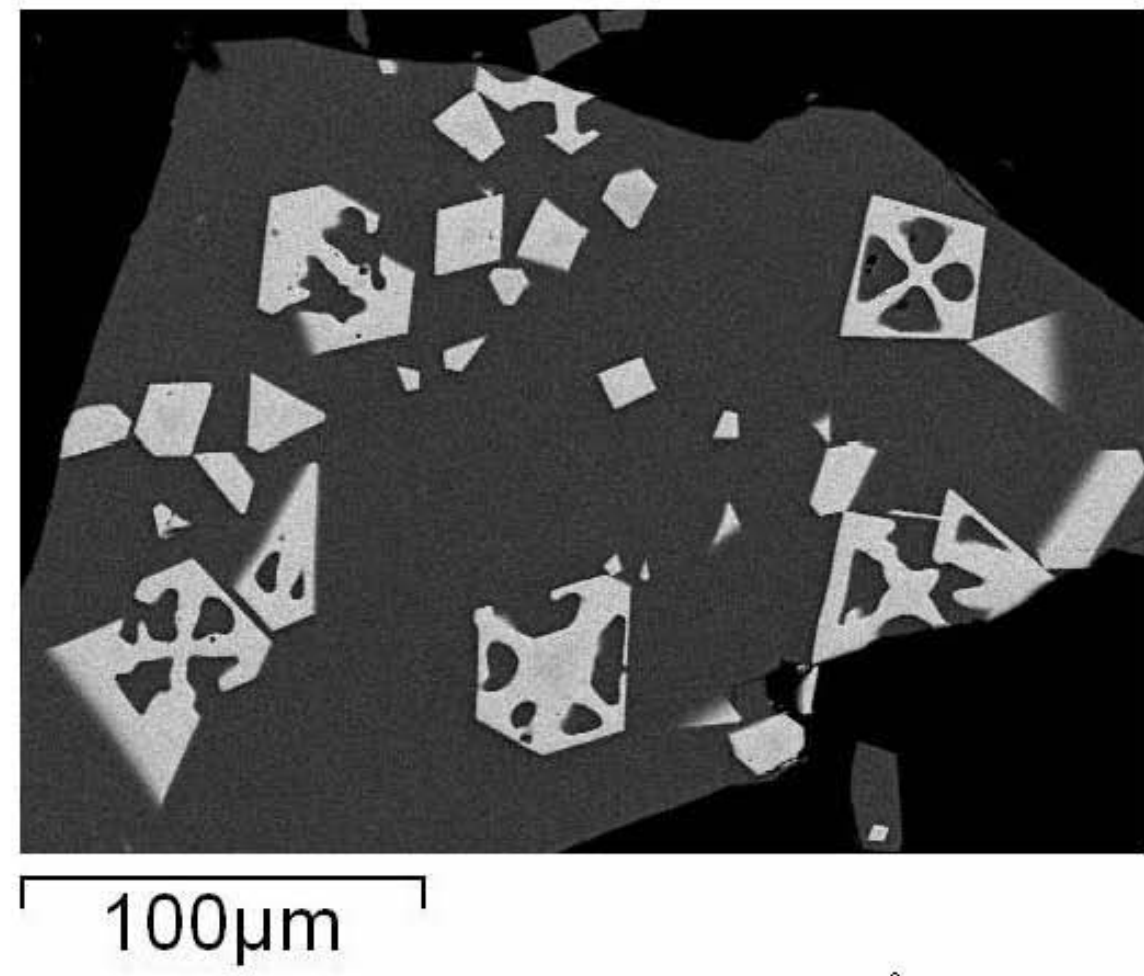

Figure $7 \mathrm{~b}$. SEM image of $\mathrm{HL}$ WBi4098- 7 heat treated at $900^{\circ} \mathrm{C}$ (Cr-Fe-Mn-Ni spinel). 


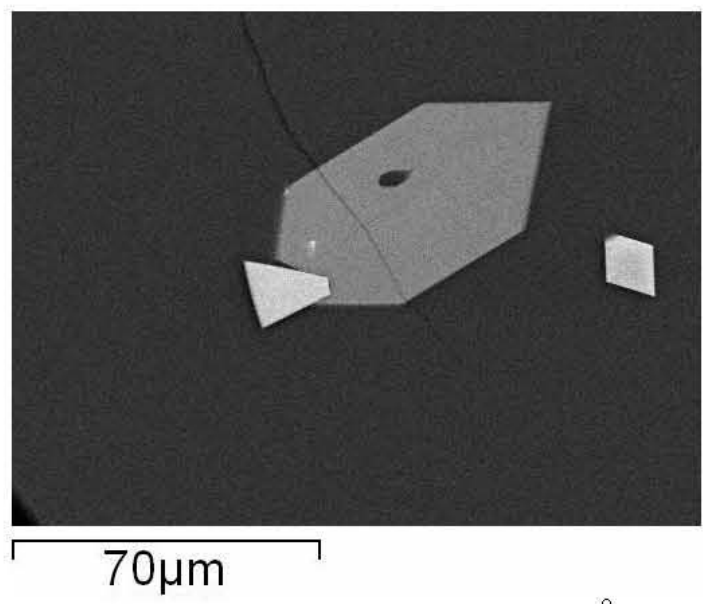

Figure 7c. SEM image of HLWBi4098-7 heat treated at $850 \mathrm{C}$ (bright phase: $\mathrm{Cr}-\mathrm{Fe}-\mathrm{Mn}-\mathrm{Ni}$ spinel; grey phase: Apatite).

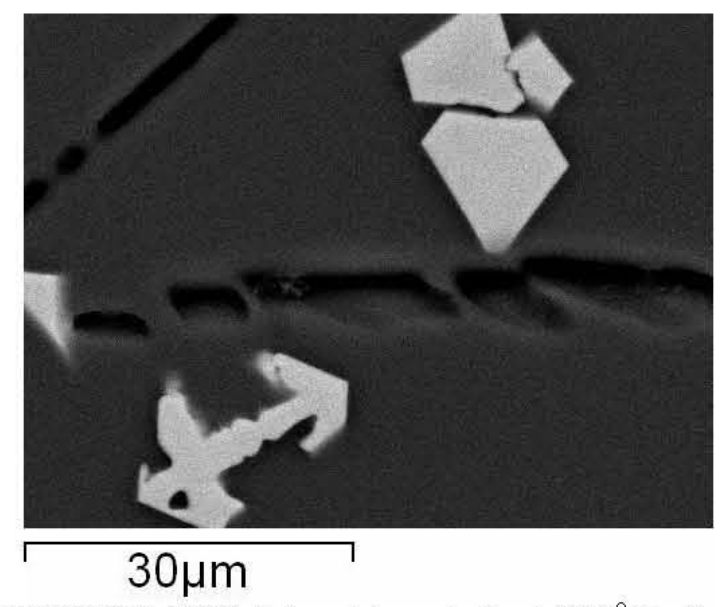

Figure 7d. SEM image of HLWBi4098-7 heat treated at $800^{\circ} \mathrm{C}$ (bright phase: $\mathrm{Cr}-\mathrm{Fe}-\mathrm{Mn}-\mathrm{Ni}$ spinel; black segmented cavity: Probably voids from alkaline phosphate dissolved during sample polishing).

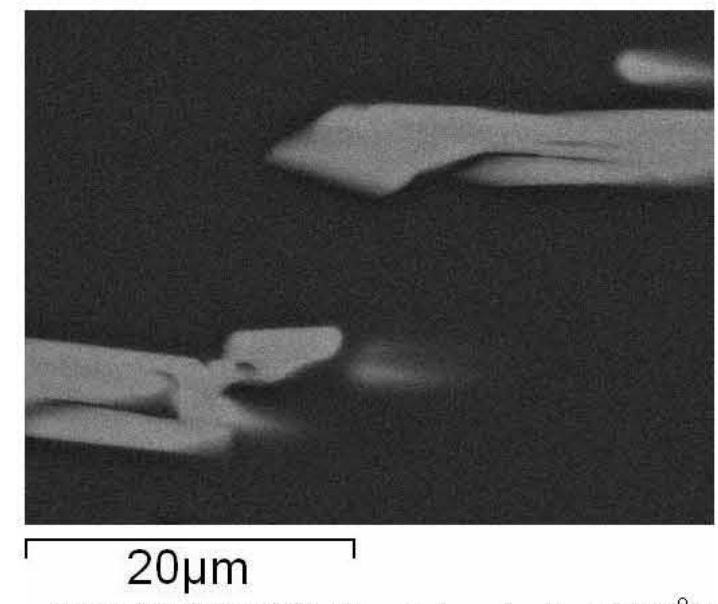

Figure 7e. SEM image of HLWBi4098-7 heat treated at $800 \mathrm{C}$ (grey phase: Apatite). 


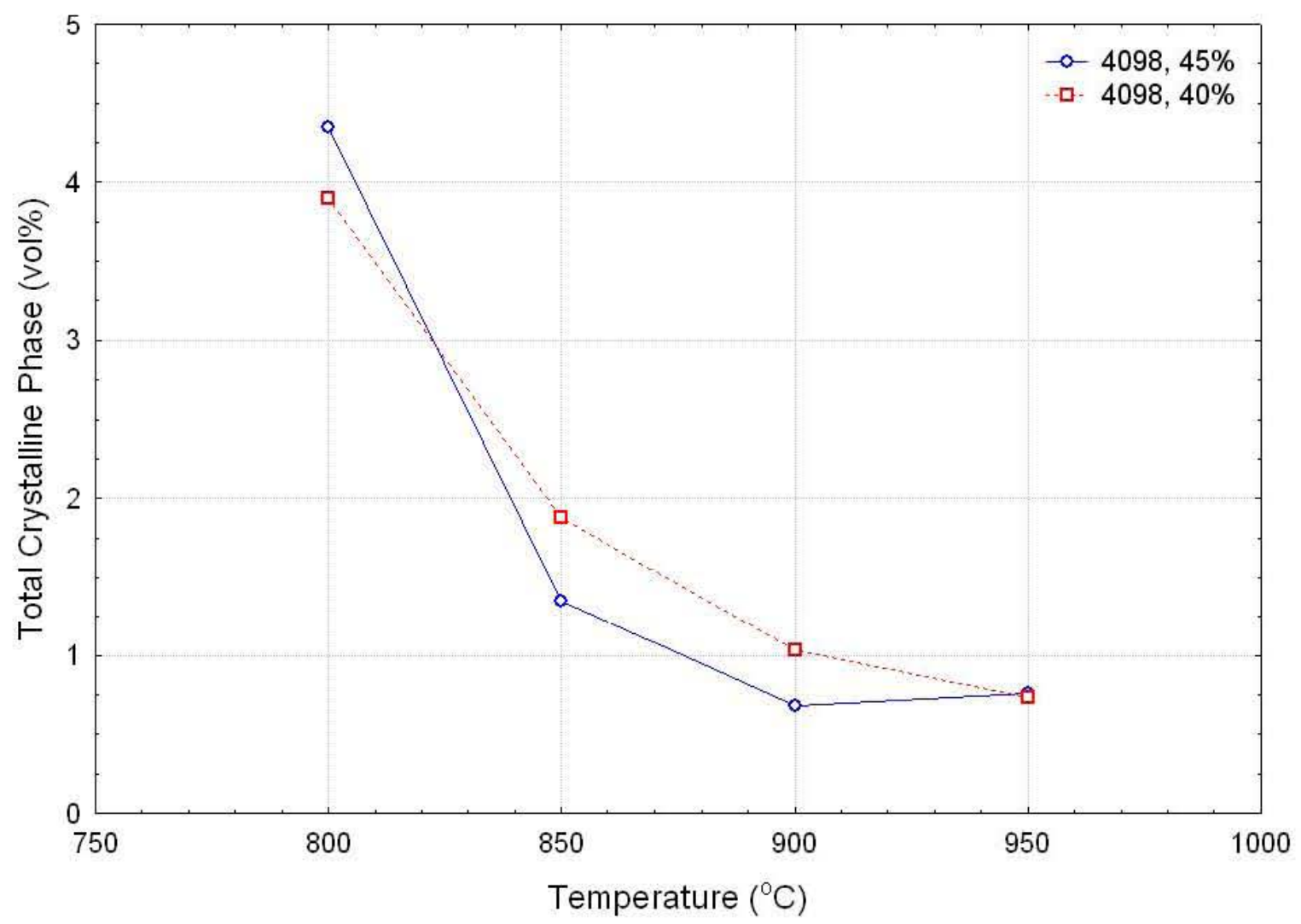

Figure 8. Total amount of crystalline phases (vol\%) after isothermal heat treatment of HWBi4098-7 (45 wt\% waste loading, blue open circles) and HWBi4098-6 (40 wt\% waste loading, red open squares). 
The Catholic Univer sity of America Vitreaus State Laboratory
Development of High Waste Loading HLW Glasses for High Bismuth Phosphate Wastes Final Report, VSL-12R2550-1, Rev. 0

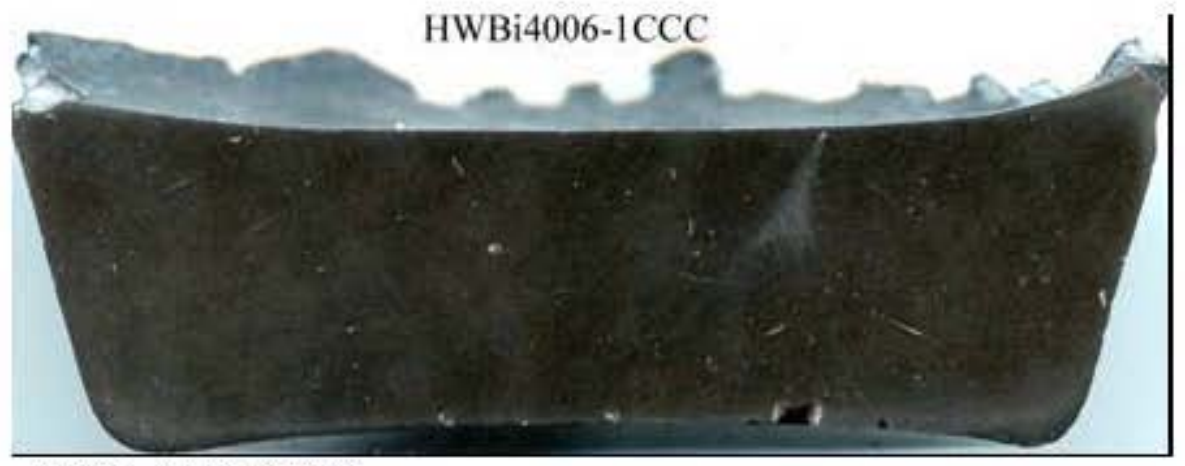

$\mathrm{HWBi}-4006-1 \mathrm{CCC}$

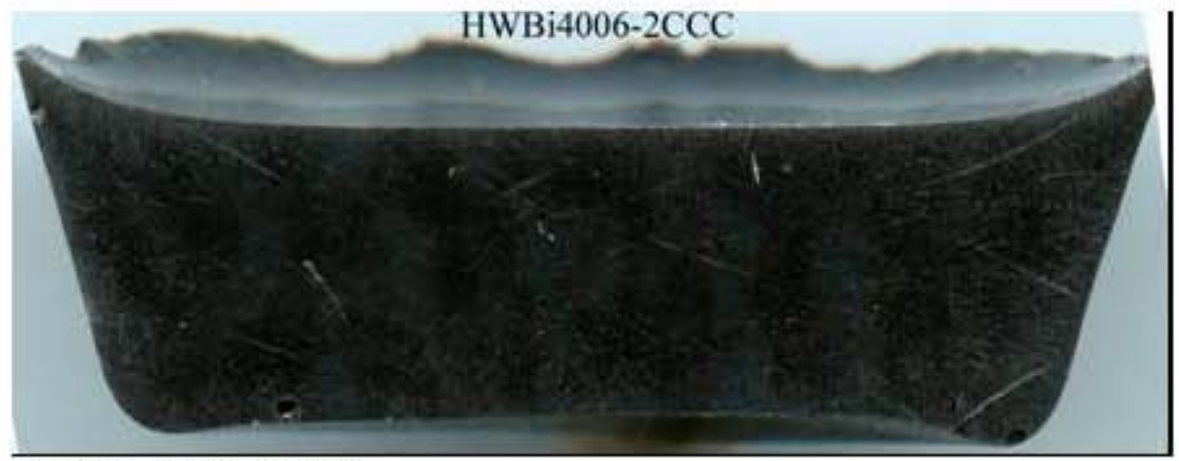

$\mathrm{HWBi}-4006-2 \mathrm{CCC}$

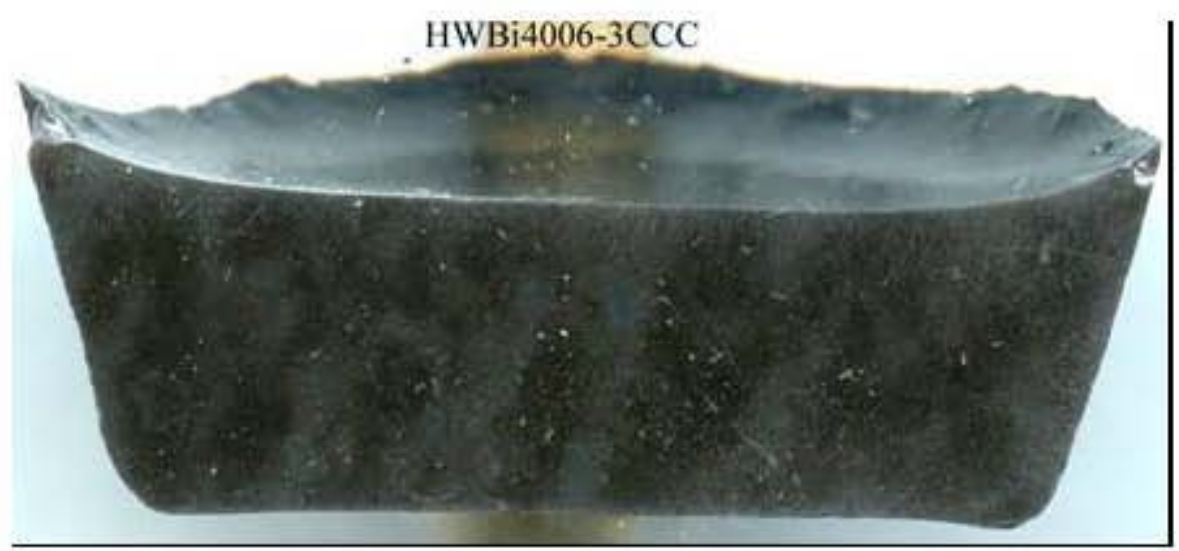

$\mathrm{HWBi}-4006-3 \mathrm{CCC}$

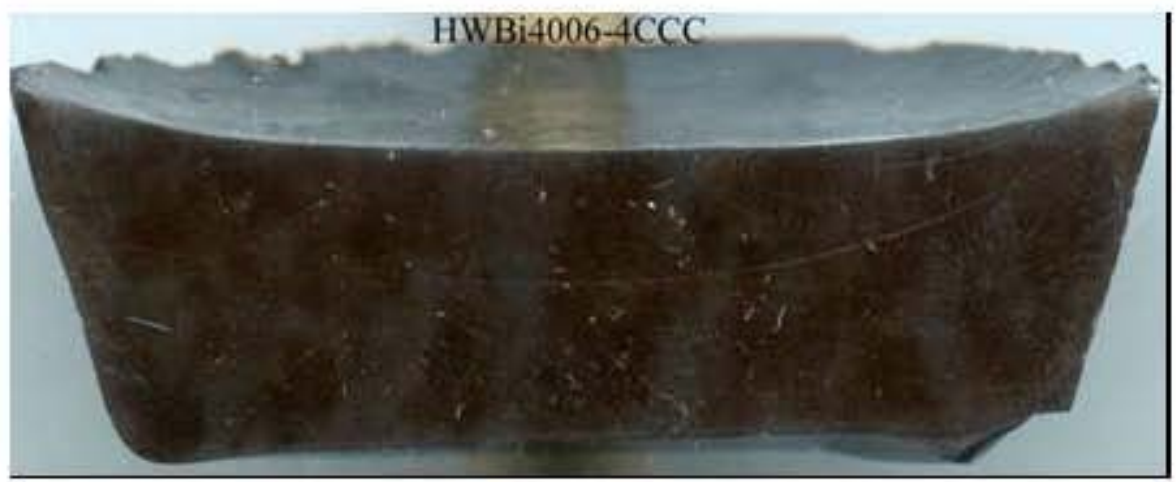

$\mathrm{HWBi}-4006-4 \mathrm{CCC}$

Figure 9. Cross sections of glass CCC samples of Waste Batch 4006. 
The Catholic Univer sity of America Vitreaus State Laboratory
Development of High Waste Loading HLW Glasses for High Bismuth Phosphate Wastes Final Report, VSL-12R2550-1, Rev. 0

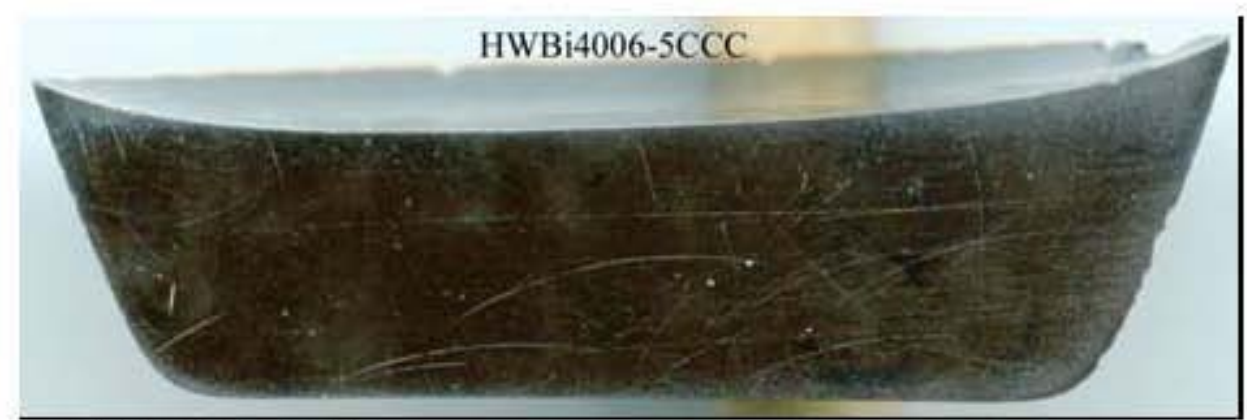

HWBi4006-5CCC

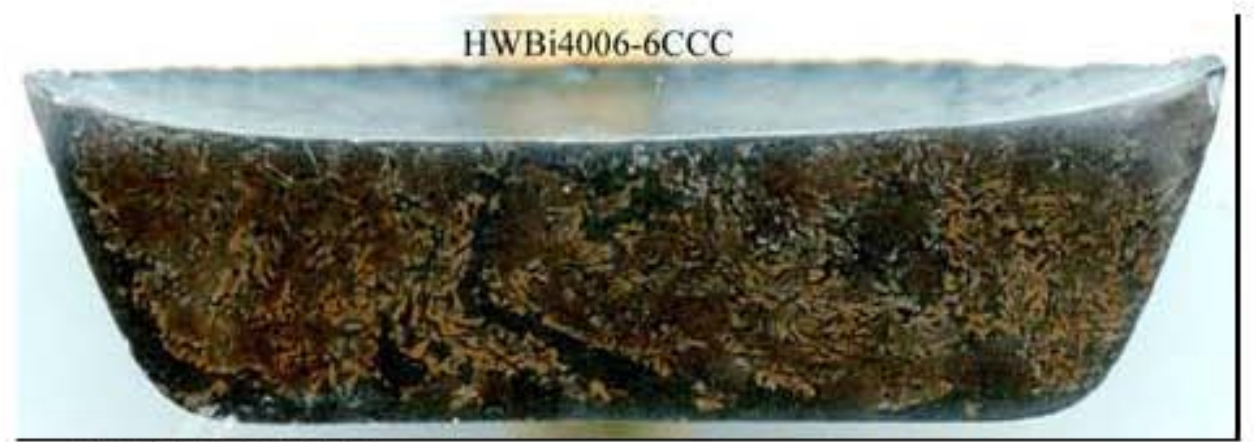

HWBi4006-6CCC

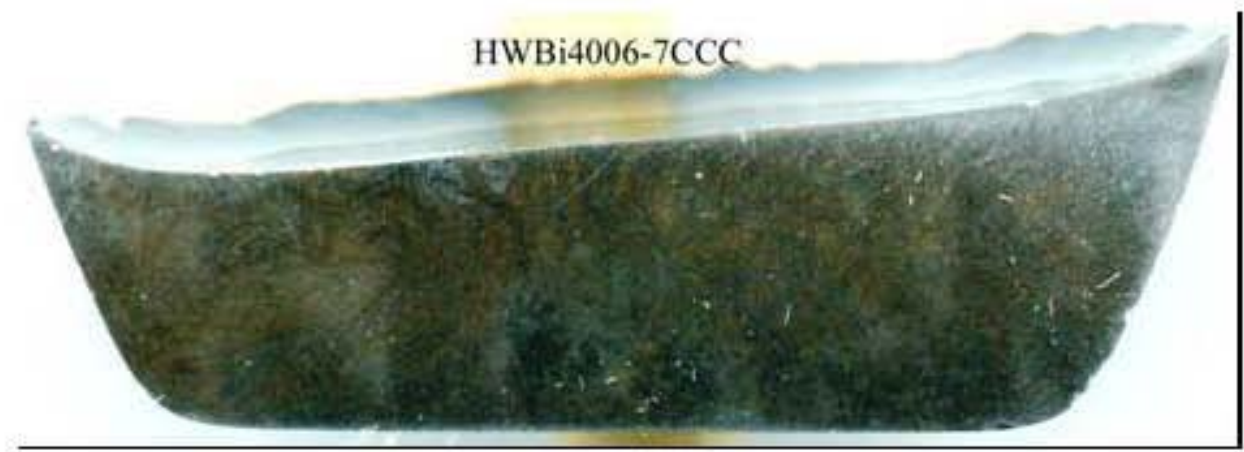

HWBi4006-7CCC

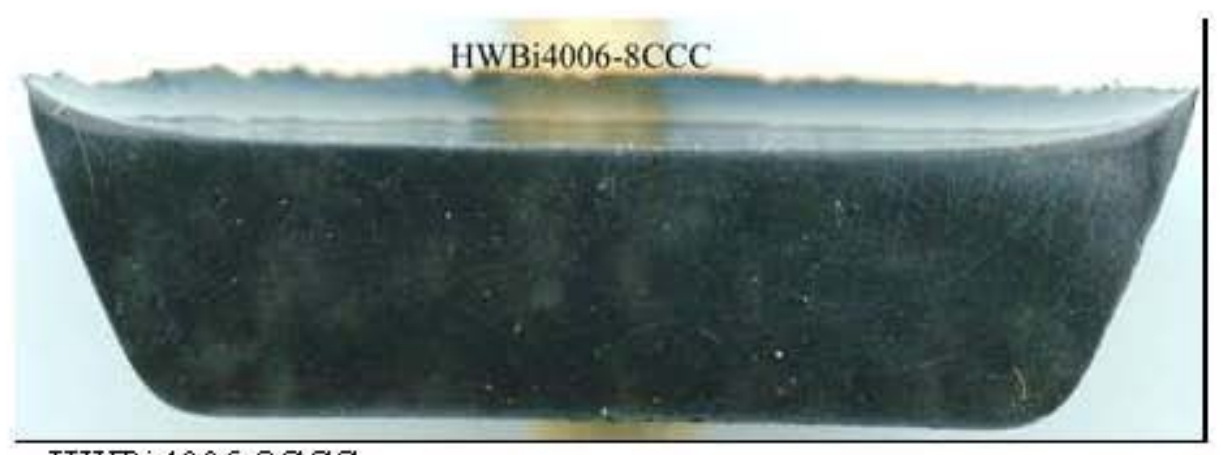

HWBi4006-8CCC

Figure 9. Cross sections of glass CCC samples of Waste Batch 4006 (continued). 
The Catholic Univer sity of America Vitreous State Laboratory
Development of High Waste Loading HLW Glasses for High Bismuth Phosphate Wastes Final Report, VSL-12R2550-1, Rev. 0

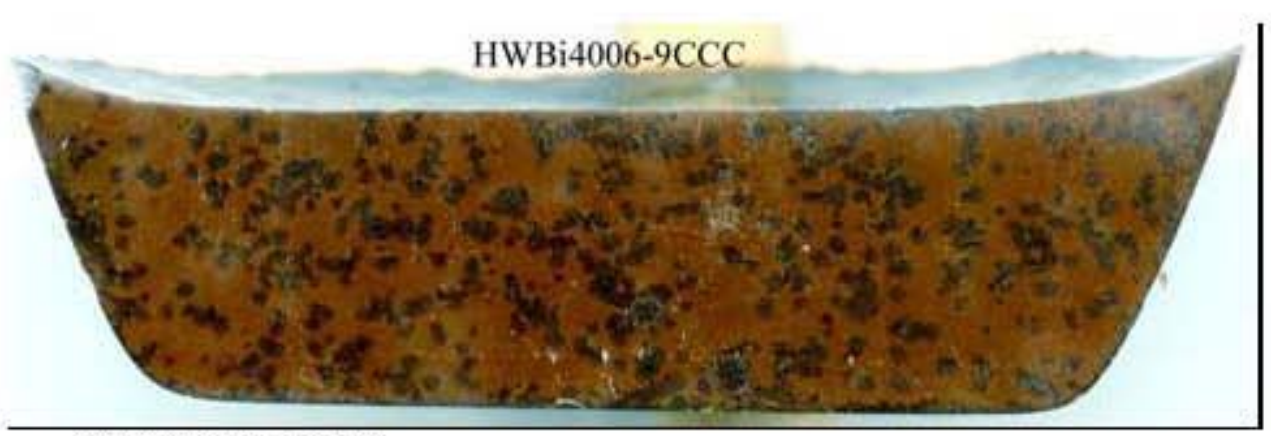

HWBi4006-9CCC

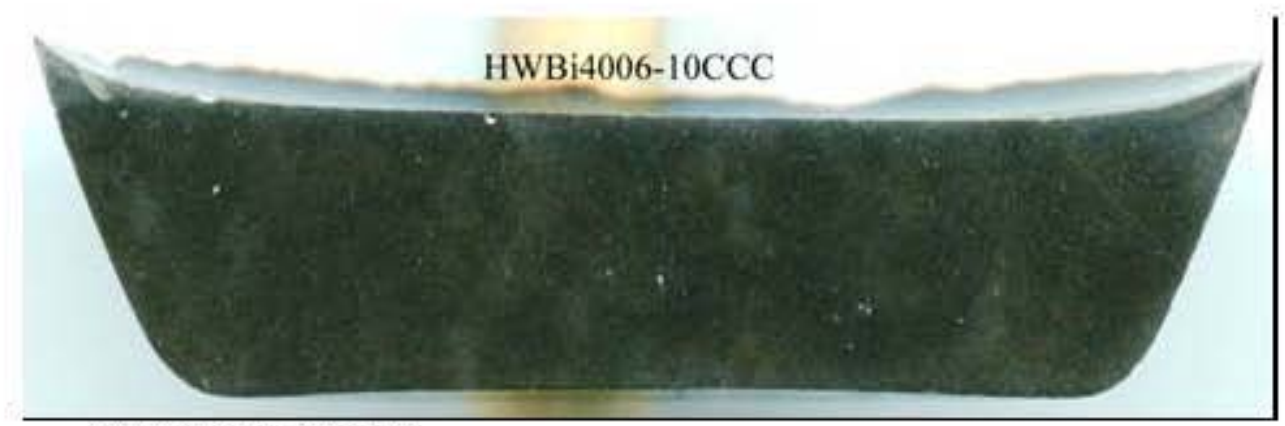

HWBi4006-10CCC

Figure 9. Cross sections of glass CCC samples of Waste Batch 4006 (continued). 


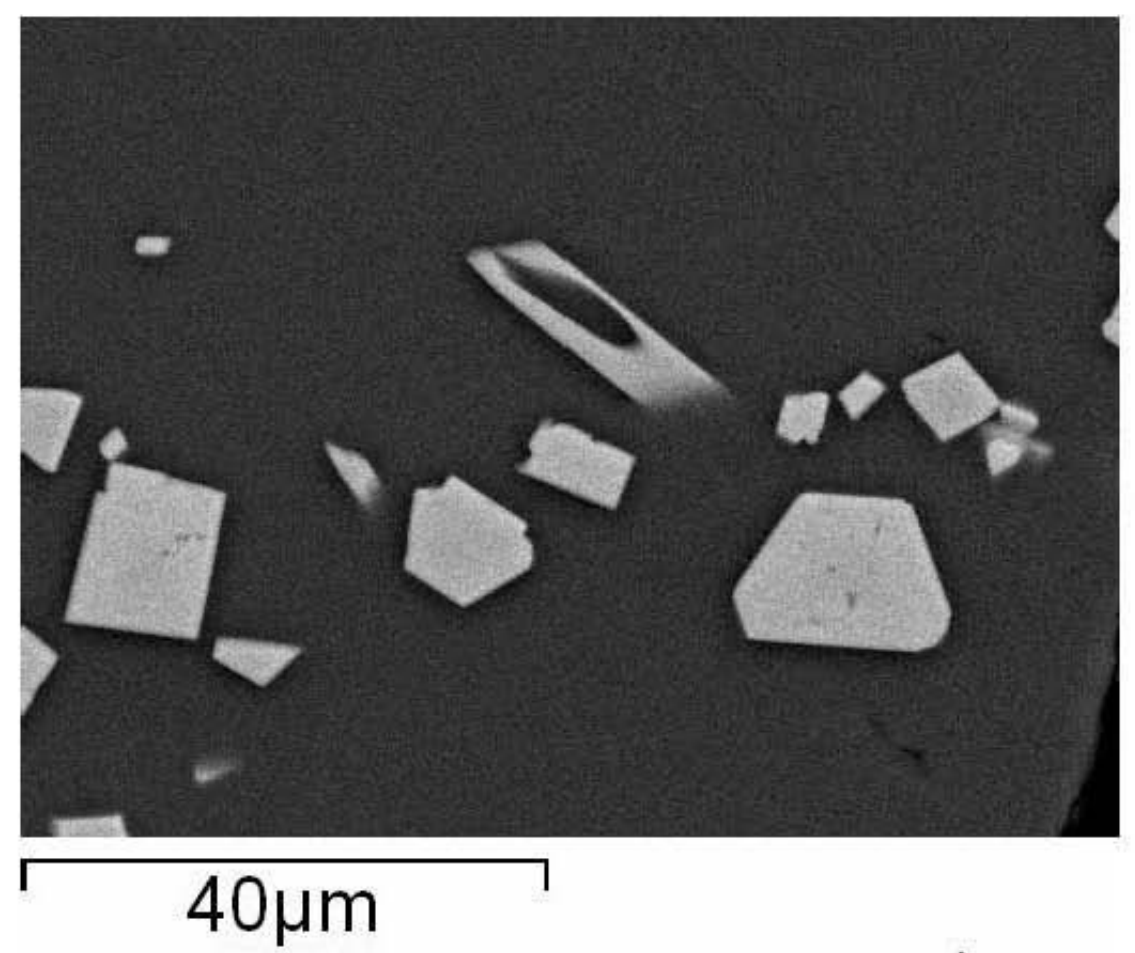

Figure 10a. SEM image of $\mathrm{HLWBi} 4006-6$ heat treated at $950^{\circ} \mathrm{C}(\mathrm{Cr}-\mathrm{Fe}-\mathrm{Mn}-\mathrm{Ni}$ Spinel).
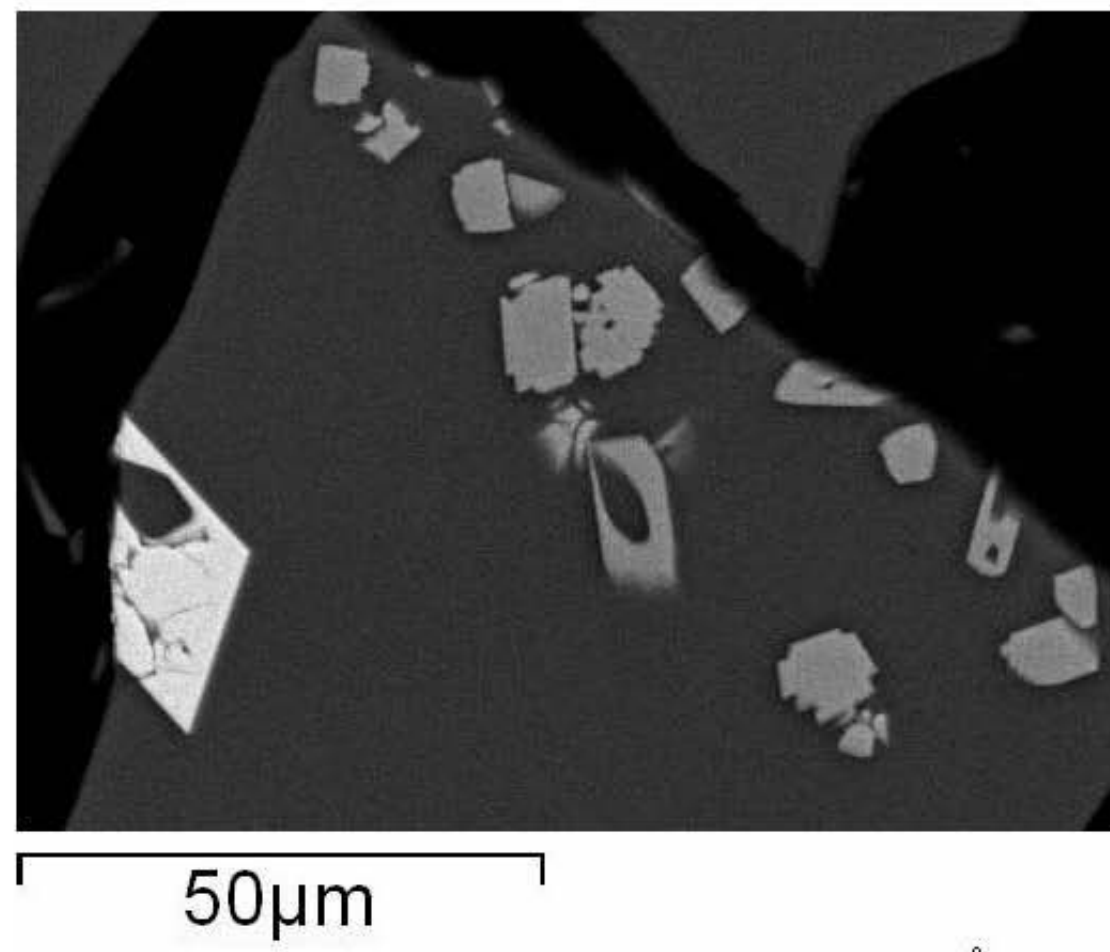

Figure 10b. SEM image of $\mathrm{HLWBi4006}-6$ heat treated at $900^{\circ} \mathrm{C}$ (grey phase: Cr-Fe-Mn-Ni spinel; bright phase on the left side: La-phosphate). 


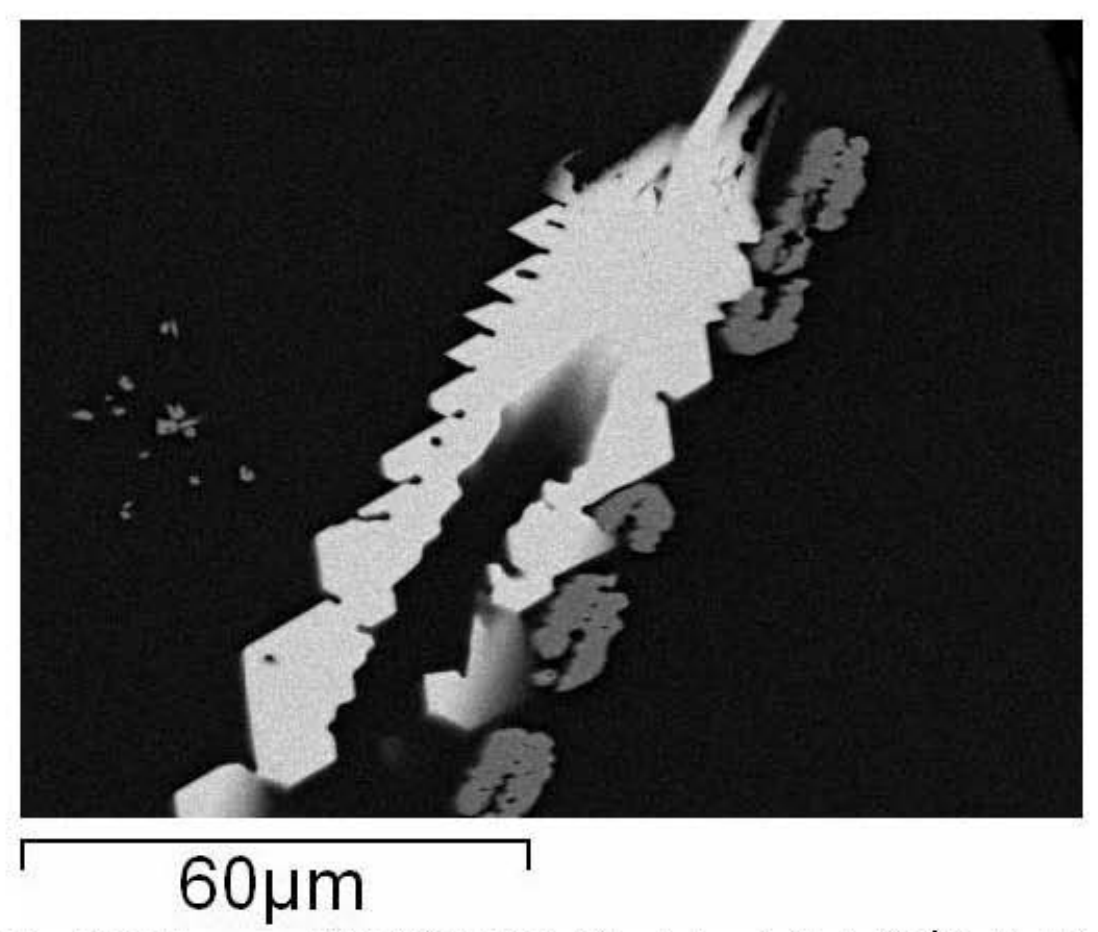

Figure 10c. SEM image of HLWBi4006-6 heat treated at $850^{\circ} \mathrm{C}$ (bright phase: La-phosphate; grey phase: Cr-Fe-Mn-Ni spinel).

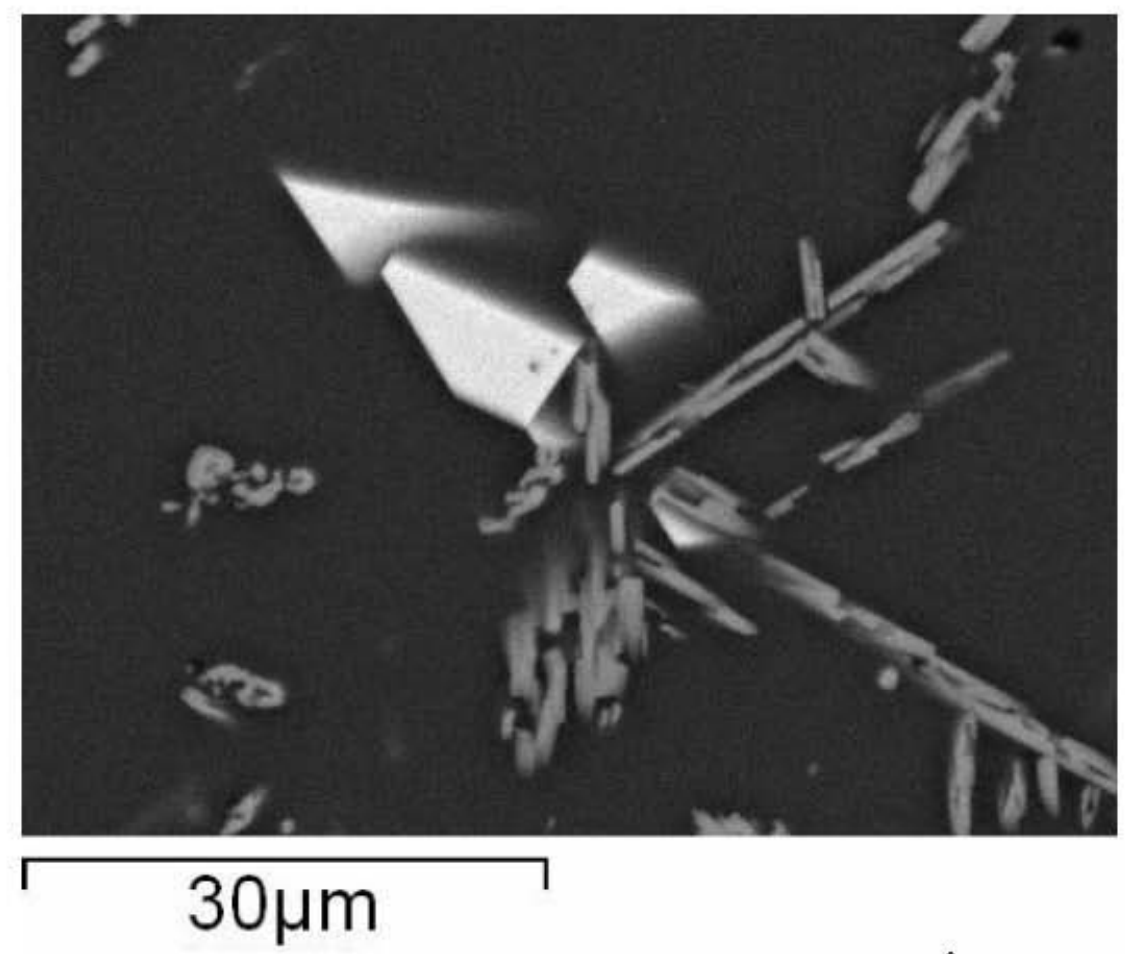

Figure 10d. SEM image of $\mathrm{HLWBi4006-6}$ heat treated at $800^{\circ} \mathrm{C}$ (bright an gular phase near center: La-phosphate; grey platelets: Ni-rich spinel with $\mathrm{Cr}, \mathrm{Fe}$ and $\mathrm{Mn}$ ). 


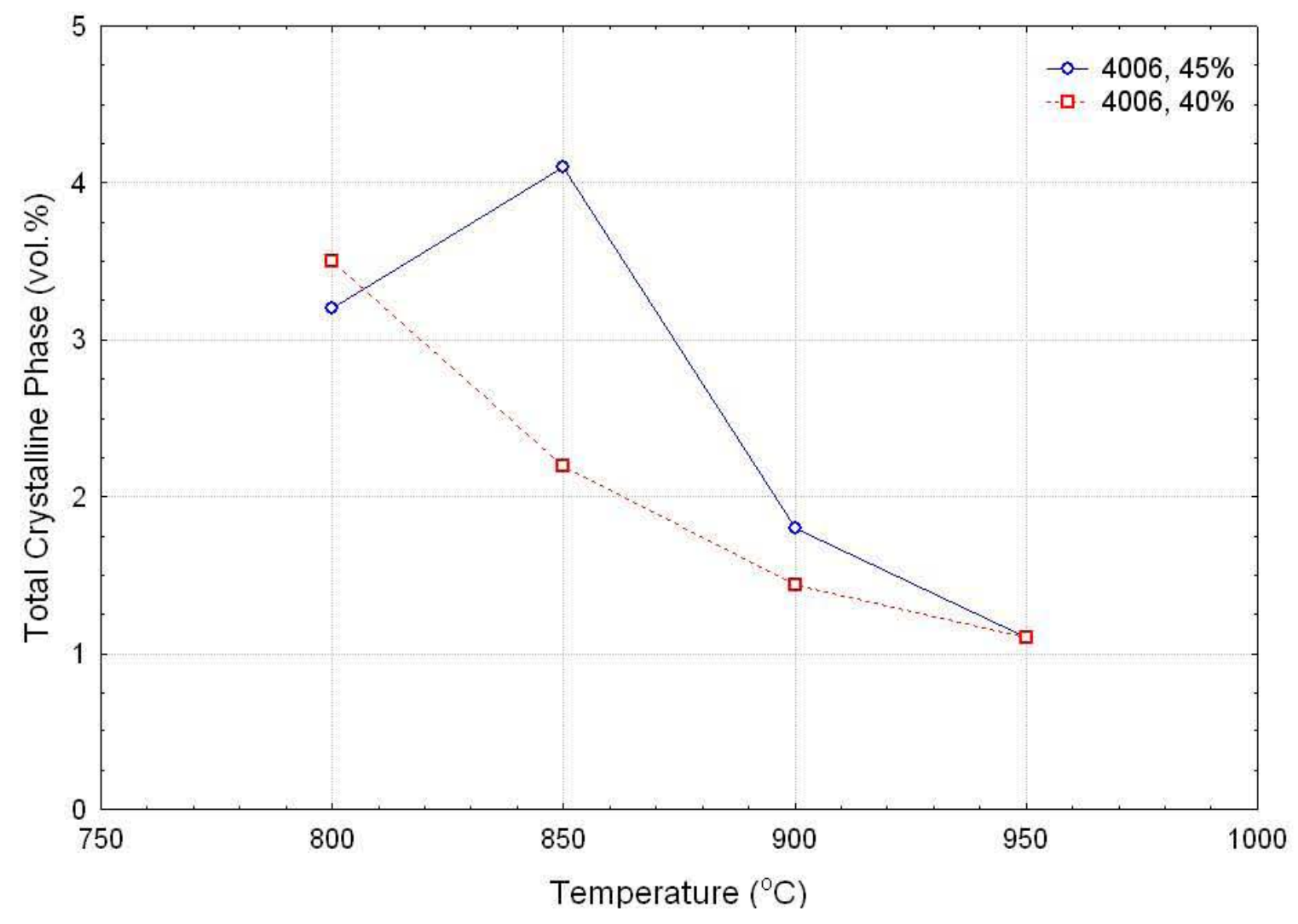

Figure 11. Total amount of crystalline phases (vol\%) after isothermal heat treatment of $\mathrm{HWBi4006-4} \mathrm{(45} \mathrm{wt \%} \mathrm{waste} \mathrm{loading,} \mathrm{blue} \mathrm{open} \mathrm{circles)} \mathrm{and}$ HWBi4006-6 (40 wt\% waste loading, red open squares). 


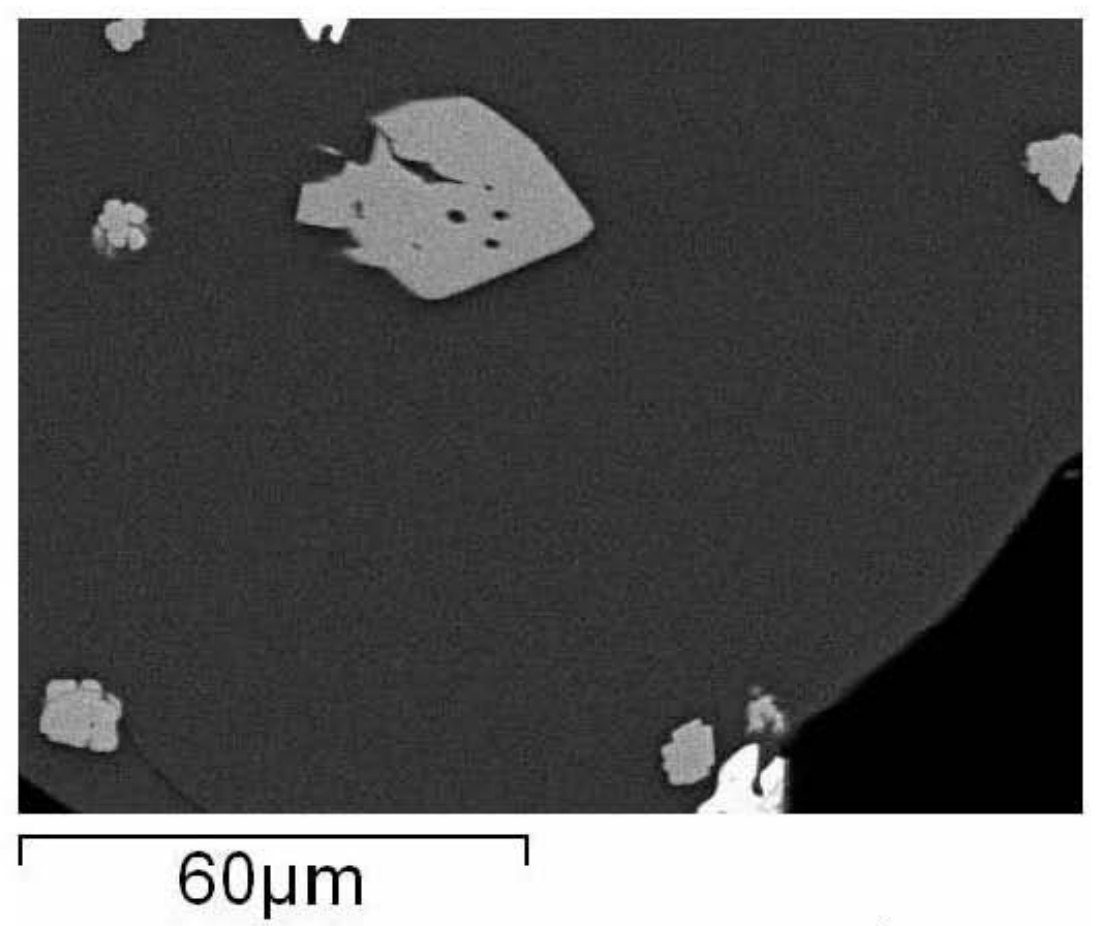

Figure 12a. SEM image of HLWBi4006-7 heat treated at $950^{\circ} \mathrm{C}$ (bright phase near bottom and top: La-phosphate; grey phase: Cr-Fe-Mn-Ni spinel with $\mathrm{Al}$ ).

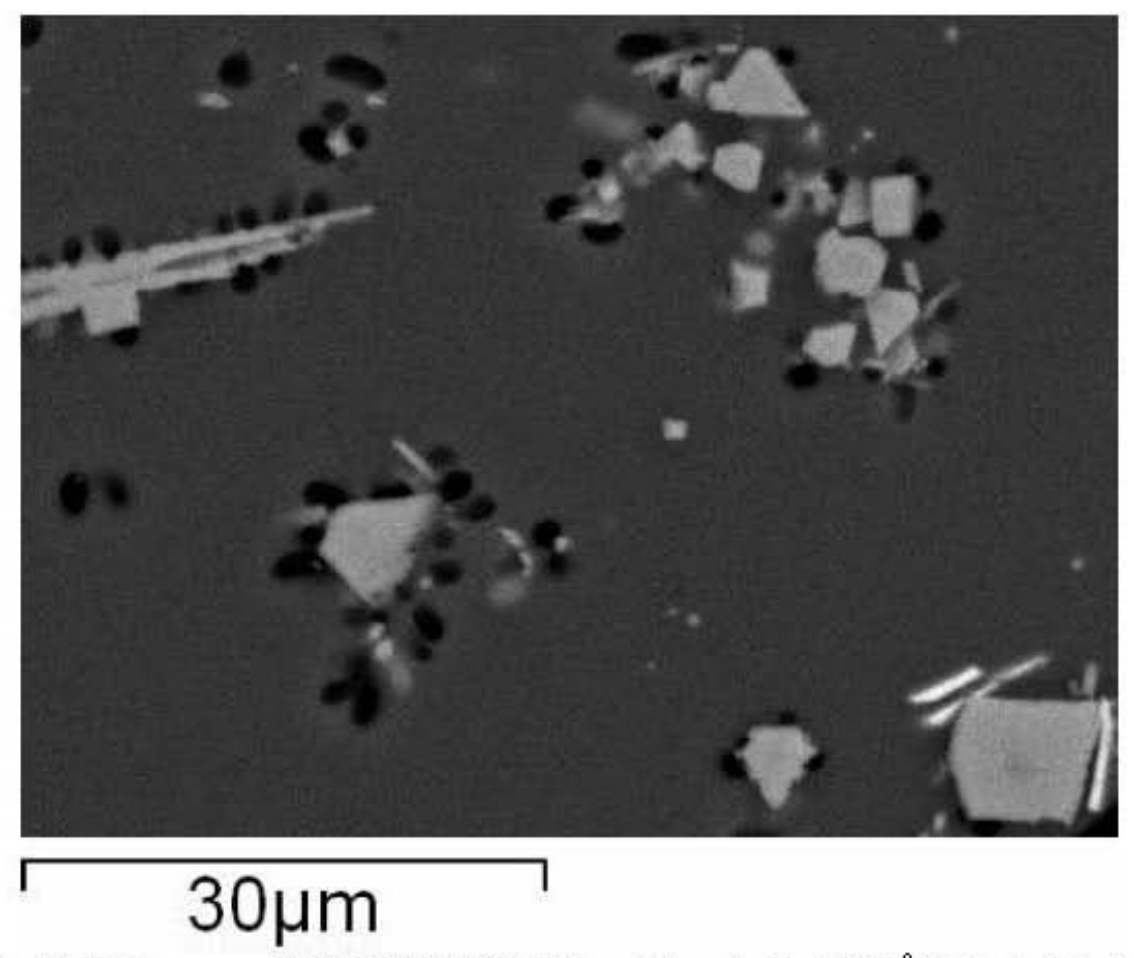

Figure 12b. SEM im age of $\mathrm{HLWBi4006-7}$ heat treated at $800^{\circ} \mathrm{C}$ (bright platelet near bottom right corner: La-phosphate; Grey phase: Cr-Fe-Mn-Ni spinel with considerable am ount of $\mathrm{Al}$; black globular shapes: Voids probably due to dissolution of $\mathrm{Na}$-Ca phosphate during sample polishing). 


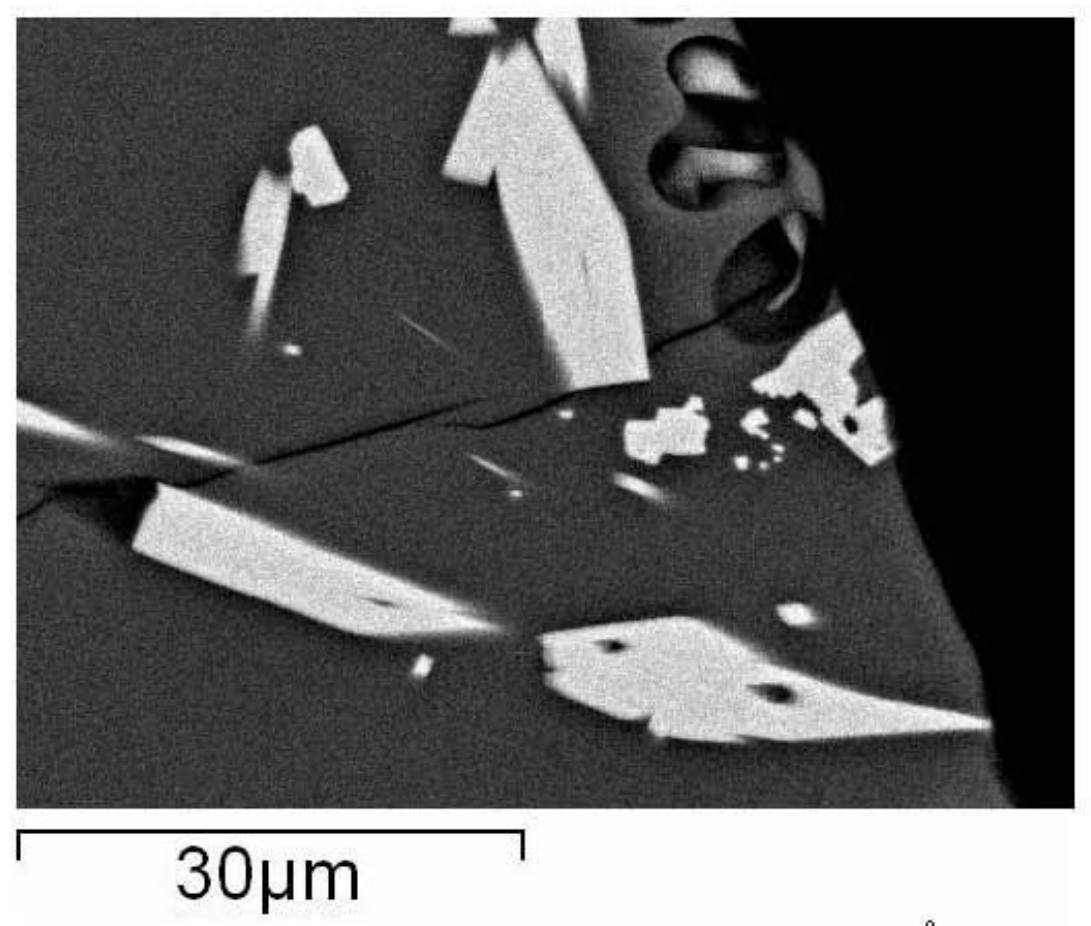

Figure 13a. SEM image of HLWBi4006-4 heat treated at $950^{\circ} \mathrm{C}$ (bright tabular phase: $\mathrm{Ni}-\mathrm{Cr}$ spin el with $\mathrm{Mn}$ and $\mathrm{Fe}$; globular regions along the boundary between dark grey (glass) and black (epoxy) area: Voids and remnants of Na-Ca phosphate partially dissolved during sample polishing).

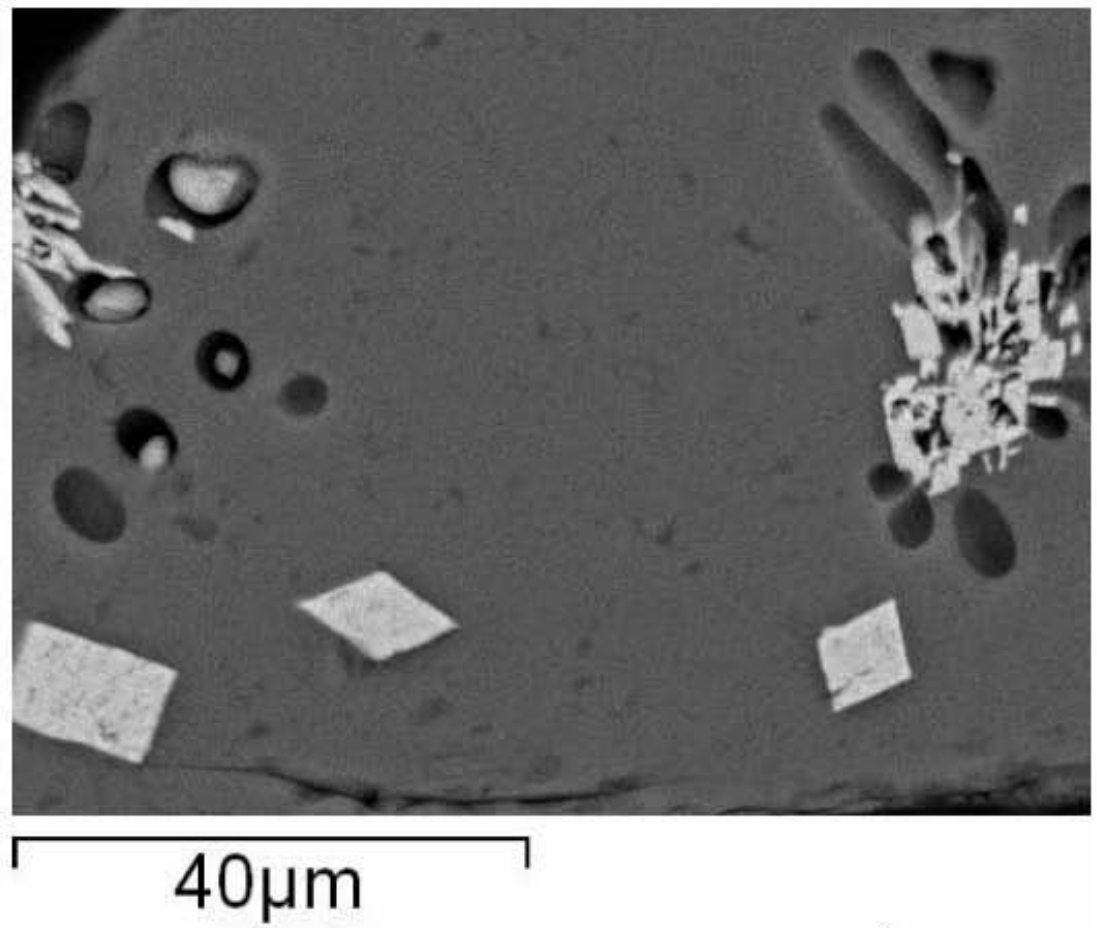

Figure 13b. SEM im age of HLWBi4006-4 heat treated at $900^{\circ} \mathrm{C}$ (bright ph ase: Ni-Cr spinel with $\mathrm{Mn}$ and $\mathrm{Fe}$; dark grey globular shapes: Voids and remnants of $\mathrm{Na}$-Ca phosphate with La, partially dissolved during sample polishing). 


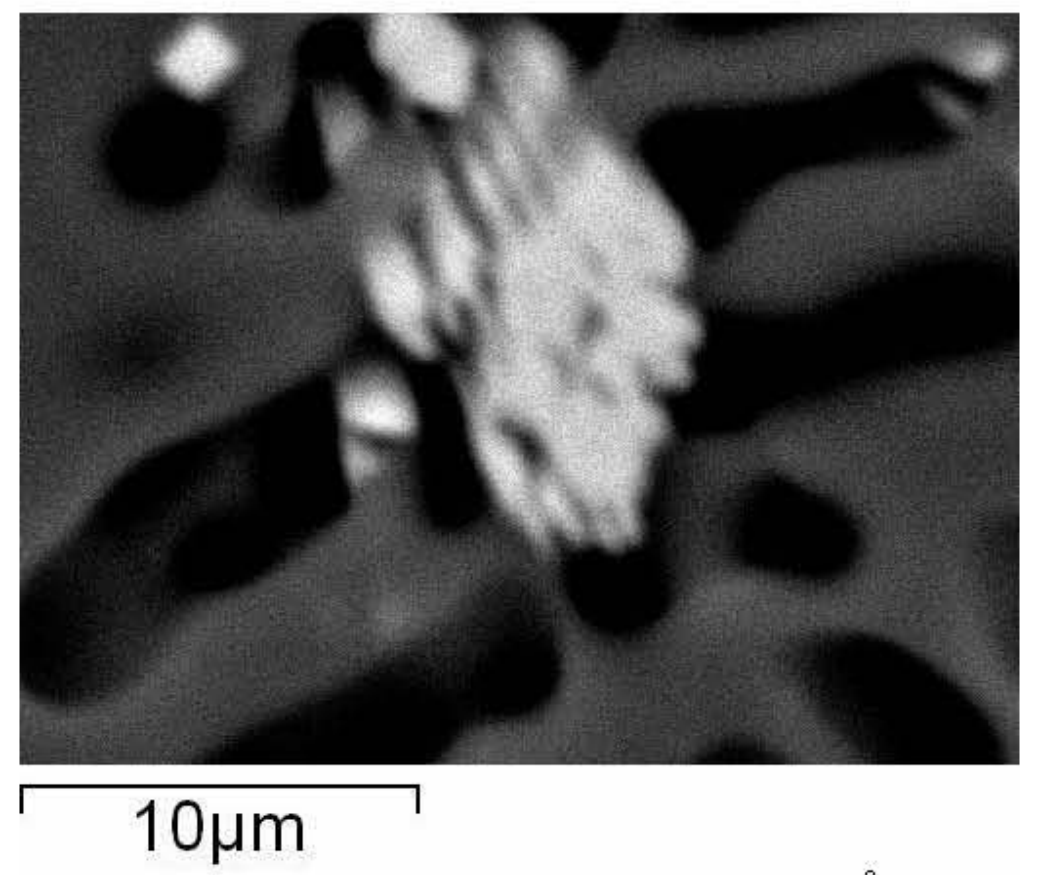

Figure 13c. SEM image of HLWBi4006-4 heat treated at $850^{\circ} \mathrm{C}$ (bright phase near center: Ni-Cr spinel with $\mathrm{Mn}$ and Fe; black globular regions: Probably voids due to dissolution of $\mathrm{Na}$-Ca phosphate during sample polishing).

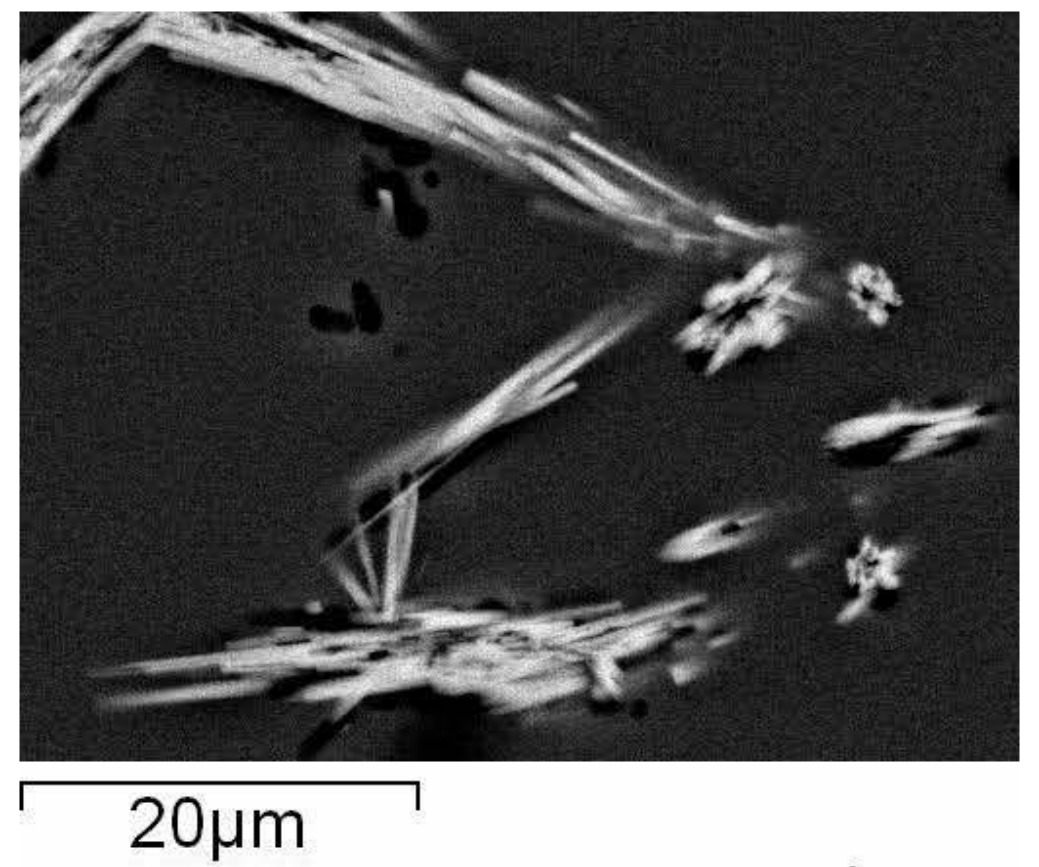

Figure 13d. SEM image of HLWBi4006-4 heat treated at $800^{\circ} \mathrm{C}$ (bright platelet: NiMn spinel with $\mathrm{Cr}$ and $\mathrm{Fe}$; black globular regions near center: Voids and remnants of $\mathrm{Na}-\mathrm{Ca}$ phosphate partially dissolved during sample polishing). 